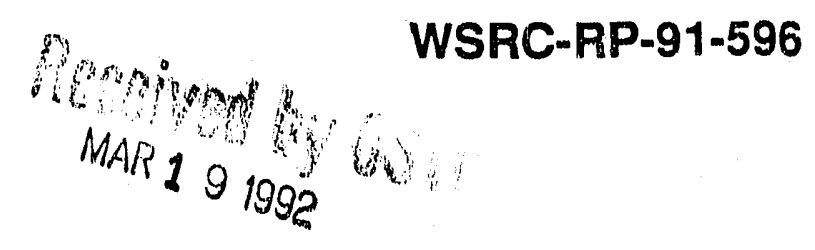

\title{
SAVANNAH RIVER SITE'S SITE SPECIFIC PLAN
}

\section{ENVIRONMENTAL RESTORATION AND WASTE MANAGEMENT FISCAL YEAR 1992}

August 1, 1991

Westinghouse Savarinah River Company Savannah River Site Alken, SC 29808

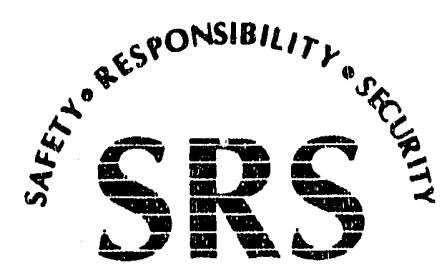


This report was prepared as an account of work sponsored by an agency of the United States Government. Neither the United States Government nor any agency thereof, nor any of their employees, makes any warranty, express or implied, or assumes any legal liability or responsibility for the accuracy, completeness, or usefulness of any information, apparatus, product, or process disclosed, or represents that its use would not infringe privately owned rights. Reference herein to any specific commercial product, process, or service by trade name, trademark, manufacturer, or otherwise does not necessarily constitute or imply its endorsement, recommendation, or favoring by the United States Government or any agency thereof. The views and opinions of authors expressed herein do not necessarily state or reflect those of the United States Government or any agency thereof.

\section{SAVANNAH RIVER SITE'S SITE SPECIFIC PLAN}

\section{ENVIRONMENTAL RESTORATION AND WASTE MANAGEMENT FISCAL YEAR 1992}

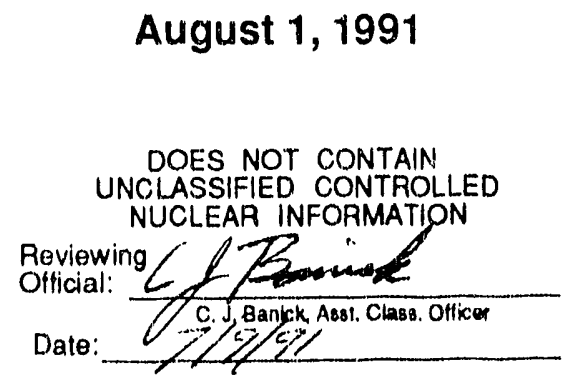




\section{CONTENTS}

Summary

Page

Section 1.0 Introduction 1

$1.1 \quad$ Purpose and Scope 1

1.2 The Five-Year Plan 3

Section 2.0 Description of Organizations, Facilities, and Missions 1

$2.1 \quad$ Mission

$2.2 \quad$ Organizations

2.2.1 Department of Energy-Savannah River (DOE-SR)

2.2.2 Contractor Organizations

2.3 Geographic Size

2.4 Locations and Descriptions of Installations

2.5 Compliance Status and Plans

2.5.1 Federal Statutes

2.5.2 State Regulations 15

2.5.3 Consent Orders and Agreements 18

Section 3.0 Primary Site-Specific Objectives by Program 1

3.1 Corrective Activities

3.1.1 Introduction

3.1.2 Description of Activities

3.2 Environmental Restoration

3.2.1 Introduction

3.2.2 Description of Activities

3.3 Waste Management Operations

3.3.1 Introduction

3.3.2 Description of Activities

3.3.2.1 Power

3.3.2.2 Reactor Materials 9

3.3.2.3 Reactors 12

$\begin{array}{ll}3.3 .2 .4 & \text { Separations } \\ 3.3 .2 .5 & 12\end{array}$

$\begin{array}{ll}3.3 .2 .5 & \text { Tritium Facility } \\ 3.3 .2 .6 & 12\end{array}$

3.3.2.6 Waste Management 13

3.3.2.6.1 High-Level Waste Management 13

3.3.2.6.2 Low-Level Solid Waste Management 17

3.3.2.6.3 Transuranic Waste Management 23

3.3.2.6.4 Hazardous Waste Management 26

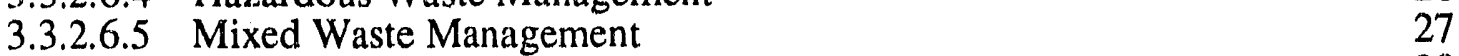

$\begin{array}{lll}3.3 .2 .6 .6 & \text { Sanitary Waste Management } & 28\end{array}$ 
Section 3.0 Primary Site-Specific Objectives by Program (Contd)

3.3.2.7 Defense Waste Processing Facility

3.3.2.7.1 Vitrification

3.3.2.7.2 Saltstone

29

3.3.2.8 Savannah River Laboratory

3.3.2.8.1 Low-Level Waste

3.3.2.8.2 High-Level Waste

3.3.2.8.3 Low-Level Mixed Waste

3.3.2.8.4 Sanitary Waste

3.3.2.8.5 Hazardous Waste

3.3.2.8.6 Transuranic Waste

3.3.2.8.7 Other

3.4 Technology Development

3.4.1 Introduction

3.4.2 Description of Activities

3.4.2.1 Waste Retrieval and Waste Processing

3.4.2.2 Integrated Demonstrations

3.4.2.3 Administrative Support and Planning

3.4.2.4 Education

Section 4.0 Major Accomplishments

4.1 Corrective Activities

4.2 Environmental Restoration

4.3 Waste Management Operations

4.3.1 Power

4.3.2 Reactor Materials

4.3.3 Reactors

4.3.4 Separations

4.3.5 Savannah River Laboratory

4.3.6 Tritium Department

4.3.7 Waste Management

4.3.8 Defense Waste Processing Facility

4.4 Technology Development

Section 5.0 Funding Summary Description 


\section{LIST OF TABLES}

2.1 Letter/Number Designations and Functions of Site Installations

5.1 Savannah River Site Funding Summary FY 1991-1997

6.1 Milestones

\section{LIST OF FIGURES}

2.1 Materials Flow Diagram

2.2 DOE-SR Organization Chart

2.3 WSRC Organization Chart

2.4 Regional Location of SRS

2.5 Installation Sites in the SRS

Savannah River Site Waste Site Closure Pathway

3.2 Conceptual Plan for Pretreatment Process

3.5 Savannah River Site Low-Level and Intermediate-Level

3.6 Solid Waste Disposal Facility, E Area

3.10 Nonradioactive Nonhazardous Waste Management Plan 


\section{SUMMARY}

\section{Introduction}

The Savannah River Site's Site Specific Plan (SSP) is produced annually to define sitewide environmental restoration and waste management activities identified by the Department of Energy (DOE) Environmental Restoration and Waste Management Five-Year Plan (FYP).

The FYP describes the environmental restoration and waste management (ER/WM) planning process, communicates ER/WM's philosophy and overall strategy for achieving its compliance and cleanup goals, summarizes multi-year program plans and assesses progress made during the previous year. The FYP goal is to ensure that risks to human health and safety and to the environment posed by the Department's past, present, and future operations are either eliminated or reduced to safer levels by the year 2019.

The SSP applies the overall strategic goals and commitments of the FYP, incorporating site-specific and local public considerations. It will address accomplishments since the FY 1990 plan, document planned activities focused on the upcoming fiscal year (FY 1992) and discuss milestones and objectives based on restricted and nonrestricted budget conditions for FY 1993-1997.

The SSP is the primary means of demonstrating the relationship of local cleanup and compliance activities to broad environmental goals set forth in the FYP. The SSP provides an important channel for conveying information to regulators, the public, special interest groups, and other DOE organizations.

This summary will briefly review the site's facilities and missiuns, current and future program objectives, major accomplishments, funding levels, and major nilestones for the five-year period.

\section{Description of Facilities and Missions}

The Savannah River Site (SRS) is a key installation for nuclear materials production and research for the DOE. This unique industrial complex covers 198,334 acres, or 325 square miles, encompassing parts of three counties, Aiken, Barnwell, and Allendale, in western South Carolina bordering the Savannah River. The SRS comprises 18 production, production support, service, research and development, and waste management areas. The primary areas of SRS are production facilities. They include a fuel and target fabrication facility, five nuclear reactors, two chemical separations plants, a tritium processing facility, a defense waste processing facility, a heavy water rework plant, a uranium fuel processing facility, and the Savannah River Laboratory (SRL).

Processing useful nuclear materials produces byproducts, which include radioactive waste, hazardous waste, and a combination of the two, mixed waste. Because some of these wastes remain radioactive or hazardous for many years, they must be treated, stored, and disposed of safely. Improved technical know-how and a reordering of DOE's and the nation's priorities have resulted in programs and facilities designed to provide greater 
protection to human health and the environment. However, past practices resulted in contamination to soil and groundwater.

Specific areas of concern regarding contamination are hazardous waste management units, which consist primarily of seepage basins and rubble pits; sites contaminated by unplanned releases of hazardous liquids; existence of trichloroethylene in groundwater near the Savannah River; and effluent discharges to the Savannah River Swamp.

A top priority of the SRS is compliance with all applicable federal and South Carolina environmental regulations and U. S. DOE Orders. The Environmental Protection Agency (EPA) monitors all federal regulations. Chief among site compliance activities are the Resource Conservation and Recovery Act (RCRA) and the Comprehensive Environmental Response, Compensation and Liability Act (CERCLA). The South Carolina Department of Health and Environmental Control (SCDHEC) monitors all state regulations and oversees some federal regulations.

The Federal Facility Agreement (FFA), a three-party agreement between the EPA, SCDHEC and DOE, is currently in draft form and is due to be released upon approval by DOE-HQ for public comment. The purpose of the FFA is to: 1) ensure that environmental impacts of past and present activities are investigated, and appropriate action is taken to protect public health, welfare, and the environment; 2) establish a basis for determining that DOE has completed remedial actions in accordance with environmental laws; and 3) ensure that the public is informed and involved in the process.

\section{Primary Program Objectives and Accomplishments}

The primary programs addressed in the SSP are Corrective Activities, Waste Management, Environmental Restoration, and Technology Development.

\section{Corrective Activities Program}

Corrective activities are those activities neerled to bring active and standby facilities, currently out of compliance with applicable local, state, and federal requirements, and internal DOE requirements into compliance. Corrective activities are grouped into three categories: air, water, and solid waste.

The only major corrective activity underway at SRS involves construction of a mechanical draft cooling tower for thermal mitigation of K-Reactor effluent. Because Corrective Activities must be completed in a timely and effective manner, they are generally accomplished using existing technologies.

One majo: activity accomplishment was the elimination of a power house wastewater effluent discharge point. The wastewater is now collected in a tank and transported to an ash basin for disposal.

\section{Environmental Restoration (ER) Program}

'The ER Department is responsible for all aspects of assessment and cleanup of facilities and sites that are no longer a part of active operations but are contaminated with various 
quantities of transuranic, low-level, hazardous, or mixed waste materials. ER is also responsible for inactive waste sites which are nonhazardous and nonradioactive. The WSRC-ER Department was formed at the SRS in 1991 to consolidate all ER activities. It consists of two distinct activities: Remedial Actions and Decontamination and Decommissioning (D\&D). The Department's goal is to ensure that risks to human health and safety and to the environment posed by DOE's past, present, and future operations are either eliminated or reduced to prescribed, safe levels.

Remedial Action includes site identification, assessment and inspection; characterization, analysis of alternatives and remedy selection; cleanup and closure; and compliance monitoring. Although remedial actions may deal with surface water contamination or with tanks, buildings, or structures, most remedial action activities are now directed toward cleanup of contaminated soil and groundwater.

$D \& D$ is the safe caretaking of inactive nuclear facilities until they are decontaminated, followed by entombment, dismantling and removal, or conversion to another use. D\&D tasks include surveillance and maintenance, assessment and characterization, environmental review, engineering, operations, and closeout.

ER activities are regulated by RCRA, CERCLA, DOE Orders 5400.3 and 5400.4 , and a variety of state requirements.

ER has undertaken an active program and realized many accomplishments. One hundred and seventeen waste sites at SRS have been evaluated and scheduled for detailed investigation and characterization. Another 302 sites have been identified for preliminary evaluation that could lead to more detailed studies.

The M-Area Settling Basin, contaminated with solvents and metals from past operations, has been closed. Three of the seven F- and H-Area seepage basins were closed, and the four remaining basins will be closed later this year. The Mixed Waste Management Facility, contaminated with low-level radioactive and hazardous wastes, was closed in 1990. These RCRA closures were completed in accordance with SCDHEC regulations, a first for the site.

Other major closures underway and anticipated for completion during the upcoming year are the Metallurgical Laboratory Basin, used for disposal of wastewater containing metals and organic solvent, and the 105-C Process Tank wastewater and sludge.

\section{Waste Management Program}

The primary purpose of the Waste Management Department is to manage, account for, and dispose of all types of DOE waste in a safe and environmentally sound manner. A fundamental goal of Waste Management Operations is to achieve real reductions in the volume and toxicity of the waste. The waste sategories at SRS are radioactive, hazardous, mixed, and sanitary.

The Waste Management Program at SRS is extensive and comprehensive, covering all facets of site operations. One hundred thirty-seven waste management operations and research and development activities were identified for the past fiscal year and account for 87 percent of the budget identified in the SSP. 
The SRS waste management objectives are to comply with applicable federal and state regulations, DOE Orders, and WSRC policies, to minimize effects on the environment, minimize the generation of waste, and to the extent possible, contain waste handling, treatment, storage, and disposal within the site. The SSP presents the strategy to carry out these objectives.

Accomplishments occurred in many areas of waste management operations during the past year. Several test program milestones in the Defense Waste Processing Facility were successfully completed. The power facility ash scrubber water system was redesigned to effectively eliminate high levels of arsenic. A new process was implemented to treat the separated supernate layer in the Interim Treatment/Storage Facility Tanks that will reduce the volume of material requiring treatment, stabilization, and subsequent storage. A formal Waste Minimization Program achieved excellent results in several waste operation areas.

SRL's research and development activities center on support for site waste management, production operations, solution of production technical problems, and enhancement of existing production processes. The emphasis is on development and demonstration of technology for waste management operations. Primary efforts are currently being undertaken in the areas of high-level waste decontamination, high-level waste transfer, low-level liquid treatment, waste incineration technology, plutonium recovery, transuranic waste support, high-level waste tank farm support, SRL model waste, salt disposal, new low-level waste disposal systems, waste disposal technology, waste site closure support, decontamination technology, waste solidification, and waste minimization.

\section{Technology Development Program}

The Office of Technology Development (OTD) was formed by DOE to establish and maintain an aggressive program for applied research and development, to resolve major technical issues and rapidly advance, beyond current technologies, for environmental restoration and waste operations. Within the OTD, the Research and Development Program provides the technology base necessary to determine the technical, economic, and regulatory justification to transfer technologies to other divisions.

A variety of accomplishments have been realized in the technology development area. Developed by researchers in SRL, a new drilling technique, utilizing rizontai wells, is being used to clean up contaminated groundwater and to prevent contamination from spreading. This pilot well system was installed at the site's M Area where the groundwater has been contaminated. Other major activities include waste retrieval and processing, administrative support, and planning, including robotics and educational outreach activities.

Significant progress has been made in the area of technology development. Evaluation of several site operations programs is complete. Characterization and development of other programs are underway. 


\section{Cost}

Waste Management and Environmental Restoration projected costs will total over $\$ 612$ million in FY 1991 and over \$558 million in FY 1992, based on the President's budget. The following table shows defense and nondefense costs over the planning period.The FYP starts with FY 1991 execution and establishes the FY 1992 amended President's budget and forecasts budget projections from FY 1993 through FY 1997 using Preliminary Unvalidated Case (PUC) and Validated Target i.evel (VTL) scenarios.

\section{Preliminary Unvalidated Case}

PUC represents a preliminary estimate of funding: to ensure protection of the public and worker health and safety, to carry out the agreements entered into by DOE, to ensure compliance with applicable environmental requirements, and to implement other desired improvements.

\section{Validated Target Level}

VTL provides a ten percent annual increase for the defense-related Environinental Monitoring (EM) Program. This growth rate far exceeds that of any other defense-funded program within DOE. The program grows at ten percent per year even in the context of declining statutory caps for the overall defense category which were insisted upon by Congress.

Under this case, consistent with the EM prioritization philosophy, priority 1 activities would be funded at the largest percentage of the PUC. Priority 4 activities would receive the lowest percentage of the field-office requested funding.

Nuither the PUC nor the VTL necessarily reflects the actual amount of money that will be allocated to the EM Program between FY 1993 and FY 1997. Actual funding will depend upon further priority setting in the context of the annual budget and appropriations prncess. 
Funding Summary (Thousands of Dollars)

FY 1991

EY 1992

Corrective Activities

Defense

47,600

Environmental Restoration

Assessment

Defense

Nondefense

Subtotal

19,850

19,714

$\overline{19.850}$

20.044

Cleanup

Defense

Nondefense

Subtotal

27,650

35,216

Total

$\overline{27.650}$

$\overline{35.216}$

47.500

55.260

Waste Operations

Defense

Nondefense

Total

508,536

491,325

508.536

$\overline{491.325}$

Technology Development

9.215

12.190

Grand total

612,851

558,775 


\section{Milestones}

The following major milestones were identified in the PUC as presented in the FYP Activity Data Sheets. These milestones may change depending on final program guidance from DOE-HQ.

\section{Environmental Restoration}

FY 1992 milestones include:

- Completion of railroad crosstie disposal

- Closure of acid/caustic basins

- Submittal of 11 work plans to EPA

- Start of D\&D Studies

- Continuation of groundwater remediation efforts of A/M Areas, Sanitary Landfill, MW/MF, F/H Areas, and TNX

Major milestones to be established for FY 1993-1997 include:

- Closure of SRL seepage basins and the new TNX seepage basin

- Closure of 22 solvent tanks and 4 underground fuel storage tanks

- Closure of the Sanitary Landfill

\section{Waste Management}

FY 1992 milestones include:

- Recovery of 2.5-million gallons of space in F- and H-Area Evaporators

- Achievement of 95 percent certification of newly generated drummed TRU waste

- Startup of hazardous waste/mixed waste (HW/MW) Vault Construction

- Begin In-Tank Precipitation

Major milestones for FY 1993-1997 include:

- Startup of Consolidated Incinerator Facility (CIF)

- Startup of HW/MW Vault Construction 
Corrective Activities

Major mileitone for FY 1993 includes:

- Completion of K-Reactor Cooling Tower

Defense Waste Processing Facility (DWPF)

Major milestones for FY 1993-1995 include:

- Hot Startup of DWPF

- Startup of Y-Area Radioactive Operations

\section{Technology Develogment Division}

Major milestones for FY 1992 include:

- Hazardous and Mixed Waste Treatment Technology Development

- Savannah River Laboratory TRU Waste Treatment

- Aqueous Detritiation Technology Development

- TCE Biodegradation Demonstration Technology Developmextat

- Integrated Demonstration for Cleanup of Organics in Soils and at Non-Arid Sites; Phase 2 Bioremediation Tasks

- Savannah River Site Integrated Demonstration; Directional Drilling and Characterization

- Integrated Demonstration for Cleanup of Organics in Soils and at Non-Arid Sites; Offgas Treatment 


\section{CONTENTS}

\section{Section 1.0 Introduction}

\section{Page}

1.1 Purpose and Scope

1.2 The Five-Year Plan 


\subsection{INTRODUCTION}

\subsection{Purpose And Scope}

This Site Specific Plan (SSP) has been prepared by the Savannah River Site (SRS) in order to show the Environmental Restoration and Waste Management activities that were identified during the preparation of the Department of Energy-Headquarters (DOE-HQ) Environmental Restoration and Waste Management Five-Year Plan (FYP) for FY 19921996. The SSP has been prepared in accordance with guidance received from DOE-HQ. DOE-SR is accountable to DOE-HQ for the implementation of this plan.

The purpose of the SSP is to develop a baseline for policy, budget, and schedules for the DOE Elivironmental Restoration and Waste Management activities. The plan explains accomplishments since the Fiscal Year (FY) 1990 plan, demonstrates how present and future activities are prioritized, identifies currently funded activities and activities that are planned to be funded in the upcoming fiscal year, and describes future activities that SRS is considering. The SSP is based on the information in the Activity Data Sheets (ADSs) and Technical Task Sheets which provide the basis against which technical performance, cost, and schedule will be measured.

The ability to react to change in priorities or adapt to new environmental/reg:ulatory re 4 uirements is an important concern in managing the SSP. Activities are planned in advance to anticipate possible roadblocks or unforeseen problems. The degree of uncertainty is reflected in the quality of the estimate by allowing for some conservatism. In the event a shift in resources is required to address a new concern(s), the flexibility exists to reflect this with the check and balance provided by DOE-HQ. Under all circumstances, all regulatory commitrients and/or environmental laws and regulations will be met by diverting resources as required. Funding required for federal or state compliance agreements and regulatory requirements will receive top priority in the budgetary decision making.

Some envirormental activities and oversite are outside the scope of the SSP and FYP and fall into the category referred to as the environmentai base. The environmental base activities include general site activities for monitoring and maintenance, compliance with air quality, groundwater, drinking water, surface water, and underground storage tanks. The environmental base also includes DOE and Westinghouse Savannah River Company personnel and their respective environmental programs. Other activities not included in the SSP and FYP are health protection, safety, and emergency preparedness programs.

The FYP goal is to provide cleanup at all DOE sites by the year 2019. The SSP demonstrates the direction that the site is taking toward meeting that goal. Quoting from the FYP are the following specific DOE goals and commitments:

- Complying with laws and regulations aimed at protecting human health and the environment. 
- Developing a national prioritization system for cleanup activities to be derived with state, tribal, and other public involvement.

- Containing known contamination at inactive sites and vigorously assessing the uncertain nature and extent of contamination at other sites to enable realistic planning, scheduling, and budgeting for cleanup.

- Supporting establishment of interagency agreements and fulfilling the requirements of compliance agreements already in place.

- Releasing, for scientific analysis, the health records of workers at DOE facilities and conducting public health risk assessments at plant sites for past, present, and future operations.

- Implementing programs to minimize current waste generation and future waste disposal requirements.

- Establishing an Applied Research and Development program involving university research capabilities, industry, national laboratories, and other federal agencies to deterrnine and prioritize research and development needs and pursue new and improved technologies for waste minimization and cleanup.

- Changing DOE culture to one of clear and open communication. DOE must listen to its critics and not contend that all is well or that the Department knows all the answers.

- Working diligently to achieve congressional support for the FYP's o'^رectives.

- Taking innovative steps to develop, motivate, and allocate the human resources needed to implement compliance and cleanup activities.

- Recognizing tribal sovereignty and treaty rights related to tribal and ceded lands.

- Continually examining environmental regulations to ensure that DOE's compliance actions effectively reduce risk to human health and the environment.

Many of these goals and commitments are included with the implementation of the SSP. By implementing the SSP, SRS is:

- Placing a high priority on laws and regulations to protect human health and the environment.

- Involving the South Carolina Department of Health and Environmental Control (SCDHEC) and Environmental Protection Agency (EPA) in FY 1992 on the prioritization of Environmental Restoration activities.

- Establishing interagency agreements with EPA and the SCDHEC on Land Disposal Restriction (LDR) waste and Comprehensive Environmental Response, Compensation, and Liability Act (CERCLA) cleanup. 
- Implementing a comprehensive waste minimization system for solid, hazardous, and mixed waste.

- Developing a public participation program for the SSP and other environmental activities.

Through the annual updates of the SSP, DOE and the operating contractor will continue to

- report its progress toward achieving compliance goals and will explain shanges in strategy due to public involvement, new policies, and funding.

\subsection{The Five-Year Plan}

The FYP reaffirms DOE's commitment to a 30-year goal of compliance with laws, regulations, and agreements aimed at protecting human health and the environment; consolidates DOE's planning for Environmental Restoration activities, Waste Operations activities (including Corrective Activities), and Technology Development activities; reports progress made toward achieving compliance goals; and explains changes in strategy due to new policies and external events.

The FYP for FY 1993-1997 covers four areas: Corrective Activities, Environmental Restoration, Waste Management Operations and Technology Development. Corrective activities are those activities necessary to bring active or standby facilities into compliance with local, state, and federal environmental regulations. Environmental Restoration activities include the assessment and cleanup of surplus facilities and inactive waste sites. A surplus facility is a facility that is not essential to the mission of the site. Waste Management Operaticns includes the treatment, storage, and disposal of wastes which are generated as a result of ongoing operations. T'echnology Development is research and development activities necessary for Environmental Restoration and Waste Management activities to progress in a more effective and efficient manner.

The FYP starts with FY 1991 execution, establishes the FY 1992 amended President's budget and forecasts budget projections from FY 1993 through FY 1997 using PUC and VTL scenarios explained in the "Summary." 


\section{CONTENTS}

Section 2.0 Description of Organizations, Facilities, and Missions 1

2.1. Mission

$2.2 \quad$ Organizations

2.2.1 Department of Energy-Savannah River (DOE-SR)

2.2.2 Contractor Organizations

$2.3 \quad$ Geographic Size

$2.4 \quad$ Locations and Descriptions of Installations

$2.5 \quad$ Compliance Status and Plans

2.5.1 Federal Statutes

2.5.2 State Regulations

2.5.3 Consent Orders and Agreements

Page

\section{LIST OF TABLES}

2.1 Letter/Number Designations and Functions of Site Installations

\section{LIST OF FIGURES}

2.1 Materials Flow Diagram

2.2 DOE-SR Organization Chart

2.3 WSRC Organization Chart

2.4

Regional Location of SRS

25

2.5 Installation Sites in the SRS 


\subsection{DESCRIPTION OF ORGANIZATIONS, FACILITIES, AND MISSIONS}

\subsection{Mission}

The mission of the SRS is to serve the national security interest of the United States by safely producing nuclear materials while protecting the employee and public health and the environment.

The SRS produces nuclear materials by manufacturing fuel and target components, irradiating the components in nuclear reactors, chemically extracting the desired nuclear materials from the irradiated fuel and targets, and separating radioactive waste from the desired materials. These radioactive wastes will be solidified in glass for final offsite geological disposal. Figure 2.1 is a simplified materials flow diagram of the site.

\subsection{Organizations}

\subsubsection{Department Of Energy-Savannah River (DOE-SR)}

The U. S. Department of Energy-Savannah River Field Office (DOE-SR) is responsible for coordinating, planning, and directing the operations at the Savannah River Site (SRS). The DOE-SR oversees the day-to-day operation of the facilities at SRS, reviews operating policies and procedures, performs appraisals, and conducts audits (see Figure 2.2).

The SSP is the responsibility of the DOE-SR. The DOE-SR directs the management and implementation of all Environmental Restoration, Waste Management, Corrective Activities and Technology Development activities in the plan; and reviews and checks the budget request for Congress to ensure that there is sufficient funding for the SRS to meet its schedules and milestones of the activities in the SSP. DOE-SR also reviews and approves all submittals related to environmental activities to agencies and organizations outside of the SRS.

Within the DOE-SR, the Environmental Restoration, Waste Management, Corrective Activities and Technology Development responsibilities for each organization are as follows:

- The Assistant Manager for Facility Operations (AMFO) organization has primary responsibility for the environrnental compliance, operation, and management of the SRS non-reactor facilities.

- The Assistant Manager for Environment, Safety, and Security (AMES\&S) organization is responsible for directing, planning, and coordinating all SRS work related to environmental protection, health protection, safety, and quality assurance. In addition, the AMES\&S organization is providing independent oversight for environmental protection, health protection, safety, and quality assurance to activities in the SSP. 
- The Assistant Manager for Engineering and Projects (AMEP) organization is responsible for engineering design and construction of the SRS facilities. It also has primary responsibility for the operation and management of all SRS Power Department facilities such as the powerhouses, sanitary treatment plants, and the Savannah River Laboratory (SRL).

- The Director of the Manufacturing Division, who reports to the AMFO, is primarily responsible for directing and managing the environmental compliance and operation of the Reactor Materials Facilities, Tritium Facility and Naval Fuels Facility.

- The Assistant Manager for Environmental Restoration and Waste Management (AMERWM) has the primary responsibility for directing all work associated with Environmental Restoration and Waste Management activities ard implementing and managing the SSP. The AMERWM is also responsible for coordinating the planning, tracking, and reporting of activities for the SSP.

The AMERWM will ensure the implementation of the SSP by:

- Providing technical oversight and direction to the contractor(s) for waste management planning and operations.

- Reviewing and approving all Environmental Restoration, Waste Management, and Technical Development reports and documents required by DOE-HQ or regulators.

- Coordinating the contractor(s) program/budget submission to DOF-HQ for the Environmental Restoration and Waste Management operations and Technical Development activities.

- Reviewing detail procedures, policies, and practices established by the contractor for compliance with DOE policy, and the safe and environmentally sound operation of the facilities.

- Annually updating the Waste Management plans for all Waste Management activities at SRS.

- Requiring the contractor(s) to perform monthly budget and status reports on all currently funded Waste Management and Environmental Restoration projects and Technical Development activities.

- The Director of the Environmental Restoration Division, reporting to the AMERWM, directs the efforts of the Environmental Restoration Branch and Environmental Compliance Program Management Branch. Responsibilities include planning, coordinating, and directing environmental programs for the Savannah River line and project activities, developing and implementing DOE-SR policies, and evaluating contractor's work. 

FACILITIES, AND MISSIONS

- The Director of the Waste Operations and Technical (WO\&T) Division, reporting to the AMERWM, plans, coordinates, and directs the overall SRS low-level, transuranic, mixed, and hazardous waste management programs and related technology development program. Other duties include technical support for Environmental, Safety and Health (ES\&H) Activities for all waste management programs. The Division serves as the primary point of contact with DOE-HQ for all activities associated with the SSP.

The principal areas of responsibility include:

- SRS Management Programs for low-level waste disposal, the Effluent Treatment Facility, the Consolidated Incinerator Facility, Sanitary Landfill Project, Waste Minimization, and the Transuranic Waste Storage and Processing Facility.

- Research and technology development activities in support of SRS, Environmental Restoration, and waste $n$ anagement programs.

- Technical Support in the area of Environmental, Safety, and Health and Quality Assurance for all waste management programs.

- The Director of the High-Level Waste (HLW) Division, reporting to the AMERWM, directs the efforts of the Defense Waste Processing Facility (DWPF) Branch, the DWPF Compliance Branch, and the HLW Tank Farm Branch. Responsibilities include startup and operation of the DWPF, Saitstone Facility, In-Tank Precipitation (ITP), and F- and H-Area HLW Tank Farms. This Division serves as the primary point of contact with DOE-HQ for all activities associated with HLW Operations at the DOE-SR Field Office.

- The Director of the Environmental Division (ED), reporting to the AMES\&S, oversees SRS compliance with federal and state environmental regulations and agreements and DOE environmental orders and policies; implements the National Environmental Policy Act (NEPA); provides advice and support to the Manager, DOE-SR, and to other DOESR Offices and Divisions on implementation of environmental requirements, environmental technology development, and natural resource management; and provides an overview of contractor quality performance of environmental requirements. The ED also coordinates all federal and state environmental regulations, agreements, and permits associated with the SSP and with the Waste Operations Branch (WOB) for planning, reporting, and funding.

ED is composed of two branches, the Environmental Compliance Branch (ECB) and Environmental Programs Branch (EPB).

The ECB supports SRS operations and projects by the review, approval, and submission of documents related to environmental regulatory compliance (except NEPA) such as permit applications, monitoring reports, and project plans for environmental concerns. 


\section{FACILITIES, AND MISSIONS}

This branch directs the development of engineering and scientific data related to regulatory permit requirements. The ECB conducts its work through implementation of the following seven general program areas:

- Water Supply Program

- Waste Management/Environmental Restoration Program

- Radiological Environmental Program

- Wastewater Management Program

- Air Program

- Environmental Emergency Response Program

- Audits and Appraisal Program

The EPB manages environmental studies and impact mitigation activities to support proposed and ongoing SRS projects. This work covers the following four general areas:

- NEPA Implementation

- Environmental Technology Development

- Natural Resource Management

- Geoscience Management

- The Director of the Project Management Division (PMD), reporting to the AMEP, maintains an overview of the total WSRC design and construction effort at SRS and has primary responsibility for interim waste management line item project management. PMD responsibilities include review of projects to ensure that all environmental requirements are fulfilled and appropriate permits are obtained. The PMD Project Management Manual directs staff to ensure that environmental considerations are part of project plans.

- The Office of Chief Counsel (OCC) provides legal advice to the Manager, DOE-SR, and in conjunction with ED, interprets the requirements of environmental laws and regulations as they apply to SRS.

- The Director of the Personnel and Management Evaluation Division (P\&ME), reporting to the Assistant Manager for Administration (AMA), is responsible for maintaining the Recommendations and Findings Tracking System (RAFTS). This computerized database contains recommendations and findings from past inspections, appraisals audits, and other compliance evaluations performed by DOE-SR, DOE-HQ, the General Accounting Office (GAO), and regulatory agencies such as the EPA and SCDHEC. RAFTS is a newly operational, sitewide system that contains evaluations of all SRS organizations. Findings or recommendations contained in the database are presently being verified to ensure that no findings are mistakenly closed. Two areas that are receiving expedited verification of previously close findings are environmental and reactor safety issues. Once all environmental entries are verified, corrective actions on open findings can be implemented in an efficient manner. 


\subsection{DESCRIPTION OF ORGANIZATIONS, FACILITIES, AND MISSIONS}

\subsubsection{Contractor Organizations}

The SRS contractors include: Westinghouse Savannah River Company (WSRC), the operating and engineering contractor (Figure 2.3); the Savannah River Ecology Laboratory (SREL), operated by University of Georgia, which handles both basic and applied research designed to show how ecological entities (e.g., populations, terrestrial or aquatic systems, groundwater, etc.) function under both SRS induced or relaxed stresses and natural conditions; Wackenhut Services Incorporated (WSI), which handles site security; U. S. Forest Service (USFS), which handles land management; and Bechtel Savannah River Company, which handles onsite construction activities (design and constructic.. management). Each contractor is responsible for the safe, environmentally sound maintenance and operation of its designated facilities, specific facility upgrades, operational support, waste management, and monitoring of operations and effluents for environmental compliance. Facility or building managers are responsible for operating their facilities in a safe, environmentally sound manner.

Most waste operations activities, environmental corrective and remedial actions, and decontamination and decommissioning (D\&D) of facilities, conducted at the SRS are performed by or under contract to the WSRC, the operations and engineering contractor. WSRC has been assigned responsibility for management of the Waste Management Program, implementation of the Environmental Restoration Program, and management of the site. The WSRC ensures environmental design requirements are met and provides project support. The WSRC also performs environmental research and development, provides an independent sitewide environmental surveillance program, remediates assigned facilities, and applies waste management technology to support operations and environmental restoration. The WSRC is responsible for waste management and environmental compliance at its assigned facilities.

Within the WSRC, the vice-president for the Nuclear Materials Processing Division (NMPD) is responsible for Waste Management, Environmental Restoration, and DWPF departmental activities. Other departments that conduct some waste management activities are the Reactor Materials Department, Separations Department, Tritium Department, the Power Operations Department, and the SRL.

\subsection{Geographic Size}

The SRS is located in south central South Carolina and occupies an almost circular area of approximately 325 square miles (see Figure 2.4). The major geophysical feature is the Savannah River, which forms the southwestern boundary of the site and is also the South Carolina-Georgia border. The SRS occupies parts of three South Carolina counties-Aiken, Barnwell, and Allendale--and is closest to the major population centers of Augusta, Georgia and Aiken, South Carolina. The site is a controlled area with limited public access. The production facilities occupy less than eight percent of the SRS area. The remainder of the site is forested (approximately 80 percent) or is wetlands (Approximately 20 percent). 


\subsection{DESCRIPTION OF ORGANIZATIONS, FACILITIES, AND MISSIONS}

\subsection{Locations and Descriptions of Installations}

The SRS comprises 18 production, service, and research and development areas scattered across the site. Figure 2.5 shows the locations of these areas. Each area is identified by a numerical and letter designation. Table 2.1 summarizes the letter designations.

The primary facilities are the production facilities. The fuel and target components are manufactured in the 300-M A rea for shipments to the site reactors. The targets and fuel are placed in heavy-water-modeiated production reactors for irradiation. Originally, the site operated five reactors. Currently, two of the reactors, located in the $160-\mathrm{K}$ and $\mathrm{L}$ Areas, are being prepared for operation. Two other reactors, located in the 100-P and C Areas, are in cold standby. The fifth reactor, located in $\mathrm{R}$ Area, is in : shutdown status. The SRS reactors operate at relatively low temperatures and pressures, and they do not produce electricity. The reactors are cooled by a heavy-water moderator, which is then circulated through heat exchangers in a closed loop. Inside the heat exchangers, water withdrawn from the Savannah River and onsite cooling reservoirs is used to remove heat from the heavy water without contacting it. The heavy water is then recirculated through the reactor vessel, and river water is released through an outfall to onsite streams or cooling ponds before returning to the river. The irradiated fuel is transported by shielded railroad cars to either the 200-F or $-\mathrm{H}$ Area Canyons for the recovery of nuclear materials. The $200-\mathrm{F}$ and - $\mathrm{H}$ separations processes dissolve some of the irradiated components in acid and extract and separate the desired nuclear materials. Other products are extracted from irradiated components in separate processes in $\mathrm{H}$ Area. The liquid radioactive waste generated by the separation facilities is neutralized and stored in underground tanks until it can be processed into a glass waste form in the DWPF, currently under construction in the 200-S and $-\mathrm{Z}$ Areas. The glass waste form will be stored onsite until a federal geological repository is available. The nuclear material products are shipped to other DOE facilities for additional processing. The reactor, separations, and waste storage areas are at least four miles from the nearest site boundary. In addition to the underground radioactive waste storage tanks, the SRS has a centrally located 196-acre site between $F$ and $H$ Areas for the disposal of solid low-level radioactive waste and the storage of transuranic (TRU) radioactive waste and mixed waste. The site also has storage buildings for nonradioactive hazardous wastes and mixed waste located in the Central Shops and U Areas along with a central sanitary landfill.

The site also contains many production support, research and development, and waste management facilities. There are three operational coal-fired powerhouses located in $A, D$, and $\mathrm{H}$ Areas to generate electricity and steam. The largest powerhouse, which is located in the 400-D Area, produces electricity and exports process steam to C, F, H, and S Areas through a seven-mile-long steamline. The heavy-water rework facility used to purify reactor moderator is also located in D Area. A semi-works facility used to study chemical and waste processing problems and to test production-scale equipment is located in the 600-T Area. The 700-A Area includes the administrative facilities for DOE and WSRC, the SKL, and the SREL.

The site employs more than 27,000 people. The majority are employed by the WSRC and its subcontractors. The remainder are employed by the DOE-SR, WSI, SREL, and the United States Forest Service (USFS). 


\subsection{Compliance Status and Plans}

A top priority at the SRS is to ensure that onsite processes do not adversely impact the environment. Part of the task involves bringing the site into compliance with all applicable federal and South Carolina environmental regulations and U.S. Department of Energy (DOE) Orders.

\subsubsection{Federal Statutes}

The following summarizes the federal statutes:

\section{Atomic Energy Act (AEA)}

Pursuant to the AEA, DOE is responsible for developing and maintaining a capability to produce nuclear materials required for the defense of the United States. DOE is also authorized to provide certain nondefense nuclear materials, including plutonium-238, for power generators used in civilian space missions. The act also sets forth basic policies and guidance on worker protection and emission standards, including the principle of "As Low As Reasonably Achievable" (ALARA). ALARA describes an approach to radiation exposure control or management whereby the exposures and resulting doses are maintained as far below the limits specified for the appropriate circumstances as social, economic, technical, and practical considerations permit. In support of the AEA, liners will be placed under the emergency retention basin at the $\mathrm{K}$ Reactor to manage radioactive waste. As $\mathrm{L}$ and P Reactors will be placed in standby status, only the work on the K-Reactor liner is proceeding at this time.

\section{Resource Conservation and Recovery Act (RCRA)}

RCRA regulates the management of hazardous waste, nonhazardous waste, underground storage tanks containing petroleum products and hazardous substances, and medical waste. Subtitle C of RCRA mandates that hazardous wastes be treated, stored, and disposed of in a manner that will minimize the threat to human health and the environment. To carry out this mandate, RCRA requires that owners and operators of hazardous waste management facilities obtain operating or post-closure care permits for certain waste management activities.

\section{Land Disposal Restrictions}

In 1984, amendments were made to RCRA which placed restrictions on the storage and land disposal of hazardous wastes. These restrictions are referred to as Land Disposal Restrictions (LDRs) and include the solvent/dioxin and California lists of land disposal regulations. The LDRs applicable to mixed (radioactive and hazardous) wastes require regulatory agreements to address compliance because no treatment currently exists.

\section{Facility Investigation Program}

The Hazardous Waste Permit (SCI-89-0008989) issued to SRS in September 1987, requires the site to institute a program for investigating Solid Waste Management Units (SWMUs). The RCRA Facility Investigation (RFI) Program investigates and remediates, 
if necessary, releases of hazardous waste/constituents from SWMUs at the site. SRS submitted to SCDHEC and EPA Region IV an RFI Program Plan which specified the generic methods and procedures to be used for each unit-specific investigation. Twentytwo work plans, based on the requirement of the RFI Program Plan, were submitted on schedule to the regulators for approval in 1990. The RFI Program Plan under RCRA was expanded to address CERCLA hazardous substances and was renamed the RFI/Remedial Investigation (RFI/RI) Program Plan. The integration of RCRA and CERCLA regulatory requirements under the Federal Facility Agreement (FFA) will provide a more cost-effective and focused investigation and remediation process (see State Regulations: South Carolina Hazardous Waste Management Regulations).

\section{Underground Storage Tanks}

Underground storage tanks at SRS store petroleum products such as gasoline, diesel fuel, and hazardous substances (as defined by CERCLA). All of these tanks are regulated under Subtitle I of RCRA. DOE-SR Field Office requested that WSRC begin a program to abandon or remove all regulated single-wall storage tanks at SRS by 1998. To meet this request, WSRC removed 15 tanks, abandoned five tanks in place, and installed four new tanks during 1990. An additional 21 tanks were tightness tested as required by SCDHEC regulation. In areas where underground tanks are still needed, WSRC will replace the tanks with double-walled tanks having leak detection systems. To complete this project, removal or abandonment is required for 42 additional tanks (see State Regulations: South Carolina Underground Storage Tank Control Regulations).

\section{Hazardous Waste Facilities Location Standards}

RCRA hazardous waste facility location standards regulations became effective in South Carolina in 1991. Under this new regulation, existing and expanding hazardous waste management facilities must submit a compliance demonstration with 180 days of the effective date of the regulation. During 1990, SRS cegan gathering information and data for 14 facilities at SRS. All demonstrations are expected to be available from March 1991 through July 1991 (see State Regulations: South Carolina Hazardous Waste Management Regulations).

\section{Hazardous Waste Management Units}

SRS has closed, or is in the process of closing, fourteen hazardous waste management units: the M-Area Settling Basin, the Mixed Waste Management Facility, three seepage basins in F-Area, four seepage basins in H-Area, acid/caustic basins in F, H, K, and PAreas, and the Metallurgical Laboratory seepage basin. The M-Area, F-Area seepage basins and Mixed Waste Management Facility closures have been certified by the SCDHEC. The H-Area seepage basins are 90 percent complete (as of May 1991). The Acid/Caustic basins and the Metallurgical Laboratory seepage basin closure plans are currently under SCDHEC review.

In 1990, SRS closed 15 nonhazardous/nonradioactive solid waste management units under South Carolina Hazardous Waste Management (SCHWM) regulations (R 51-61). Most of these units were rubble piles left from past construction activities or from Old Ellenton, one of three farming communities relocated before construction of SRS. 

FACILITIES, AND MISSIONS

The SCHWM regulations specify requirements for the accumulation of hazardous wastes without a permit or witholit complying with interim status standards. In a few instances, SRS exceeded the 90-day storage requirements during 1989 and 1990. A settlement agreement with the State of South Carolina was negotiated with SCDHEC to address these violations. (See Consent Orders and Settlement Agreements).

\section{TNX Solvent Plume}

One of several new monitoring wells installed close to the Savannah River at the TNX Facility has confirmed the existence of trichloroethylene. Concentrations up to 400 parts per billion have been detected about 800 feet from the Savannah River. Samples taken at the riverbank and mid-river both upstream and downstream showed no detectable levels. Current plans are to perform water quality analysis from the Savannah River and to continue groundwater sampling and analysis. Additional wells are being installed to assist in the analysis. The plume presents no risk to human health or to the environment.

\section{Clean Air Act (CAA)}

CAA establishes air quality and emission limits throughout the United States. SRS has 14 air quality perrnits covering 141 point sources for air emissions.

\section{National Emissions Standards of Hazardous Air Pollutants (NESHAP)}

The National Emissions Standards of Hazardous Air Pollutants (NESHAP) is a section of the CAA which sets air quality standards for air emissions of hazardous constituents such as radionuclides, benzene, and asbestos.

For radioactive emission sources which have a potential to cause greater than 0.1 mrem/year dose to an offsite individual, NESHAP regulations require specific EPAapproved instrumentation, sampling methodology, calculations, point-source inventory, and modeling which SRS does not have in place. Representatives from EPA Region IV (EPA-IV) inspected a cross-section of SRS moritoring systems in November 1990, and the content of a mutually-agreed-upon supporting information package was determined. On April 1, 1990, this information and a request for approval of overall SRS monitoring methodology for demonstrating compliance was submitted to the EPA-IV. The request was supported by SRS data that provided assurances that the dose level to an offsite individual resulting from SRS operations would be essentially the same as would be obtained using specific 40 CFR 61 subpart $\mathrm{H}$ monitoring methodology. The initial EPA-IV response and subsequent meeting with them indicated that except for the monitoring methodology used at the F- and H-Separations stacks, SRS methodology would likely be acceptable. However, in a June 17, 1991 letter, the EPA notified SRS that they were unable to approve overall SRS monitoring methodology as requested. Consequently, SRS will be required to evaluate which facilities and radionuclides require continuous 
monitoring according to subpart $\mathrm{H}$ and develop a plan for upgrading systems that do not meet requirements. This is being accomplished pursuant to an interim Federal Facilities Compliance Agreement (FFCA) while a final FFCA is being negotiated. SRS is actively pursuing the information required for the FFCA.

\section{Benzene Program}

Benzene is a hazardous constituent that will be produced in the ITP and DWPF processes when operations begin. Plans are to abate benzene emissions with equipment such as catalytic converters to keep emission concentrations with the EPA limit of $10 \mathrm{mg} / \mathrm{L}$ (see State Regulations: South Carolina Air Pollution Control Regulations and South Carolina Ambient Air Quality Standards).

\section{Asbestos Removal Program}

Early construction projects at SRS used a significant amount of asbestos in fireproof wallboard (transite), gasket materials, ceiling tile, insulation, floor tiles, roofing felt, and electric wiring. Consequently, the site has maintained an active asbestos removal program for the past six years, with only trained and licensed personnel removing asbestos. The NESHAP standard does not set a numerical threshold for asbestos fiber emissions; instead, it requires persons conducting asbestos-related activities such as demolition and renovation to notify SCDHEC of removal activities, to follow approved procedures, and to adopt specific work practices to prevent releases of asbestos to the air. Asbestos is removed during maintenance and renovations of equipment and buildings. Health Protection Department determines if the asbestos is radioactive. If it is not radioactive, it is properly containerized (in accordance with federal regulations) and transported to a sanitary landfill onsite. If the asbestos is found to have any radioactivity, it is properly containerized (in accordance with federal regulations) and buried in the low-level radioactive burial ground onsite. In 1990, SRS removed 38,779 linear feet and 127,414 square feet of asbestos. This is roughly equivalent to 7.3 miles of linear asbestos used in materials like pipe insulation and asbestos building materials equivalent to 2.83 football fields. SRS is continuing a program to identify friable asbestos. This is a form of asbestos which can be crumbled or pulverized with hand pressure when dry, releasing fibers into the air. (see State Regulations: South Carolina Standards of Performance for Asbestos Removal Operations).

\section{Clean Water Act (CWA)}

CWA of 1972 created the National Pollutant Discharge Elimination System (NPDES) program. This program regulated by SCDHEC, under the authority of the E.PA, limits nonradiological effluent discharges at each SRS outfall to ensure onsite streams meet South Carolina water quality standards.

Through October 1990, an SRS NPDES permit (SC0000175) regulated 76 active NPDES outfalls at the site. In November, another NPDES permit was issued for five additional outfalls. This new NPDES permit (SCO044908) will allow future wastewater discharges from the K-Reactor cooling tower, A-Area powerhouse, SRL complex air stripper, TNXArea Sanitary Wastewater Treatment Plant, and well flushing operations and tank overflow 

FACILITIES, AND MISSIONS

from A-Area wells. Seventy-six of th: 81 permitted outfalls were sampled during 1990 (the five new outfalls were not operating,

Since 1986, the compliance rate for SRS NPDES regulated discharges has remained above 99 percent. In 1990 , only 16 of 6,810 analyses, which occurred at 12 different outfalls, exceeded NPDES permit limits, for a compliance ratio of 99.8 percent. Thesu findings, including probable cause and corrective actions, were forwarded to SCDHEC.

A groundwater treatment facility near the Savannah River Laboratory (northern part of A Area) was installed on April 1, 1991. The project was completed several months ahead of schedule. WSRC conducted an aquifer test in the southern sector of the A/M Area. This is the first aquifer test performed at SRS, which formally incorporated the requirements of NQA-1. (NQA is Nuclear Quality Assurance.) This is a test to determine the amount, if any, of radionuclides in the water. The water produced during the test was used to evaluate spray irrigation devices for treating volatile organic chemicals contaminated by purger water from monitoring wells.

\section{Federal Water Pollution Control Act (Water Quality Act of 1987)}

The Federal Water Pollution Control Act (Water Quality Act of 1987) reauthorizes and strengthens the Clean Water Act. The Water Pollution Control Act requires that discharges to the navigable water meet applicable thermal limitations or receive a waiver based on the demonstrated presence of a balanced biological community (see State Regulations: South Carolina Water Classification Standards, Classified Waters, and South Carolina Water Classification Standards).

\section{Safe Drinking Water Act (SDWA)}

The SDWA requires the DOE to obtain applicable permits and satisfactorily complete required sample analyses and site inspections of public/industrial water supplies and sources of drinking water. The EPA has authorized South Carolina to regulate both public/industrial water supplies and sources of drinking water. This act also imposes requirements on the installation and maintenance of drinking water wells (see State Regulations: South Carolina Well Standards and Regulations, and South Carolina Drinking Water Regulations).

\section{Drinking Water}

After the site determined a potential for drinking water contamination in D Area, employees in that area were provided drinking water from another potable source (bottled water). D Area was the only area on SRS that used treated water from the Savannah River for drinking purposes. The potential for drinking water contamination resulted from cleaning drinking water filters with water that was not drinking water quality. Employees in D Area will continue using drinking water from another approved source until completion of a project which will use deep wells for drinking water (see Safe Drinking Water Act, and State Regulations: South Carolina Drinking Water Regulations, and South Carolina Well Standards and Regulations). 


\section{Comprehensive Environmental Response, Compensation, and Liability Act (CERCLA)}

CERCLA, Public Law $96-510$ as amended by the Superfund Amendments and Reauthorization Act (SARA, Public Law 99-499) in 1986, provides liability, compensation, cleanup, and emergency response for hazardous substances released to the environment. In December 1989, SRS was officially included on the national Priority List (NPL) or Superfund list. In accordance with Section 120 of CERCLA, DOE is negotiating a Federal Facility Agreement (FFA) with the EPA - Region IV and SCDHEC to coordinate CERCL.A and RCRA activities at SRS into one comprehensive strategy. It is expected that the agreement will be signed in 1991.

CERCLA also requires public participation in the selection of remediation alternatives. Included in this process is the establishment of an Administrative Record that documents the remediation alternatives and allows public review of these alternatives. The SRS Public Involvement Plan (PIP) process addresses the requirements of CERCLA, RCRA, and National Environmental Policy Act (NEPA).

CERCLA requires that the National Response Center (operated by the U. S. Coast Guard) be notified in the event that a non-permitted release of a reportable quantity of hazardous substance or radionuclide occurs. SRS has sitewide procedures in place to ensure that all applicable releases are reported. This system, known as Site Item Responsibility and Issue Management (SIRIM), is used for reporting events or concerns related to safety, health, environment, quality assurance, security or operations to DOE-HQ and appropriate offsite regulatory agencies. Once reported, occurrences are categorized, evaluated, investigated, and reviewed by WSRC and DOE-SR to ensure that notifications are made and that corrective action is taken.

In the case of such a release, the National Response Center alerts the appropriate federal emergency personnel to decide if government response is appropriate and to assess the response measures taken by others. If the release of a reportable quantity could result in exposure of persons outside the boundaries of the facility (SRS boundary), the Emergency Planning and Community Right-to-Know Act (EPCRA) requires that the Local Emergency Planning Committee and the State Emergency Response Commission of an area likely to be affected be notified.

\section{Reportable Releases}

There were no CERCLA reportable releases at any SRS in 1990. There were two CERCLA-reportable releases at SRS from January 1, to April 1, 1991. The first, a threegallon heavy water release, occurred on January 29 in K Area. The sight glass on the distillation column "A" reboiler ruptured, spilling 55 gallons of heavy water inside the diked area. The sight glass developed a leak as a result of freezing conditions. As a result, approximately three gallons of heavy water were sprayed outside the diked area to the asphalt. The second release occurred in K Area on February 18, when approximately 160 gallons of water/heavy water was spilled to the pad, ground, and air. 


\section{Savannah River Swamp}

The Savannah River Swamp has been contaminated, which could result in a potential offsite dose to the general public. The contamination is a result of past effluent discharges contaminated with cesium-137 from P-Reactor to Steel Creek. The area where contamination of swamp sediment has occurred is well characterized and routinely monitored. This area is uninhabited and inaccessible except for occasional workers and occasional trespassing hunters and fishermen. Monitoring of Steel Creek, the swamp, and the river has confirmed that there is no significant migration of the cesium-137. Routine annual surveys of the area will continue to be conducted and published in the annual Site Environmental Report. Appropriate actions will be initiated if there is any significant changes in the property usage and/or migration patterns of cesium-137.

\section{Toxic Substances Control Act (TSCA)}

TSCA ensures that the manufacture and sale of chemical substances and mixtures do not present an unreasonable risk of injury to health or to the environment. The principle applicability of the TSCA to SRS operations is in the management and disposal of PCBs.

\section{Polychlorinated biphenyls (PCBs)}

PCBs have been used, in the past, in various equipment on the site. During some nonroutine SRS operations, some PCBs have been radioactively contaminated. TSCA regulations call for annual disposal of PCB waste; however, no capacity exists for disposal of radioactive PCBs, either on or offsite. Therefore, these wastes will continue to be stored onsite until a form of treatment is developed. DOE, EPA Region IV, and SCDHEC are aware of this issue. SRS is actively pursuing resolution of this issue by surveying DOE facilities for availability of treatment and/or treatment capacity. This issue is expected to be resolved by a settlement agreement in late 1991 .

\section{SARA Title III Reporting Requirements}

EPCRA, 1986, enacted as a provision to SARA, requires industries to report the hazardous substances used at their facilities to state and local emergency planning units. This requirement includes reporting inventories (amounts onsite and typical usage) of these substances. Industries must also report all planned and unplanned releases to the environment.

Under SARA, SRS must file an annual Tier II Inventory Report by March 1 to the South Carolina Emergency Response Commission and to the local emergency planning committees in Aiken, Barnwell, and Allendale counties. SRS also supplies the report to Georgia's Emergency Response Commission as a courtesy. This inventory report lists all hazardous materials stored onsite in excess of specified quantities during the previous calendar year.

As required by SCDHEC, SRS uses a Tier II report as opposed to a Tier I report. The Tier II report documents chemical-specific data and gives more information than the Tier I 
report. For example, on the Tier I report, acids are listed only as "acids," while the Tier II report identifies specific acids and lists them separately.

SRS must also file an annual Toxic Chemical Release Inventory Report to the EPA and SCDHEC by July 1 for regulated chemicals if the combined usage of a chemical exceeded $10,000 \mathrm{lb}$ during the previous calendar year. On June 28, 1990, SRS submitted separate reports for each of 13 chemicals.

\section{National Environmental Policy Act (NEPA)}

NEPA provides a means to evaluate the potential environmental impacts of proposed federal activities and to examine alternatives to those actions. In 1982, a formal NEPA compliance program was established at SRS. In 1990, WSRC conducted approximately 370 reviews for proposed federal actions at the SRS and formally documented these reviews through a Categorical Exclusion, Memorandum-to-File (no longer used in DOE), Environmental Analysis or Environmental Assessment (EA). WSRC also provided technical support to DOE-SR for the preparation of Environmental Impact Statements (EIS).

NEPA activities conducted during 1990 included the following:

- A draft EA on the Refurbishment and Operation of Pu 238 Non-Reactor Facilities was approved by DOE-SR/Environmental Division in September 1990. This process will produce heat sources for the U. S. space program.

- An EA of the DWPF modifications was approved by DOE.

- A final draft EA on the Operation and Modification of the New Special Recovery Facility in F Area was submitted to DOE-SR for review. The facility will recover plutonium from plutonium scrap and metal.

- A draft EA on the Plant-wide Fire Protection Project was prepared. This project will upgrade fire protection for the site.

- Preparation of the EIS for the New Production Reactor continued.

- The Final EIS for the Continued Operations of P, K, and L Reactors was approved, and a Record of Decision was issued by the Secretary of Energy.

- An analysis of the changes/modification for the K-Area Cooling Tower Project, assessed in the Alternative Cooling Water EIS, was submitted to DOE for review.

- A revised EA for the Consolidated Incinerator Facility was prepared.

\section{Endangered Species Act}

The Endangered Species act requires every federal agency to ensure that its action and those of its contractors are not likely to jeopardize the continued existence of any endangered or threatened species or result in the destruction or adverse modification of a 


\subsection{DESCRIPTION OF ORGANIZATIONS, FACILITIES, AND MISSIONS}

critical habitat, unless an exemption, as defined in Sections $1536(\mathrm{a})(2)$ and $(\mathrm{h})$, has been granted by the Endangered Species Committee. At SRS, this is one of the criteria examined prior to the siting/construction of any new site facility.

\section{National Historic Preservation Act}

The National Historic Preservation Act requires a survey listing mitigation actions for historical artifacts. As with the Endangered Species Act, this is also one of the criteria examined prior to the siting/construction of any new site facility.

\section{Federal Insecticide, Fungicide, and Rodenticide Act (FIFRA)}

The Federal Environmental Control Act of 1972 regulates the use of classified pesticides through a certification program. WSRC's pesticide procedure controls the pesticides utilized onsite and certified applicators oversee the application of classified pesticides.

\subsubsection{State Regulations}

Many of the State of South Carolina laws mirror the federal laws. As with the federal laws, SRS must comply with all applicable state laws. Summaries follow:

\section{South Carolina Pollution Control Act}

The South Carolina Pollution Control Act requires DOE to comply with applicable South Carolina environmental regulations.

\section{South Carolina Water Use Reporting and Coordination Act}

The South Carolina Water Use Reporting and Coordination Act authorizes the South Carolina Water Resources Commission (WRC) to require reporting information concerning substantial use, withdrawal, or diversion of surface, underground or other waters of the state. Required information includes identification of the locations of wells or facilities where water is used, withdrawn, or diverted; the source and location of the water; and the total amount of water used, withdrawn, or diverted.

\section{South Carolina Nongame and Endangered Species Act}

The South Carolina Nongame and Endangered Species Act protects state nongame species in need of management and species listed by the State as endangered. Consultation with the South Carolina Wildlife and Marine Resources Commission is required if a listed species is present in an area to be disturbed by construction or ongoing operation of a new facility.

\section{SCDHEC NPDES Permit (SC0000175)}

The SCDHEC NPDES Permit directs SRS to prepare a Best Management Practices Plan to identify and control the discharge of hazardous and toxic substances listed in 40 CFR Part 117 and Tables II and III of Appendix D to 40 CFR Part 22. 


\subsection{DESCRIPTION OF ORGANIZATIONS, FACILITIES, AND MISSIONS}

\section{South Carolina Wastewater Regulations}

The South Carolina Wastewater Regulations require DOE-SR to obtain Wastewater Treatmeni Facility Construction Permits for the construction of any wastewater treatment facilities and sewers. After construction is completed, an operating permit must be obtained.

\section{South Carolina Drinking Water Regulations}

South Carolina Drinking Water Regulations require the DOE to obtain applicable permits and satisfactorily complete required sample analyses and site inspections of public/industrial waste supplies and sources of drinking water. The EPA has authorized South Carolina to regulate both public/industrial water supplies and sources of drinking water.

\section{Solid Waste Regulations}

Solid Waste Regulations specify procedures to be followed for closing or abandoning solid waste disposal sites. Stipulated requirements include post-closure monitoring by at least one monitoling well with readings taken every three months for submittal to the Solid Waste Division, State B Jard of Health. Post-closure monitoring requirements that include the use of a monitoring well implies an assessment of the location of the water table and the downgradient direction.

\section{South Carolina Air Pollution Control Regulations}

South Carolina Air Pollution Control Regulations set standard requirements for construction and operating permits and for renewing permits. These regulations also require permits for open burning and require emergency action plans to deal with releases of hazardous air pollutants.

\section{South Carolina Ambient Air Quality Standards}

South Carolina Ambient Air Quality Standards set standards for visible emissions and requirements for opacity monitoring and source tests. This regulation also sets emissions limitations for certain source types and Prevention of Significant Deterioration (PSD) requirements.

\section{Industrial Solid Waste Disposal Site Regulations}

Industrial Solid Waste Disposal Site Regulations require a permit for operating any industrial solid waste system. If the industrial waste system involves hazardous waste, then a groundwater monitoring system nuust be developed into the site plan. If hazardous waste is present, groundwater monitoring requirements imply an assessment of the water table and downgradient direction.

\section{South Carolina Water Classification Standards}

South Carolina Water Classification Standards require that all SRS navigable waters meet Class B Water Quality Standards. The standards require Class B stream temperatures to be 

FACILITIES, AND MISSIONS

90 degrees Fahrenheit or less or not to cause ambient temperatures to increase by more than 5 degrees Fahrenheit.

\section{Classified Waters}

Classified Waters define the usability of surface and ground waters of the State and for what they are suitable. This regulation stresses the importance of the waters of the State and how they should be maintained.

\section{South Carolina Landfill Regulation}

South Carolina Landfill Regulation requires an owner or operator of a solid waste disposal facility to obtain a permit to operate a sanitary landfill. In addition, observation test wells that provide reliable data on groundwater contamination must be included in the site design. The requirement for monitoring wells implies an assessment of the location of the water table and downgradient direction.

\section{South Carolina Well Standards and Regulations}

South Carolina Well Standards and Regulations are applicable to most newly constructed wells, including water supply wells, monitoring wells, and piezometers. These regulations establish certain minimum standards for well construction, well locations, and well closures. To satisfy this requirement, a water well record form for each well must be submitted to SCDHEC within 30 days after the completion of the well.

\section{South Carolina Hazardous Waste Management Regulations}

South Carolina Hazardous Waste Management Regulations describe the requirements of the hazardous waste management program administered by the State. Hazardous waste management in the hazardous waste storage buildings (except the Mixed Waste Storage Building) are operated under a Part B permit issued in 1987. All other hazardous waste management activities at the SRS are currently being conducted under Interim Status Standards. As such, facilities must comply with the Interim Status Standards and must not engage in hazardous waste activities or processes not specified in the RCRA Part A application. Parts R.61-79.264 and 265 of these regulations establish minimum standards on the management of hazardous waste for owners or operators of permitted hazardous waste treatment, storage, and disposal facilities. The groundwater protection standards required by this regulation will be met once the SRS obtains its complete permit. Groundwater monitoring requirements require extensive knowledge of the hydrogeological regime.

\section{South Carolina Standards of Performance for Asbestos Removal Operations}

South Carolina Standards of Performance for Asbestos Removal Operations set requirements for the removal and handling of asbestos when a facility is either removed or dismantled. 


\section{Underground Injection Control Regulations}

Underground Injection Control Regulations specify under what circumstances materials can be injected into the ground.

\section{South Carolina Water Classification Standards}

South Carolina Water Classification Standards require that all SRS navigable waters meet Class B Water Quality Standards, which include limits on total suspended solids and pH.

\section{Underground Storage Tank Control Regulations}

Underground Storage Tank Control Regulations require that all tanks installed after January 1,1986 prevent releases due to corrosion, have a release detection system, and maintain an inventory recordkeeping system. The regulation also includes requirements for notification, permitting, installation, general operations, corrective actions, and abandonment activities.

\subsubsection{Consent Orders and Agreements}

\section{Settlement Agreement 90-64-SW}

The 90-64-SW Settlement Agreement required SRS to condurt a survey of the entire site to determine locations where hazardous wastes were stored fo: more than 90 days in an area that did not have interim status or stored in any area that was not included in the hazardous waste permit for storage. SRS was given until March 1, 1991 to correct any deficiencies found during the survey. With the exception of one deficiency, SRL lead waste, all deficiencies were corrected by the agreement date. SCDHEC gave SRS an extension until March 15, 1991 for the SRL lead waste. The waste was repackaged and subsequently moved to interim status storage on March 8, 1991. Two other deficiencies not on the original survey were allowed to be included by SCDHEC. The first was a 91 -day storage situation at a reactor staging area. The second was a greater than 90-day storage of several drums of hazardous waste. Both of these deficiencies were corrected before March 1 , 1991.

\section{Fish Kills Agreement}

DOE-SR and SCDHEC have negotiated two settlement agreements regarding minor thermal impacts and fish kills resulting from SRS discharges. Both settlement agreements were signed and sent to SCDHEC. Plans of action for these discharge concerns have since been developed and transmitted to SCDHEC as prescribed by the settlement agreement.

\section{K-Reactor Cooling Tower (Consent Order 84-4-W)}

The National Pollutant Discharge Elimination System (NPDES) permit for the cooling tower discharge was issued by SCDHEC on October 25, 1990. The effective date of the permit was December 1, 1990. Early construction activities that were approved by SCDHEC prior to receipt of the NPDES and construction permits continue. The construction permit for the cooling tower was issued by SCDHEC on November 9, 1990. 

FACILITIES, AND MISSIONS

This permit allows construction of the tower and associated pipelines, controls, etc. The project remains on schedule to meet the Consent Order December 31, 1992 operational date.

\section{Section 316(a) Demonstration}

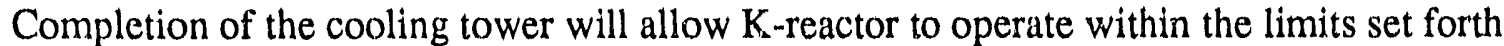
in the South Carolina Water Quality Standards thermal criteria. As part of tower operation (and the Consent Order mentioned above), a CWA Section 316(a) demonstration will be conducted to determine the presence of a balanced biological community in the streams receiving effluent from the tower. A study plan for this demonstration has been prepared by the Savannah River Laboratory and submitted to SCDHEC.

\section{A Federal Facility Agreement (FFA)}

The FFA is currently being negotiated for the site to specify how the RCRA and CERCLA regulatory programs will be integrated at SRS. This Agreement outlines the framework of remediation and schedules for producing work plans and site investigations. Consequently, SRS is developing a comprehensive program to determine the environmental effects of past waste disposal practices and proceeding with remedial actions, as necessary.

\section{Federal Facilities Compliance Agreement (FFCA)}

The FFCA, signed on March 13, 1991, by EPA and DOE-SR to address SRS mixed (radioactive and hazardous) waste compliance with RCRA Land Disposal Restrictions (LDRs). The FFCA allows SRS to continue to operate, generate, and store wastes that are prohibited from land disposal by the solvent/dioxin and the California list of land disposal regulations. 
2.0 DESCRIPTION OF ORGANIZATIONS, FACILITIES, AND MISSIONS

Table 2.1 Letter/Number Designations and Functions of Site Installations

Facility

Nuclear Production Reactors

Solid Waste Complex

Chemical Separation

Defense Waste Processing

Saltstone

Fuel and Target Fabrication

Heavy Water Rework

Powerhouse

General Facilities and Services

TNX Semi-Works Facilities

Administration, Technical, and Shops
Area

$100-\mathrm{C}$ $100-\mathrm{K}$

$100-\mathrm{L}$

100-P

$100-\mathrm{R}$

700-E

200-F

200-H

200-S

$200-\mathrm{Z}$

300-M

400-D

600

$600 \mathrm{~T}$

$700 \mathrm{~A}$
Function

Irradiate fuel and target elements for production of nuclear materials.

Treats/disposes/stores low-level, intermediate-level, mixed, hazardous, and transuranic wastes.

Chemically separate and process the irradiated materials from the reactors. High-level radioastive wastes are also stored and processed in these ireas.

Will process high-level waste into borosilicate glass waste form for storage until final disposal in an asyet undesignated repository by DOE.

Will process saltstone for disposal in early 1900.

Manufactures fuel and target elements for use in the reactors.

Purifies heavy water for use as reactor moderıtor.

Generates steam and electricity.

Includes the Low-Level Waste (LLW) Disposul Facility. Includes all of SRS that is not withir or functionally associated with a fenced area such as designated bridges, roads, parking lots, storage tanks, monitoring stations and towers, transfcrmers, boat ramps, training areas, and repair shops.

Used to study chemical processing problems and test production-scale equipment and processes.

Includes the SRL which performs $R \& D$ related to plant changes, improvements, upgrades, and vaste management.

The administration area for DOE, WSRC, and SRL includes medical facilities, automotive shops, warehouses, fire stations, a powerhouse, coal storage, lumber and steel yards, and gas stations. 
2.0 DESCRIPTION OF ORGANIZATIONS,

Table 2.1 Letter/Number Designations and Functions of Site Installations (Contd)

Facility

Security Services

Components Test Area

Central Shops

U. S. Forest Service
Area

$700 \mathrm{~B}$

$700 \mathrm{U}$

CS

USFS
Function

The administration and service area for security contractor, WSI, and includes training facilities.

Includes a test reactor no longer in service. Includes the hazardous waste storage facility.

Includes a variety of functions, including equipment storage, painting carpentry, automotive repairing, asphalt storage, blacksmithing, construction storage, concrete mixing, photo processing, structural iron working, coal sampling, and fire department training.

I

Includes administrative headquarters, storage, and maintenance sheds. Also contains offices for USC Institute of Archeology and Anthropology. Wildlife and Marine Resources Unit, and AT \& T Southern Bell. 


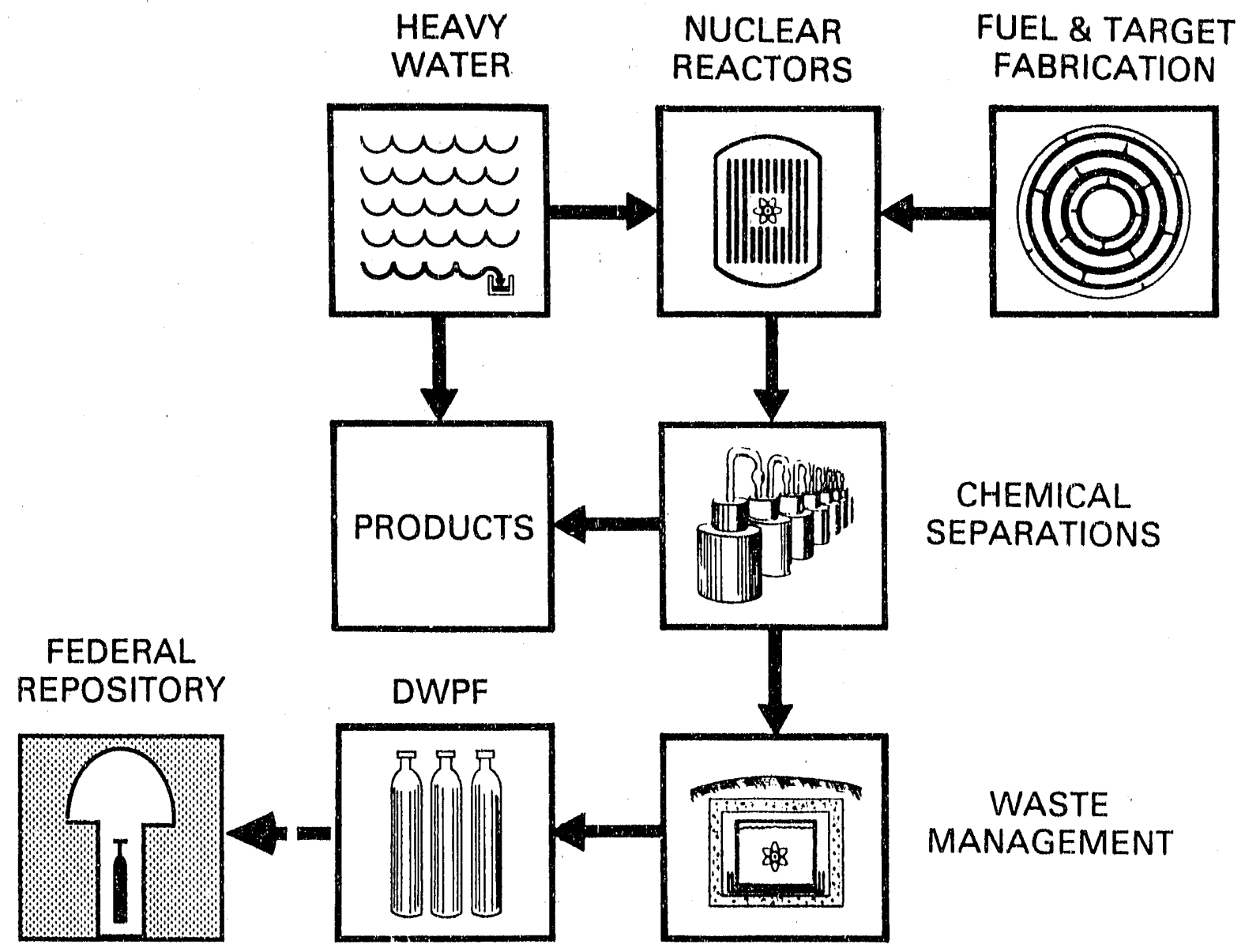

Figure 2.1 Materials Flow Diagram 


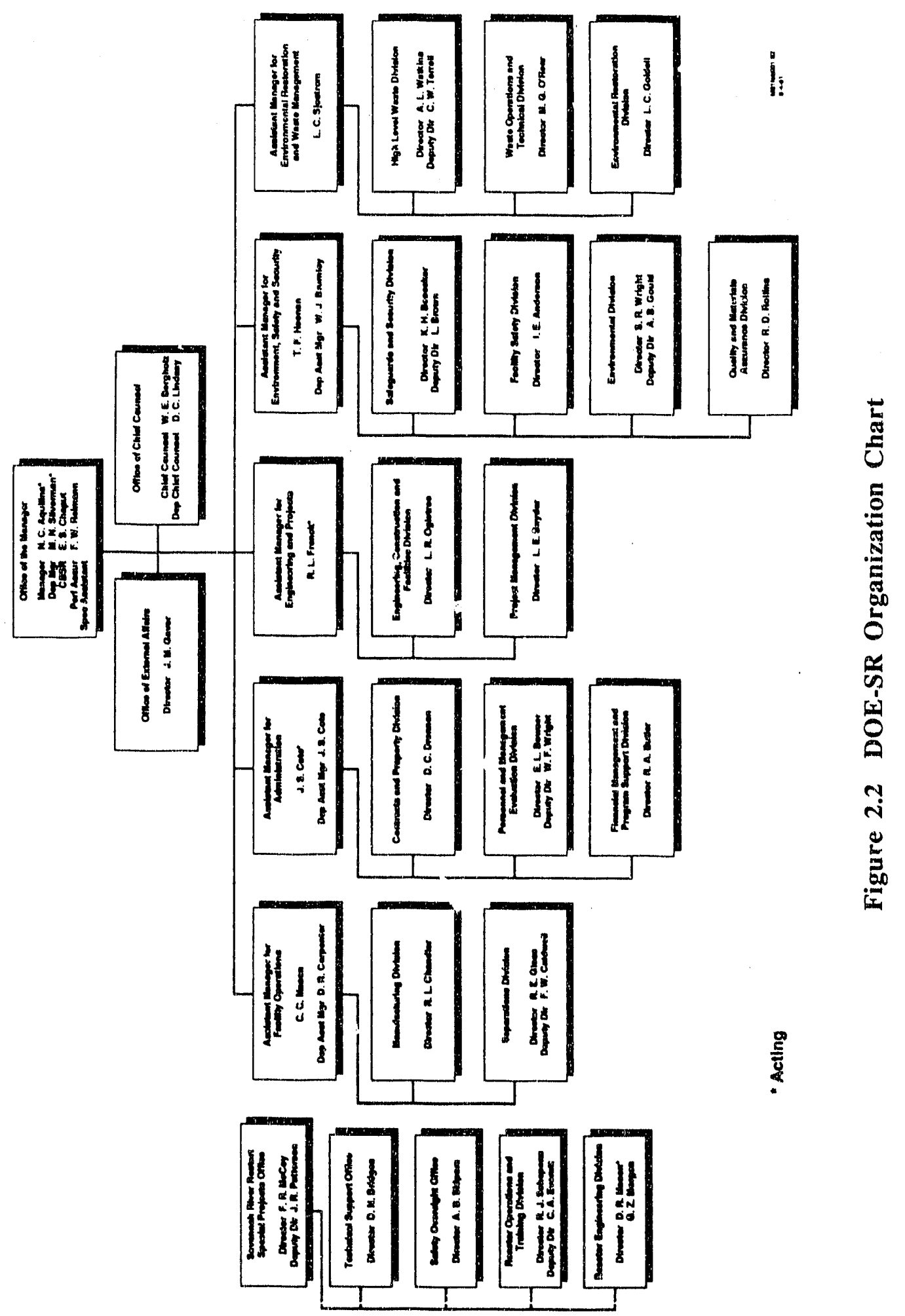




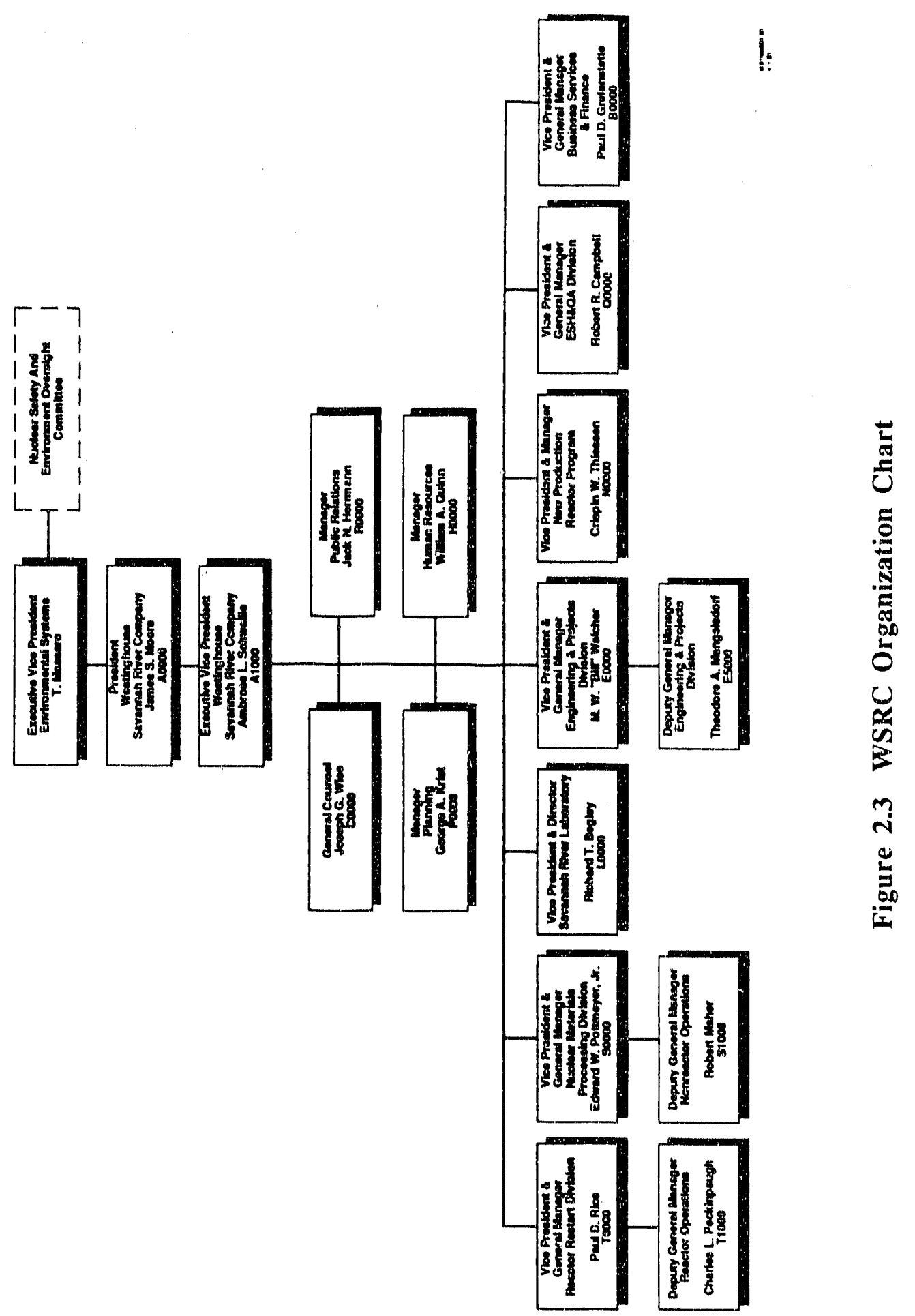




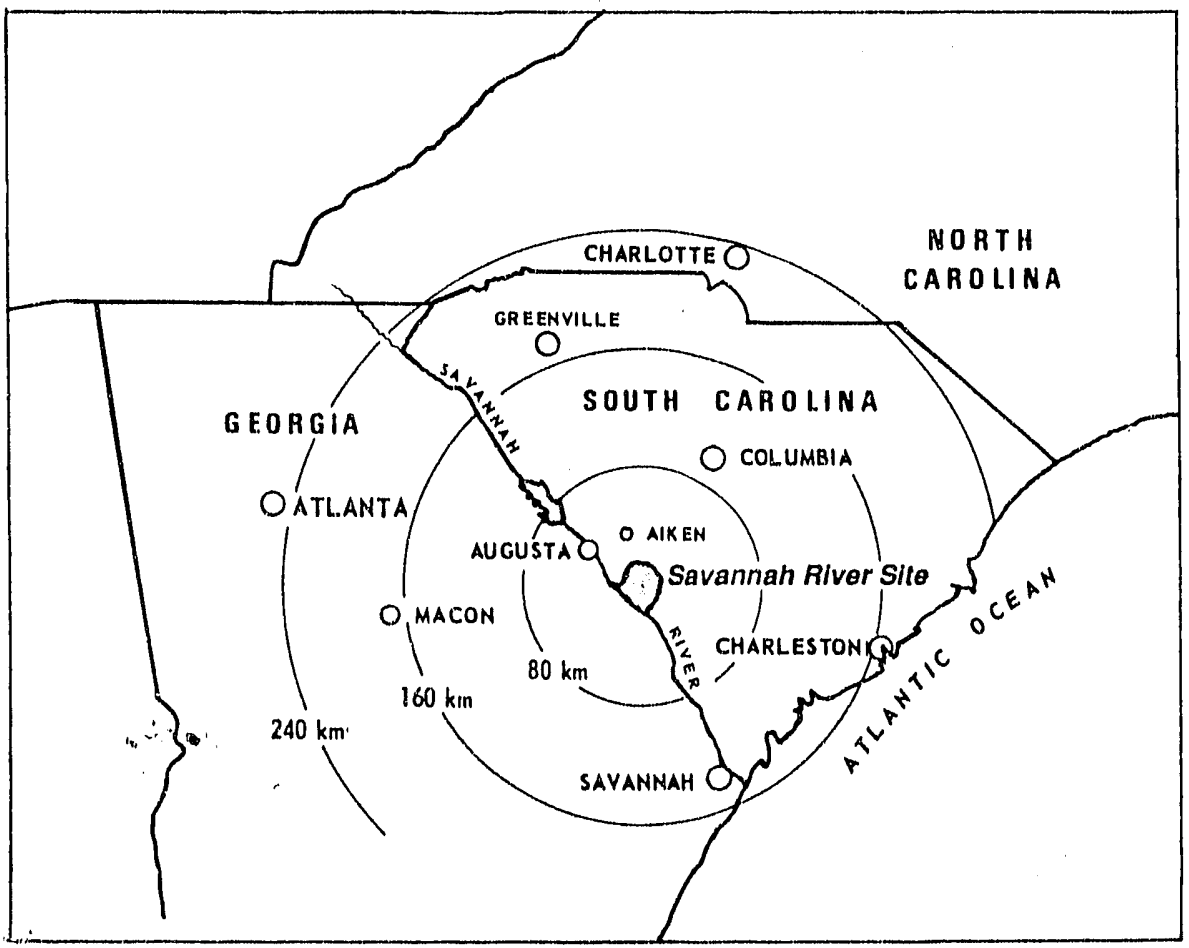

Figure 2.4 Regional Location of SRS 
FACILITIES, AND MISSIONS

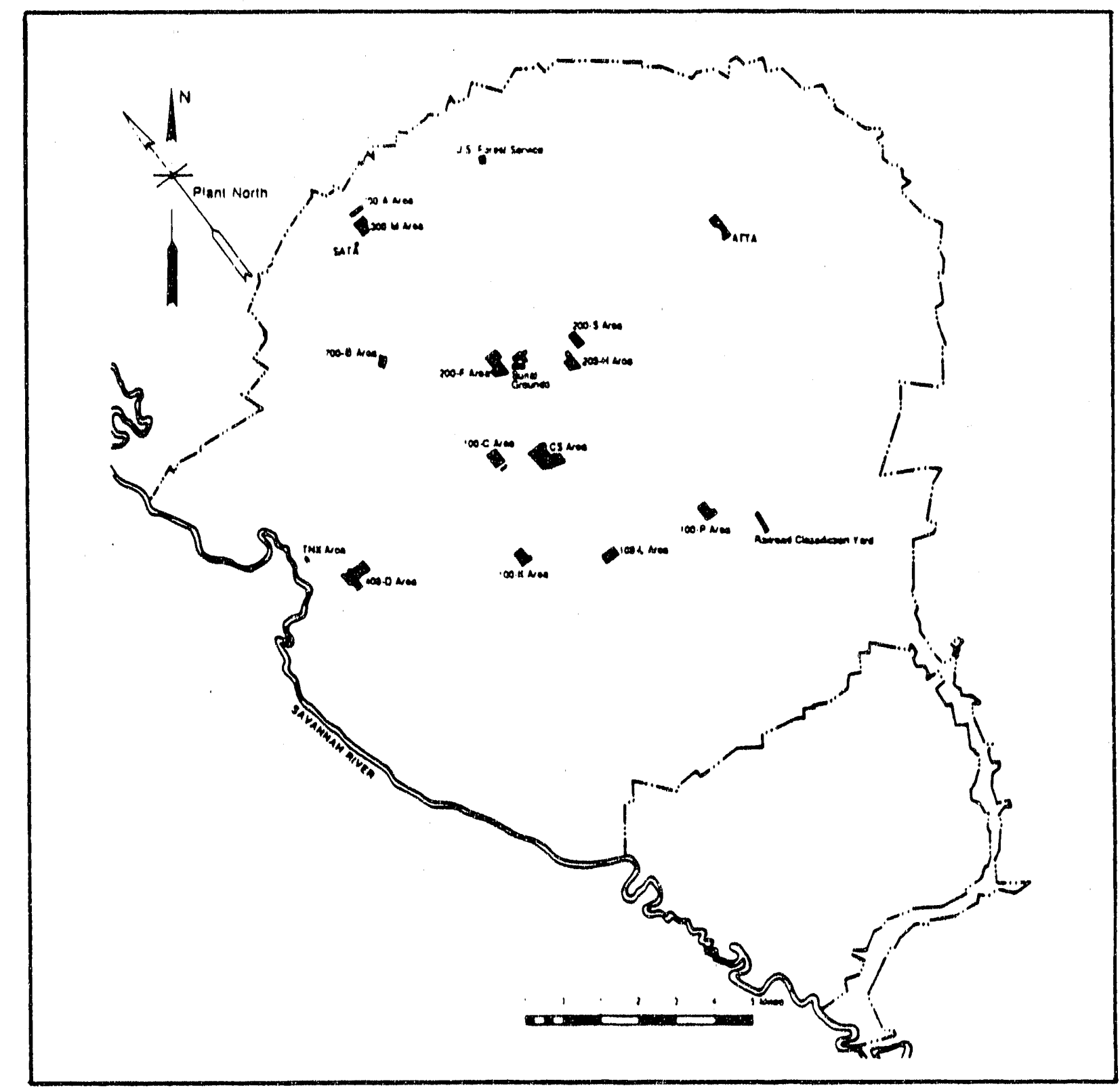

Figure 2.5 Installation Sites in the Savannah River Site 


\section{CONTENTS}

Section 3.0 Primary Site-Specific Objectives by Program 1

3.1 Corrective Activities

3.1.1 Introduction

3.1.2 Description of Activities

3.2 Environmental Restoration

3.2.1 Introduction

3.2.2 Description of Activities

3.3 Waste Management Operations

3.3.1 Introduction

3.3.2 Description of Activities

3.3.2.1 Power

3.3.2.2

3.3.2.3

3.3.2.4

3.3.2.5

Reactor Materials

Reactors

Separations

Tritium Facility

3.3.2.6 Waste Management

3.3.2.6.1 High-Level Waste Management 13

3.3.2.6.2 Low-Level Solid Waste Management 17

$\begin{array}{ll}\text { 3.3.2.6.3 Transuranic Waste Management } & 23\end{array}$

3.3.2.6.4 Hazardous Waste Management 26

$\begin{array}{ll}\text { 3.3.2.6.5 Mixed Waste Management } & 27\end{array}$

$\begin{array}{lll}3.3 .2 .6 .6 & \text { Sanitary Waste Management } & 28\end{array}$

$\begin{array}{lll}3.3 .2 .7 & \text { Defense Waste Processing Facility } & 29\end{array}$

$\begin{array}{lll}3.3 .2 .7 .1 & \text { Vitrification } & 29\end{array}$

$\begin{array}{lll}3.3 .2 .7 .2 & \text { Saltstone } & 29\end{array}$

3.3.2.8 Savannah River Laboratory $\quad 30$

3.3.2.8.1 Low-Level Waste 30

3.3.2.8.2 High-Level Waste 31

3.3.2.8.3 Low-Leval Mixed Waste $\quad 34$

$\begin{array}{lll}3.3 .2 .8 .4 & \text { Sanitary Waste } & 34 \\ 3 & & 34\end{array}$

$\begin{array}{lll}3.3 .2 .8 .5 & \text { Hazardous Waste } & 35\end{array}$

$\begin{array}{lll}3.3 .2 .8 .6 & \text { Transuranic Waste } & 35 \\ 3.32 & \end{array}$

$\begin{array}{lll}3.3 .2 .8 .7 & \text { Other } & 35\end{array}$

$\begin{array}{lll}3.4 & \text { Technology Development } & 37\end{array}$

$\begin{array}{lll}3.4 .1 & 37\end{array}$

3.4.2 Description of Activities 37

3.4.2.1 Waste Retrieval and Waste Processing 37

$\begin{array}{lll}3.4 .2 .2 & \text { Integrated Demonstrations } & 38\end{array}$

3.4.2.3 Administrative Support and Planning $\quad 39$

$\begin{array}{ll}3.4 .2 .4 \text { Education } & 40\end{array}$ 


\section{LIST OF FIGURES}

Page

3.1 Savannah River Site Waste Site Closure Pathway

41

3.2 Conceptual Plan for Pretreatment Process

3.3 Savannah River Site High-Level Radioactive Waste Management Plan

3.4 Savannah River Site F- and H-Area Effluent Treatment Facility

42

43

Waste Management Plan

3.5 Savannah River Site Low-Level and Intermediate-Level

44

Waste Management Plan

3.6 Solid Waste Disposal Facility, E Area

3.7 E-Area Vaults

3.8 Consolidated Incineration Facility

3.9 Transuranic Waste Management Plan

47

3.10

Nonradioactive Nonhazardous Waste

3.11

Hazardous Waste/Mixed Waste Disposal Facility

3.12 Mixed Waste Management Plan

3.13 Savannah River Site Saltstone Disposal Plan 


\subsection{PRIMARY SITE-SPECIFIC OBJECTIVES BY PROGRAM}

\subsection{Corrective Activities}

\subsubsection{Introduction}

Corrective Activities from the Environmental Restoration and Waste Management FiveYear Plan (DOE 1989a) are defined as those activities needed to bring active and standby facilities currently out of compliance with applicable local, state, and federal requirements, and internal DOE requirements, into compliance in an expeditious manner. The current definition of Corrective Activities does not include activities that are necessary for maintaining environmental compliance at the site.

In addition, SRS is now placing greater emphasis on self-assessment activities to identify potential environmental compliance issues at SRS. SRS is conducting a thorough selfassessment of compliance activities at all SRS facilities. The assessment involves facility inspections (walkdowns) and record reviews. It has identified some radioactive materials as potentially subject to RCRA hazardous waste management requirements. SRS has informally discussed with SCDHEC the protocol for involving SCDHEC. SCDHEC supports the concept that SRS is implementing.

For the FYP, Corrective Activities are grouped into three categories: air, water, and solid waste, per guidance from DOE-HQ.

Air Corrective Activities are conducted to reduce or eliminate unacceptable releases of contaminants to the atmosphere via regulated sources such as stacks and exhaust vents (DOE 1989a).

Solid Waste Corrective Activities are conducted to bring solid waste management operations, that have or may have caused contamination of soil and groundwater into compliance. Solid Waste Corrective Activities are needed to comply with local, state, and federal solid waste (including hazardous waste generation, storage, treatment, and disposal) and groundwater protection statutes, codes, ordinances, and other requirements (DOE 1989a).

Water Corrective Activities are conducted to reduce or eliminate unacceptable discharges of contaminants to surface water, such as those regulated under the National Pollution Discharge Elimination System (NPDES) Program (DOE 1989a). The only Corrective Activity that was identified at SRS was a single Water Corrective Activity.

The SRS complies with the CWA and the SCDHEC wastewater regulations except for thermal effluent limitations. During reactor operation, reactor noncontact cooling water has been discharged at greater than 70 degrees centigrade (175 degrees Fahrenheit) to several of the site streams. The site constructed PAR Pond and L Lake to mitigate heated water discharges from $P$ Reactor and L Reactor, respectively. In addition, the DOE entered into a Consent Order with the SCDHEC to mitigate the heated water discharges from K Reactor. 


\subsection{PRIMARY SITE-SPECIFIC OBJECTIVES} BY PROGRAM

Most operations effluents from SRS facilities discharge through point source outfalls. Discharges from the outfalls are regulated by the SCDHEC under the NPDES permit. Some operational discharges (shielding waters and cooling waters) are presently discharging to seepage areas but will be rerouted to permitted outfalls.

\subsubsection{Description of Activities}

As discussed above, only one corrective activity is still underway onsite. This activity concerns the K-Reactor effluent cooling thermal mitigation. A natural draft cooling tower is being constructed in this activity. In contrast to the present once-through cooling systems, the primary portion of the flow will be recirculated to the existing cooling water reservoir for reuse in the reactor building. The remaining portion, the blowdown, will be discharged to an existing effluent stream.

Past operations of the $\mathrm{K}$ Reactor have resulted in the receiving stream's temperature exceeding 90 degrees Fahrenheit. The new cooling tower will reduce the discharge temperature below state requirements. The SRS will be able to operate this reactor because of Consent Agreement 84-4-W that the site has with the state. This agreement allows the reactor to operate while the cooling tower is being built, as long as it meets the milestones in the agreement. The consent order requires the cooling tower construction to be completed and meet the NPDES requirements by December 31, 1992.

\subsection{Environmental Restoration}

\subsubsection{Introduction}

The Westinghouse Environmental Restoration (ER) Department was formed in FY 1991 to consolidate the ER activities at the SRS. ER is responsible for all aspects of assessment and cleanup of sites and facilities that are no longer a part of active operations but are contaminated with various quantities of hazardous, radioactive, or mixed waste materials. ER is also responsible for inactive waste sites which are nonhazardous and nonradioactive. ER performs two sets of activities: Remedial Actions and Decontamination and Decommissioning (D\&D). The Remedial Action tasks encompass 1) site characterization, analysis of cleanup alternatives, and selection of remedy; 2) cleanup and site closure; and 3) site compliance monitoring. D\&D is concerned with the safe caretaking of inactive nuclear facilities, and either their decontamination or their complete dismantling and removal.

\subsubsection{Description of Activities}

\section{Regulatory Requirements}

The basic framework for assessing all waste units and developing closure, post-closure, and remedial action plans is based on the hazardous waste requirements of RCRA, CERCLA as amended, South Carolina Solid Waste Regulations (nonhazardous sites), and South Carolina Hazardous Waste Management Regulations (SCHWMR). Waste units at the SRS are identified in the draft FFA and will be addressed under an integrated RCRA/CERCLA Program. The RCRA Requirements have been the primary regulatory driver at the SRS waste units. 


\section{Federal Requirements}

- Resource Conservation and Recovery Act (RCRA)--The State of South Carolina is authorized by the EPA to administer the RCRA. Permitting under the RCRA is a twopart process. The first part involves the submittal of a Part A Permit application that contains certain basic facility information. The second part involves the submittal of a Part B Permit application that contains detailed information about the individual hazardous Waste Management facilities, including closure and post closure activities. The SRS Part B Permit was applied for in February 1985 and has been revised, as needed, to incorporate additional facilities. A permit was issued in September 1987 to
authorize closure and post closure activities for the site.

- CERCLA/Superfund Amendments and Reauthorization Act (SARA) (Superfund)-CERCLA is administered by EPA. According to Section 102(a) of CERCLA, agencies of the federal government are procedurally and substantively subject to compliance with this law. The SRS was placed on the National Priorities List (NPL) in December 1989. DOE-SR is currently in the process of negotiating an FFA with the state and

\section{DOE Orders}

- DOE Order 5400.4 -. This order establishes instructions for implementing the DOE CERCLA program and defines actions to identify and evaluate inactive hazardous wast : sites at DOE installations and directs the custodian to take remedial action where necessary to improve control of hazardous substance migration from such sites.

- DOE Order 5400.3--This order establishes hazardous waste management procedures for facilities operated under the authority of the Atomic Energy Act and provides instructions for implementing the RCRA, to the extent practicable.

\section{State Requirements}

State requirements include the following:

- R.61-58

- R.61-60

- R.61-61

- R.61-66

- R.61-68

- R.61-69

- R.61-70

- R.61-71

- R.61-79

- R.61-87

- R.61-92
State Primary Drinking Water Regulations

Solid Waste Regulation

Solid Waste Regulation

Industrial Solid Waste Disposal Site Regulation

Water Classification and Standards

Classified Waters

South Carolina Landfill Regulations

Well Standards and Regulations

SC Hazardous Waste Management Regulations (SCHWMR)

Underground Injection Control Regulations

South Carolina Underground Storage Tank Control

Regulations 


\subsection{PRIMARY SITE-SPECIFIC OBJECTIVES}

In addition, other state regulations may apply to the format or other aspects of closure plans. Until the investigations are complete, it is not known exactly which regulations may apply.

\section{Closure/Environmental Restoration Strategy}

Closure options for the waste units are varied and will be determined on a unit-specific basis. Options for remediation include waste stabilization, site capping, waste removal, and grading. No action may be required at some waste sites, in which case, documentation supporting this option will be provided in a report to the regulators. In the preliminary analysis presented in the Environmental Impact Statement (EIS), Waste Management Activities for Groundwater Protection at the Savannah River Plant, DOE/EIS-0120D (DOE $1987 \mathrm{c}$ ), the current plans propose waste removal at the old F-Area seepage basin and at the six R-Area seepage basins. The final closure strategy for all waste sites will, however, depend on the information developed during characterization and assessment.

Groundwater corrective action plans are currently being developed for the TNX and $\mathrm{F} / \mathrm{H}$ Area. Groundwater remedial actions will be performed as needed to comply with groundwater protection requirements resulting from negotiated agreements with regulatory agencies. Corrective actions are complex and depend on many variables, which are often unit specific. Remedial actions include in situ treatment, groundwater extraction with surface treatment, and containment or diversion. An effective design often combines two or more actions. The removal of chlorocarbons from the shallow groundwater in $\mathrm{M}$ Area and vicinity is currently the only groundwater remedial action underway at SRS.

\section{RCRA Part B/RFI Activities}

There are 15 waste sites that are currently subject to RCRA permitting and compliance action by the SCDHEC under the authorized state hazardous waste program. Ten of these waste sites are currently undergoing closure under approved RCRA closure plans. Closure plans for the remaining five sites are currently under regulatory review.

In September 1989, the SRS received regulatory approval of the RCRA Facility Investigation (RFI) Program. Unit-specific work plans will be developed for these units to determine the nature and extent of potential releases of hazardous substances and the necessity for corrective actions, if any. The RFI Program has integrated CERCLA requirements and is now known as the RFI/Remedial Investigation (RI) Program.

\section{Programs}

\section{Closure Activities/Phases}

Waste site closure activities include many phases, such as characterization, assessment, closure plan development, site closure, and remedial activities (see Figure 3.1).

Funding estimates of most of the waste sites assume the waste would be left in place with closure techniques, such as capping, applied. However, the final closure option is dependent on site-specific conditions and regulatory requirements and approval. 


\subsection{PRIMARY SITE-SPECIFIC OBJECTIVES BY PROGRAM}

- Characterization---Characterization of SRS waste units addresses:

- Compiling all available data

- Identifying data gaps

- Gathering additional information such as soil gas surveys, soil borings, well installations, and groundwater analysis.

- Assessment--SRS waste units are assessed as follows:

- Compiling and interpreting data collected during the characterization phase

- Identifying applicable regulations

- Developing closure plans.

Site-specific assessments include the following:

- Establishing the properties of the known contaminants, if any

- Determining the sources

- Ascertaining the rate and extent of contamination

- Identifying the groundwater flow directions and elevations.

Based on this information one or more closure options is recommended.

- Site Closure Criteria--Procedures and criteria for characterizing, remediating, and closing the inactive waste sites are controlled by applicable federal and state regulations and DOE orders. There is a minimum amount of information that must be developed for each site. A different level of activity is required at each waste site due to the type of waste deposited and the requirements of different regulations. The definition of the unit-specific closure criteria is developed during the characterization and assessment of phases of closure for each site.

- Closure Plan Development and Approval--The closure plans for all SRS waste sites will be developed to minimize or eliminate the migration of contaminants. This plan may be obtained by immobilization or extraction of the contaminant or by capping the waste site without contaminant removal. Closure plans address the following:

- Obtaining agreement on closure performance standards

- Establishing a detailed waste inventory

- Determining waste removal, treatment, and disposal requirements

- Determining sampling and analysis needs

- Defining backfill requirements

- Identifying cover systems

- Decontaminating equipment

- Controlling surface water

- Establishing closure schedules. 
- Postclosure/Remedial Action Plan Development--An integral part of each waste site closure plan is the post closure maintenance and monitoring activities to ensure integrity and security of the closed waste site. Postclosure plans include the following:

- Developing inspection checklist

- Defining inspection frequency

Postclosure/remedial action plans for specific waste sites must be reviewed and approved by the appropriate regulatory agencies.

- Closure--The major portion of work outline in the closure plan will be performed by subcontractors. The waste site custodian is responsible for managing the subcontractor(s) and ensuring that the contractor is following the approved closure plan.

- Postclosure Activities/Remedial Action--ER is responsible for ensuring the implementation of the activities specified in the approved Postclosure/Remedial Action Plan. Postclosure inspection, maintenance, and monitoring may be required following closure in order to ensure the integrity and security of the closed waste site. The effectiveness of any required remedial actions is verified through postclosure monitoring. The scope of these activities will vary from site to site depending on the type and amount of waste, waste residue, or residual contamination remaining in place following site closure.

\section{Decontamination and Decommissioning (D\&D)}

No primary objectives or milestones for decontamination and decommissioning were listed in the Environmental Restoration and Waste Management Five Year Plan, FY 1991-1996.

Near-term objectives to be reached in FY 1991 are to:

1. Prepare a D\&D plan for FY 1992-1993.

2. Complete the survey of custodians for potential D\&D projects.

3. Participate in establishing DOE facility acceptance criteria.

4. Prepare D\&D sites for acceptance into the program.

\subsection{Waste Management Operations}

\subsubsection{Introduction}

Waste Management Activities is defined as the management of all types of waste (DOE 1989). Radioactive waste is categorized according to how it must be dealt with and managed according to standards established by the EPA and specified DOE orders. Highlevel waste (HLW) requires considerable shielding, is long-lived and will be disposed of in a geologic repository. Low-level waste (LLW) is defined as that radioactive waste that is not HLW. LLW is normally solid waste that is containerized according to its radioactivity and disposed of onsite. The TRU waste generated onsite generally requires little shielding, is extremely long-lived, and will also be disposed of in a federal geologic repository. Hazardous waste is defined by several environmental laws and managed according to 
requirements established by the EPA and states. Mixed waste is waste that contains both radioactive and hazardous components. It is managed to meet requirements for its radioactive and hazardous components imposed by the EPA, states, and DOE. Sanitary waste, which is neither radioactive nor hazardous, is also within the scope of the FYP and is managed according to established federal and state regulations (DOE 1989a).

The SRS Waste Management practices are regulated by the DOE, EPA, and SCDHEC. RCRA, also known as the Solid Waste Disposal Act, as amended, provides a comprehensive EPA regulatory program for hazardous waste management and a state regulatory program for nonhazardous wastes. The SCDHEC has been granted authority by EPA to conduct the RCRA hazardous waste program in South Carolina. The basic framework for the management of hazardous waste, from its generation to its final disposal, is presented in 40 CFR 260-280.

All hazardous waste treatment, storage, and disposal facilities at the SRS are either: (1) fully pernitted, (2) have interim status, or (3) have entered into settlement agreements or consent orders with the SCDHEC. The SRS is in compliance with or has entered into compliance agreements related to groundwater protection, waste treatment, and waste disposal regulations. Several RCRA settlement agreements and consent orders have been signed from 1985 to November 1990 (see Section 2.5).

Some of the facilities needed for treating, storing or disposing of the wastes are currently in operation; others are in active design or construction; still others are in the conceptual planning stage.

The SRS Waste Management objectives are to comply with applicable federal and state regulations, DOE Orders and WSRC policies, to minimize effects on the environment, minimize the generation of waste, and, to the extent possible, contain waste handling, treatment, storage, and disposal within the site. Exceptions to onsite final disposal are PCBs, which must go to EPA-approved PCB disposal facilities; high-level wastes and TRU wastes, for which federal repositories are to be designated; some types of nonradioactive hazardous waste, which are sent offsite for incineration and disposal until onsite facilities are available; chlorinated hydrocarbons, lead batteries and scrap metal, which are sold to commercial recyclers. SRS also sells salvage: miscellaneous electrical components, drums, paint, miscellaneous pipes and weld rod stubs.

The strategy for achieving SRS Waste Management objectives is to:

- Ensure that there is a method to dispose of the waste, before the waste is generated.

- Reduce/minimize waste generation.

- Recycle/reuse consumed wastes in processes as much as practical.

- Segregate waste at point of generation such that uncontaminated waste or hazardous waste does not become radioactively contaminated.

- Segregate wastes at the generating location for temporary storage in permitted facilities as required. 


\section{BY PROGRAM}

- Incinerate to destroy hazardous wastes and reduce waste volume.

- Treat wastes to minimize mobility before final disposal.

- Dispose of newly generated wastes ultimately in monitored repositories.

- Maintain integrity of existing disposal sites to ensure performance objectives are met.

The major categories of wastes generated at the SRS are sanitary, hazardous, mixed (hazardous and radioactive), low-level radioactive, high-level radioactive and transuranic. Within each of these six categories there is a multitude of waste streams requiring numerous storage and disposal techniques.

As part of the Waste Management objectives, the Waste Minimization Program has been implemented. The Waste Minimization Program is an organized, comprehensive, and continual effort to systematically reduce waste generation. The Waste Minimization Program is designed to eliminate or minimize pollutant releases to all environmental media from all aspects of the site's operations. The program meets regulatory and WSRC requirements. The Site Waste Minimization group has been assigned responsibility for coordinating the development, promotion, implementation, and reporting of waste minimization activities.

The Waste Minimization Program implements specific waste minimization techniques and technologies based upon accurate and current information on waste generation, waste characterization, and ultimate waste disposal costs. The program will develop guidelines for collecting information, evaluating options, and identifying cost-effective waste minimization techniques.

The objectives of the Waste Minimization Program are to:

- Foster a philosophy to conserve resources and create a minimum of waste and pollution in achieving strategic objectives.

- Promote the use of nonhazardous materials in all activities to minimize the potential risks to human health and the environment.

- Reduce or eliminate the generation of waste materials through substitution, product redesign, process modifications, improved housekeeping, and recycling to achieve minimal adverse effect to the air, water, and land.

- Enhance communication of waste minimization objectives, goals, and ideas laterally and vertically among site organizations.

- C'naracterize waste streams and develop a baseline for waste generation data.

- Identify and implement methods and technologies for waste minimization. 
The Site Waste Minimization Plan is WSRC-RP-90-263, Department of Energy SRS Waste Minimization Plan, Rev. 3.

\subsubsection{Description of Activities}

\subsubsection{Power}

Wastewater from Building 784-A Powerhouse was discharged to A-008 outfall until thie fall of 1989. At that time, it was decided that because A-008 is not permitted under the NPDES, the discharge must be ceased. Since November 1989, Powerhouse wastewater has been collected in a tank, transferred to a tanker truck, and transported to the D-Area ash basin for disposal.

Project S-3072 provides for treatment of Building 784-A wastewater for the re-routing of the treated waste stream to A-011 outfall, which is permitted un . $r$ NPDES. The project will neutralize the high $\mathrm{pH}$ boiler blowdown waste stream. It wul combine with the coai unloading sump waste stream, water used to was down the powerhouse, and cooling water for the pumps. These combined streams will tlow through a clarifier for suspended solids removal, and then flow to a cooling tower. The cooling tower discharge will combine with service and domestic water tank overflows and well blowoff prior to discharging to A-011 outfall.

\subsubsection{Reactor Materials}

The Reactor Materials (RM) program is responsible for providing fuel and targets to support the SRS reactor operations. These activities must comply with Federal and State environmental regulations, the DOE orders and Tiger Team findings, and SRS waste management goals. (The Tiger Team is an independent oversight group formed by the Secretary of Energy, Admiral James D. Watkins, to conduct assessments of the Environment, Safety, and Health programs at DOE facilities.)

The major activities associated with waste control and management that are needed to accomplish the RM mission are divided into the general categories of air effluents, solid wastes and wastewater effluents. The primary air effluent activities are the replacement of operations using chlorofluorocarbons (CFC) especially degreaser operations and the installation of improved radioactive air emissions monitoring systems. The primary solid waste activities are the operation of the $313-\mathrm{M}$ waste compactor; the excess chemical and material disposal program; the waste Filtration and Stabilization Facility (FIST) project; and the operation of two hazardous waste storage facilities: the Process Waste Interim Treatment/Storage Facility (IT/SF) and the Mixed Waste Storage Shed (MWSS). The primary waste water activities are the Liquid Effluent Treatment Facility (LETF) operations, the wastc water effluent toxicity reduction study, the M-Area process sewer repair and replacement program, and the M-Area storm sewer upgrade program. A short description of these activities is found in the following paragraphs. 


\section{BY PROGRAM}

\section{Air Effluent Activities}

New Degreaser System--The system in Building 321-M used for degreasing metal components and products will be replaced with a system which uses non-hazardous degreasing agents which will eliminate CFC air emissions. CFCs are an international environmental concern, and production will soon stop per regulatory requirements. Methods to eliminate CFC degreasing or the use of alternative materials are being developed. This program is being developed with the assistance of the SRL. The new degreasing agent is expected to be aqueous based. In conjunction with this program, the other operations using CFCs in M Area are being evaluated for the elimination of CFC usage.

Radioactive Air Emissions Monitoring--Two projects are currently in place to upgrade the monitoring of radioactive air emissions from Building 321-M. Both projects will provide monitoring systems which will comply with existing environmental regulations and the DOE orders. Project S-2700 will install additional and improved air emissions control and monitoring equipment for the billet heating ovens. Project S-2792 will install upgraded air monitoring systems to the remaining Building 321-M process stacks.

\section{Solid Waste Activities}

Building 313-M Waste Compactor Operations--The purpose of the waste compactor is to reduce the volume of low-level radioactive and mixed solid waste generated in M-Area and sent to Waste Management (WM) for disposal and storage. The compactor primarily processes material from $M$-Area production and was: management facilities, but occasionally processes waste from other site facilities into B-25 boxes (rigid steel containers). The unit is equipped with air pollution control and monitoring equipment to control and measure radioactive air emissions.

Excess Chemical And Material Disposal Program--The purpose of the excess chemical and material disposal program is to remove materials which are no longer used from the M-Area inventory. The preferred disposal routes by priority are to return them to the original supplier; provide to alternate users on or off site; determine and use in an alternate manner from originally intended use; dispose of in M-Area; dispose of onsite; and dispose of off-. site. This program also disposes of M-Area material and waste streams which are amenable to either on or offsite recycle or recovery.

Waste Filtration And Stabilization Facility (FIST) Project--This project will pre-treat the concentrated waste sludge, a radioactive RCRA listed hazardous waste generated by Building 313-M operations, from the IT/SF tanks so that federal land ban regulations can be achieved when the sludge is solidified for final disposal. The treatment will involve filtration (with or without rinsing) of the concentrated solids in M Area. The filtered solids will be reslurried and sent for final stabilization and disposal. Excess liquid (filtrate) will be processed in the existing M-Area wastewater treatment facility. Figure 3.2 shows the FIST process that will to used. An alternative to this project is being investigated that would have the materia. . eated by a subcontractor similar to the above in lieu of installing the FIST Facility. 


\section{BY PROGRAM}

Waste Storage Facility Operations--Two hazardous waste storage facilities, the Process Waste Interim Treatment/Storage Facility (IT/SF) and the Mixed Waste Storage Shed (MWSS) are operated to accommodate unique wastes generated by the facilities in M-Area. The IT/SF stores hazardous wastewater treatment sludges in tanks ranging from 35,000 to 500,000 gallons. The supernate from these tanks is being processed through the M-Area wastewater treatment facilities to reduce the volume of the sludges that the FIST project will be required to process. The MWSS stores drummed mixed waste filter cake from previous Building 313-M operations.

\section{Wastewater Effluent Activities}

Liquid Effluent Treatment Facility (LETF) Operations--The purpose of the LETF operations is to treat wastewater effluent from M-Area operations to ensure compliance with National Pollutant Discharge Elimination System (NPDES) permit limits and prevent discharge of hazardous constituents (like uranium) to the environment. M-Area liquid effluents are processed by two facilities which compose the LETF: the Chemical Transfer Facility (CTF) located adjacent to Building 313-M and the Dilute Effluent Treatment Facility (DETF) in Building 341-M. The CTF processes concentrated chemical wastes from Building 313-M operations. The DETF processes all $\mathrm{M}$-Area process rinse waters and supernate from the IT/SF tanks, and discharges environmentally acceptable liquid effluent to an NPDES outfall. CTF slurry and DETF filter cake are stored in the IT/SF tanks subsequent to final treatment and disposal.

Wastewater Effluent Toxicity Reduction Study--M-Area is permitted to discharge treated industrial wastewater (Outfall M-004) and groundwater from the permitted air stripper operation (Outfall M-005). These discharges are combined with M-Area noncontact cooling water and storm water at Outfall A-014. As part of the NPDES permit renewal, SCDHEC is expected to include routine chronic toxicity tests of Outfall M-004 as part of the permit conditions. Toxicity tests have been added to the regulatory requirements of the Clean Water Act. Scouting tests have indicated that Outfall A-014 may fail the anticipated toxicity tests at its instream concentration. Wastewater toxicity assessments and toxicity reduction process development will be necessary to comply with the new regulatory requirements.

Process Sewer Program--In one of the DOE Tiger Team assessments (SW/BMP-1) the MArea process sewer was referenced for the leaks it had experienced. To address this finding, a program has been implemented to perform periodic inspections and repair the existing process sewer. In addition, a project has been initiated to install overhead process sewer lines from all facilities in M-Area to handle area wastewaters. The program's overall objective is to eliminate all underground process sewer lines.

Storn Sewer Program--This project will increase the existing system's capacity, which is operating at maximum capacity. The system will be modified to handle additional volumes of noncontact cooling water needed to support facility modifications and production requirements. The modifications will include contamination monitors to ensure compliance with new NPDES regulations for stormwater systems. 


\subsection{PRIMARY SITE-SPECIFIC OBJECTIVES} BY PROGRAM

\subsubsection{Reactors}

\section{Upgrade Disassembly Basin Water System}

The disassembly basin water filtration and deionizer systems will soon reach the end of their useful life. This project provides this equipment for $\mathrm{K}$ and $\mathrm{L}$ Areas. P-Area equipment should be removed from this project.

\section{Waste Handling}

Waste handling costs include labor and materials for boxing and shipping reactor wastes and collecting and shipping wastewater and oil.

\subsubsection{Separations}

Waste Management operations in Separations consist of activities ranging from treatment, handling, and storage to disposal operations. Waste management treatment activities in operating facilities include packaging and handling of low-level, intermediate-level and TRU waste. Costs include materials for packaging (drums, boxes, plastic bags, and tape) and manpower costs to handle and load waste for proper disposal.

Two projects are planned to facilitate the loading and unloading of radioactive waste. One is to replace an existing radioactive waste truck unloading facility with an enclosed, contained facility for trucks bringing high- and low-level wastes to F-Area processing facilities. The other project will be to construct an addition to the existing dock for loading of regulated waste from FB-Line and New Special Recovery (NSR) facilities.

Installation of analytical instrumentation for screening low-level waste prior to removal from the FB-line facility is planned along with a new facility for processing TRU solid waste; operations including assay, compaction, certification, and preparation of material for recovery in NSR.

A storage facility that would meet RCRA standards for uranium trioxide powder is also being planned.

To eliminate the potential for release of contaminated cooling water to an NPDES permitted outfall, an automatic low background Alpha/Beta/Gamma counting system will be purchased and installed in the 221-H HP counting room. The present method used to determine the activity in the segregated cooling water is adequate but will be improved with this project.

\subsubsection{Tritium Facility}

Tritium's waste management operation activities are an integral, on-going part of normal Tritium Facilities production activities. Waste managcment activities include identification, handling, packaging, short-term storage, and shipment of job-control (low-level radioactive), mixed, and hazardous waste. Waste volume reduction of low-level job control waste by compaction is an important part of Tritium's waste management program. 


\section{BY PROGRAM}

Waste minimization is also part of Tritium Facility's waste management activities. Material substitution, procedural control of material entering radiological controlled areas, and revised work practices to eliminate the use of hazardous materials are all elements of Tritium's waste minimization effort.

The bulk of waste generated in the Tritium Facilities is low-level radioactive solid waste. This waste is either compacted or sent to the Solid Waste Disposal Facility, E Area, in B25 burial boxes for land disposal. The source of this waste is usually job control waste (shoe covers, plastic, paper, gloves, etc.) or material generated from equipment or facility destruction and removal (D\&R) work. Mixed and hazardous waste streams are managed in RCRA satellite or staging areas. Tritiated mercury, tritiated oil from pumps and compressors downstream from mercury diffusion pumps, suspect toxir waste, and F-listed solvent rags are managed in these RCRA accumulation areas.

Low-level liquid waste from radiograph developers and metal grinding operations is sent to Effluent Treatment Facility (ETF) for cleanup and disposal.

\subsubsection{Waste Management}

\subsection{High-Level Waste Management}

High-Level Waste (HLW) is defined as the highly radioactive waste material that results from the reprocessing of spent nuclear fuel. This includes liquid waste produced directly in reprocessing and any solid waste derived from the liquid. The HLW contains a combination of transuranic waste and fission products in concentrations requiring permanent isolation. Figure 3.3 shows the process flow diagram for the SRS high-level waste management plan.

SRS liquid waste, as received in the waste tanks, is made up of many waste streams generated during the recovery and purification of transuranic products and unburned fissile material from spent reactor fuel elements. These wastes are neutralized to excess alkalinity (pH 10 to 13) before transfer to the million-gallon underground storage tanks.

HLW is separated into the F- and H-Area Canyons according to radionuclide and heat content. High-heat waste (HHW) is primarily generated during the first extraction cycle in the separations canyon and contains a major portion of the radioactivity. Low-heat waste (LHW) is primarily generated from the second and subsequent extraction cycles in the canyons. HHW is aged at least a year in receipt tanks to reduce the concentration of shortlived radionuclides before evaporation.

\section{Waste Tanks}

Waste Management operates 51 waste tanks and 4 evaporators for the purpose of safely storing and processing liquid radioactive waste. The major waste streams into the F- and H-Area tank farms include HHW, LHW, and DWPF recycle. Other major miscellaneous inputs internal to the tank farm include additions and byproducts of processes required for 
preparation of DWPF feed such as sludge wash water, sludge removal decant, spray washing, inhibitors, and caustic used for aluminum dissolution.

Of the 51 tanks, 29 are located in the $\mathrm{H}$-Area tank farm and the remainder are located in $\mathrm{F}$ Area tank farm. All of the tanks were built of carbon steel and reinforced concrete, but they were built with four different designs. The newest design (Type III) has a full-height secondary tank and forced (water) cooling; two designs (Types I and II) have five-foothigh secondary pans and forced cooling; the fourth design (Type IV) has a single steel wall and does not have forced cooling. Type IV tanks have been used in the past for HLW receipt. The majority of the waste in Type IV tanks has already been transferred to Type III tanks, which are the preferred tanks. The tanks will continue to be used for low-activity waste streams until they are replaced by the Hazardous Low-Level Waste Processing Tanks, an FY 1991 waste processing line item.

\section{Evaporators}

Each waste tank farm has two single-stage, bent-tube evaporators that are used to concentrate waste following receipt from the canyons. High-heat waste is segregated and allowed to age before evaporation. The aging allows separation of the sludge and supernate and also allows the shorter-lived radionuclides to decay to acceptable levels. Low-heat waste is sent directly to an evaporator feed tank. The sludge settles to the bottom of the feed tank, and the supernate can be processed immediately through the evaporator. Salt crystallized from high-heat waste and low-heat waste is also segregated in separate tanks because the high-heat waste must be stored for a number of years (up to 12 years) to allow decay of ${ }^{106} \mathrm{Ru}$ before DWPF processing. The low-heat waste can be processed in 0 to 3 years.

Radioactive waste, as received and stored in the tank farms, can be reduced to about $25 \%$ of its original volume and immobilized as crystallized salt by successive evaporations of the liquid supernate. Such a dewatering operation has been carried on routinely in F Area since 1960 and in $\mathrm{H}$ Area since 1963. Since the first evaporator facilities began operation in 1960, more than $98,489,000$ gallons of space has been reclaimed. Seventy additional waste tanks valued at more than $\$ 50$ million each would have been required to manage this waste had evaporation not been used.

Three evaporators process low-heat waste: $242-\mathrm{F}, 242-16 \mathrm{~F}$, and $242-16 \mathrm{H}$. The $242-\mathrm{H}$ evaporator processes high-heat waste. Another evaporator, the Replacement High-Level Waste Evaporator (RHLWE), is being constructed to replace the $242-\mathrm{H}$ evaporator, which cannot be reliably maintained. The new evaporator will have approximately twice the capacity of the $242-\mathrm{H}$ evaporator that it replaces and will be able to accept the DWPF recycle (a low-heat waste stream of about three million gallons per year that contains very little solids) in addition to the high-heat waste. The additional capacity of the RHLWE should allow SRS to minimize operation of the 242-F evaporator, another old evaporator that is difficult to maintain. The RHLWE is scheduled to be online by June 1994. 
Each tank farm evaporator, except for the $242-16 \mathrm{~F}$ evaporator, has a cesium removal column located in a riser through the top of a waste storage tank. The $242-16 \mathrm{~F}$ evaporator has an improved de-entrainment unit that is efficient enough to eliminate the need for a Cesium Removal Column (CRC). These columns are used to remove cesium from the condensate that results from the concentration of waste supernates. In addition, one of the columns in $\mathrm{H}$ Area is used, if needed, to remove cesium from aqueous wastes discharged by the resin regeneration facility (RRF) and the receiving basin for offsite fuel (RBOF). When the evaporator overheads are below a prescribed radioactivity level, they are sent through the cesium removal column to further reduce the Cs-137 content. If the Cs-137 concentration in the overheads is above the prescribed level, the waste stream is recycled for additional evaporation. The evaporators achieve a condensate decontamination factor of greater than $10^{4}$. The cesium removal columns ion exchange resin can provide a decontamination factor for Cs-137 of up to 200. The cesium removal column effluent is sent to a hold tank where it is sampled, and if the concentration is acceptable the processed condensate is sent to the ETF. It may also be sent to a waste tank.

\section{Waste Transfer System}

The primary objectives of the High-Level Waste Transfer and Processing Program are to transfer radioactive waste, including liquid, salt, and sludge from the first three generations of waste tanks (Types I, II and IV) into newer Type III tanks, to maintain space in the tank farms for fresh waste receipts from the separations facilities by removing salt cake stored in Type III concentrate receipt tanks and to prepare this waste (and eventually the remainder of the waste in the Type III tanks) for feed to the DWPF. The waste removal program includes removal of salt and sludge by mechanical agitators, spray washing of the tank interior walls, and steam/water cleaning of the tank annuli. The waste processing program includes decontamination of the salt and liquid for incorporation into saltstones and aluminum dissolution and washing of the sludge for feed to the DWPF.

The schedules of waste transfer and waste processing are closely linked to each other and with the DWPF schedule. The scheduling objective is to remove the waste from the Types I, II, and IV tanks as rapidly as possible without exceeding the capacity of the tank farm processes or the DWPF.

Processes and equipment for waste removal and waste processing have been developed and demonstrated. Sludge removal by hydraulic slurrying and chemical cleaning with oxalic acid have been demonstrated in Tank $16 \mathrm{H}$. Salt removal and sludge removal using mechanical agitation have been demonstrated. Facilities have been designed using data and experience gained from these demonstrations. To date, 3.4 million gallons of salt and 1.1 million gallons of sludge have been removed from Types I, II, and IV tanks.

To assist Waste Management with the Salt Removal Process, a new control system will be added to both F- and H-Areas tank farms. The control system consists of an operator's console, a maintenance console, and support peripherals. Both the operator and maintenance consoles will have the ability to function as the online console at the same 
time. The console that is not performing control will be able to monitor the logic executed in both the Instrument Control Room and field units.

The New Waste Transfer Facility (NWTF) is currently under construction on the south side of the H-Area tank farm and is intended to enhance the High-Level Waste Transfer and Processing Program. It is scheduled to begin operation in late 1992. The NWTF will replace another facility (HDB2) by providing for the transfer of radioactive slurries and solutions in $\mathrm{H}$ Area. It will also serve as the receipt point for recycle waste transfers from the DWPF.

\section{Sludge Processing}

Sludge that is removed from waste tanks is washed in Sludge Processing to reduce the concentrations of soluble salts from the sludge befor: it is fed to the DWPF. Sludge processing includes four processes: 1) aluminum dissolution (as required for $\mathrm{H}$ Area HHW) with sodium hydroxide and steam heat, 2) washing with inhibited water to remove dissolved solids, 3) gravity settling, and 4) decanting the salt solutions back to the tank farm for processing. Before washing, H-Area HHW sludge is mixed with sodium hydroxide to dissolve aluminum. Quantities of aluminum in other waste tanks are not sufficient to require aluminum dissolution. After aluminum dissolution, two tanks will be used to wash sludge concurrently, with the wash water from the first tank being reused to wash the sludge in the second. When washing is complete, the sludge is transferred to one tank to be fed to the DWPF; then, processing begins again using a third tank for coprocessing. Four slurry pumps supply the agitation for washing. Wash water that results from this process will either be transferred to an evaporator system or stored for reuse in dissolving saltcake, depending on the sait concentration. Tank 21, a Type IV tank, will be used for staging this low activity wash water until the Hazardous Low-Level Waste Processing Tanks (HLLWPTs) are available for use.

\section{In-Tank Precipitation}

Salt will be removed from the waste tanks and processed via ITP. ITP extracts the majority of the radionuclides in the form of thick white precipitate; the material is then fed to the vitrification process in the DWPF. Radionuclides are removed by adding sodium tetraphenylborate (STPB) and sodium titanate (ST) to the ITP feed tank to precipitate cesium (and potassium) and adsorb strontium, respectively, from the dissolved waste salt solution. After filtration, the precipitate is washed with water, concentrated to $10 \mathrm{wt} \%$, and transferred by batch to the feed tank for the vitrification facility. The wash water is collected and recycled into the next cycle of ITP. The decontaminated salt solution (filtrate) will be stored separately and fed to Saltstone. ITP will process $1,500,000$ gallons of saltcake annually resulting in 300,000 to 500,000 gallons of precipitate and about $7,500,000$ gallons of filtrate each year.

\section{E/HEffluent Treatment Facility (ETF)}

Low-level aqueous streams currently sent to the F/H ETF from the 200 Areas consist of: segregated cooling water, contaminated surface runoff from the waste tank farms, laundry waste, certain evaporator overheads, cesium removal column effluent, condensate from the general purpose evaporator and acid recovery units located in Building 211 , selected liquid 
regeneration wastes from the resin regeneration facility in $\mathrm{H}$ Area, water collected in $\mathrm{H}$ Area catch tank from transfer line encasements, and cooling water from the tritium facilities. Figure 3.4 shows the process flow diagram for the SRS F- and H-Area Effluent Treatment Facility waste management plan.

The F/H ETF treats the waste water that was previously sent to seepage basins. The treatment process includes filtration, organic removal, reverse osmosis, and ion exchange. The facility consists of process wastewater tanks, treated water tanks, basins to collect contaminated cooling water and stormwater runoff and a water treatment facility.

Facilities had not previously been available for treating all types of contaminated water releases from the canyons nor were there facilities to send contaminated water in the retention basins to the tank farms for storage and/or treatment via the tank farm evaporators. The F/H ETF corrects this by providing treatment facilities for all types of low-level wastewater.

\subsection{Low-Level Solid Waste Management}

Solid waste materials that have become contaminated with beta-gamma and/or very low levels of alpha radioactivity are defined as low-level waste. Waste contaminated with betagamma emitters is separated into two categories for land disposal: low-level and intermediate-level. Figure 3.5 shows the process flow diagram for management of the SRS low-level and Intermediate-level waste management plan.

\section{Low-Level Waste}

Low-level solid waste is defined as waste that radiates less than $300 \mathrm{mrads} / \mathrm{hr}$ or $300 \mathrm{mR} / \mathrm{hr}$ at three inches from an unshielded container and contains less than $10 \mathrm{nCi} / \mathrm{g}$ of TRU contaminants. Low-level waste is generated by SRS Laboratories, Raw Materials, Reactors, Separations, Site Services, SRL, Tritium, and Waste Management Departments. The following materials are examples of solid low-level waste that are routinely handled:

- Operating and laboratory waste: small equipment, protective clothing, analytical waste, decontamination residue, plastic sheeting, gloves.

- Contaminated equipment: obsolete or failed tanks, pipe, jumpers, and naval hardware.

- Reactor and reactor fuel hardware: irradiated fuel components and housings not containing fuel.

- Spent lithium-aluminum ( $\mathrm{Li}-\mathrm{Al}$ ) targets: the irradiated $\mathrm{Li}-\mathrm{Al}$ alloy from which tritium has been extracted.

- Spent deionizer resin from reactor areas.

Cardboard and fiberboard boxes are no longer used as final disposal containers for packaging solid radioactive waste for shallow land disposal. Rigid metal containers are now lised in most cases to obtain greater trench utilization through container stacking. 


\subsection{PRIMARY SITE-SPECIFIC OBJECTIVES BY PROGRAM}

The following containers are used for waste burial:

- 55-gallon drums,

- 90-cu-ft metal boxes (B-25s) and 45-cu-ft metal boxes (B-12s), and

- Engineered steel boxes designed and approved by the Waste Management Department.

Waste generators currently use rigid containers for all waste except building debris, soil, and other bulky material that does not fit in standard containers. These wastes are still shipped to the burial ground in a noncontainerized form.

Low-level radioactive waste volumes are being reduced by compaction processes in $\mathrm{H}$ Area (Building 253-H) and M Area. The B-25 container compactors are achieving volume reductions of 8 to $10: 1$ and are capable of compacting waste types typically placed in cardboard waste boxes. The Building 253-H compactor processes beta-gamma waste from the 200 Areas (Separations, Waste Management, Tritium) and from SRL (Building 773-A) with radiation rates of $50 \mathrm{mrad} / \mathrm{hr}$ or less. The M-Area compactor processes primarily uranium-contaminated waste from M-Area facilities.

Current programs to increase compaction efforts include compacting tritium-contaminated waste at Building 253-H and increasing utility of compactors by educating generators.

Waste Management has established the Landfill Monitoring Prograrn to monitor clean waste from regulated areas to verify that it can be sent to the sanitary landfill rather than to the solid waste disposal facility. Boxes containing less than $10 \mathrm{nCi}(0.00000001 \mathrm{Ci})$ per box are sent to the landfill. Those containing greater than $10 \mathrm{nCi}$ per box are sent to the compactor prior to disposal in the solid waste disposal facility. The program began as a pilot operation in February 1987, and the Landfill Monitoring Facility was turned over for operation in November 1987.

One centrally located site is used to store or dispose of all radioactive solid waste produced at the SRS as well as DOE shipments from offsite (Figure 3.6). This site, known as the Solid Waste Disposal Facility (SWDF), E Area, occupies 195 acres between the F and H Separations Areas, approximately six miles from the nearest plant boundary. The original area of 76 acres (Building 643-G), which began to receive waste in 1953, was filled in 1972 , and operations were shifted to a 119-acre site contiguous to the original area (Building 643-7G). In 1986, a portion of the 119-acre site was closed and designated as Building 643-28G (also known as the Mixed Waste Management Facility, MWMF) when it was determined to contain potentially hazardous waste. A closure plan was submitted to and approved by SCDHEC. Truck access to the disposal or storage facilities is provided by a paved road and many unpaved roads inside the fenced area. Railroad spurs permit shipments of large pieces of contaminated process equipment from the operating areas.

The relatively level land and the specially selected Bahia grass cover effectively control surface erosion at the storage and disposal site. Surface drainage ditches channel the runoff of rainwater (47 inches each year) to provide further erosion control. Soils underlying the storage site consist of nearly a thousand feet of mostly unconsolidated sands, clayey sands, sandy clays, and clays. The principal surface and near-surface soils are clayey sands 
averaging about one-third clay. These soils have a high ion exchange or other retention capacity for most elements, including plutonium, cesium, and strontium. Tritium mobility is not affected by the soils.

The mean water table is at a depth of about 45 feet. During a normal year, the fluctuation across the mean level is about 2 feet; the extreme variation noted was in 1960 when the water table rose about 7 feet above the normal mean.

In addition to the solid radioactive wastes deposited there, SWDF 643.-7G has provided interim storage for radionctive degraded organic solvents (tributylphosphate in kerosene or $\mathrm{n}$-paraffin) in eight separate 24,600-gallon underground storoge tanks (S23-S30). Before these 8 tanks were put in use, 22 tanks in $643-\mathrm{G}$ were used for solvent storage. Tanks S1S22 are essentially empty except for the sludge and liquid heels in some of them.

The primary disposal mode for solid radioactive waste is burial in engineered earthen trenches. Criteria for selection of trench sites include:

- Groundwater table at least 10 feet below the bottom of prospective trenches.

- Absence of perched groundwater tables that would cause leaching of buried waste.

- Soil containing enough clay to maintain the integrity of the excavation walls without support.

- Topography conducive to level trenching and controlled surface water runoff.

A typical Engineered Low-Level Trench (ELLT) is about 22 feet deep, with the other dimensions adjusted to maximize the available space. The walls of the trench are sloped to prevent cave-ins, and a ramp allows access by waste shipment trucks. Waste boxes are offloaded and stacked by an extendable-boom forklift.

The trench floor is sloped slightly to one side and end, so that rainwater will run into a sump located at the low corner of the trench. The sump is used to eliminate the potential for standing water while the trench is being filled. Rainwater is monitored to confirm that no contamination exists before it is released to surface drainage. If contamination is detected, the liquid will be disposed of via the plant liquid waste handling system.

Since the waste boxes are now stacked instead of dumped as in conventional trenches, the ELLT has much more efficient space utilization. Since there is no need for the 10 feet of soil between conventional trenches, the amount of land available for waste disposal has been increased as well. The space between the sloped walls and the stacked wasteboxes may be used for disposal of 55-gallon drums, bulky containerized waste, and contaminated soil.

\section{Intermediate-Level Waste}

Intermediate-activity beta-gamma waste measures $>300 \mathrm{mrads} / \mathrm{hr}$ or $>300 \mathrm{mrems} / \mathrm{hr}$ or $>300 \mathrm{mR} / \mathrm{hr}$ at 3 inches from the unshielded container and $<10 \mathrm{nCi} / \mathrm{g}$ of TRU 


\subsection{PRIMARY SITE-SPECIFIC OBJECTIVES BY PROGRAM}

contamination. Waste with low radiation rates and tritium contaminants that have the potential for offgassing is buried as intermediate-activity waste.

Trenches for disposing intermediate-level and bulky noncontainerized low level (alpha and beta-gamma) and containerized offsite wastes, are excavated $6 \mathrm{~m}$ wide, $6 \mathrm{~m}$ deep, and up to $300 \mathrm{~m}$ long and are called slit trenches. Wasteforms emplaced in the slit trenches are covered with soil shortly after emplacement to maintain radiation control and reduce potential for contamination spread. Ultimately, all trenches filled with waste are backfilled with a minimum of $1.2 \mathrm{~m}$ of soil to reduce surface radiation rates to less than $5 \mathrm{mrem} / \mathrm{hr}$, to reduce the potential for contaminant spread, and to minimize plant and animal intrusion into the waste.

Most wasteforms generated offsite are buried in slit trenches, or stacked in ELLT-4 as required to optimize burial space. Some U.S. Navy submarine reactor components are stored above grade and covered with soil.

A method for improving the disposal method for intermediate-level waste was developed using demonstration projects. The demonstrations, entitled greater confinement disposal (GCD), provide a method for encapsulating the waste in concrete/grout and monitoring the solidified wasteforms for water leaching of any radionuclides.

The objective of GCD is to provide a near-zero release facility that will require minimum maintenance after closure for disposal of the higher activity fraction of the low-level solid beta-gamma waste and low-level alpha waste. The methods employed to meet this objective are deeper burial to prevent root and animal intrusion and stabilized wasteforms.

Twenty 9-foor-diameter boreholes have been augered to a depth of about 30 feet. Nineteen boreholes contain a 20-foot long, 7-foot-diameter fiberglass liner with a fiberglass bottom, while the remaining borehole contains a 20 -foot-long, 7 -foot-diameter steel liner. A steel collar lines the top 10 feet of each borehole to prevent soil from sluffing off into the borehole. The fiberglass liners, which can hold up to forty-two 55-gallon drums of waste, are grouted in place. Essentially all of the boreholes have been filled with waste.

All waste emplaced will be stabilized by placing grout around the wasteforms to fill void spaces. A one-to-two-foot-thick concrete cap will be poured in the top two feet of the liner. As each borehole is filled, the steel collar will be removed and the borehole will be backfilled above the waste monolith. After all of the boreholes are filled, the earth cover will be removed, and a clay cap will be formeci over the boreholes. Native clay will be added on top of the cap per a site closure plan that provides a design which will prevent root and animal intrusion and discourage future human intrusion.

Monitoring wells (dry wells) are placed in each borehole and around the perimeter 0 : the GCD site. Monitoring and modeling of the operation will proceed with waste emplacement.

A second method of GCD emplacement is the GCD-engineered trench (GCD-ET). This trench was constructed for the disposal of reactor scrap metal, spent melt crucibles, and the more bulky wasteforms. Success of this trench will depend on how the waste is packaged. Reinforced concrete forms the walls of the 4-celled, 1()()-foot-long, 5()-foot-wide disposal 


\section{BY PROGRAM}

trench. To minimize rainwater intrusion, steel covers are placed over each disposal cell when it is not in use. Also, drainage is provided to cliannel water away from the trench. A leachate collection system was installed below the floor of the trench to monitor the performance of the disposal cells. The first waste was placed in the GCD-ET in April 1987.

\section{Future Facilities}

Low-level waste generated at SRS and received from offsite DOE facilities remained at about one million cubic feet per year in FY 1990. At this rate, the existing burial ground (643-7G) will reach its capacity for intermediate-level waste and low-level waste by March 1992. In addition, current SWDF disposal practices (shallow land burial) are inconsistent with new DOE guidance and revised $5820.2 \mathrm{~A}$ performance requirements and current disposal concepts being proposed uy compact states for commercially generated low-level waste which emphasize the need for engineered barriers in conjunction with favorable site characteristics to isolate the waste from the environment.

A 100-acre site in the north portion of E Area is being developed to meet projected SRS solid low-level radioactive waste storage/disposal requirements for the next 20 years (Figure 3.7). The proposed site is located within E Area, which includes the radioactive waste burial ground, the Mixed Waste Management Faciiity, and the F- and H-Area seepage basins. This facility is being designed to meet the performance objectives of DOE Order $5820.2 \mathrm{~A}$, including the EPA proposed $4 \mathrm{mrem} / \mathrm{yr}$ effective dose equivalent for groundwater at the facility's perimeter.

The project will include site work (fencing, lighting, monitoring wells, railroad spur and siding, and access roads) and the initial waste storage/disposal units (intermediate level, low-level, long lived, and support equipment). All subsequent waste storage/disposal units will be provided by cost funds.

The current E-Area practice of dividing wastes into low- and intermediate-level fractions will be expanded to include new classifications as shown below. The four waste categories provide for the segregation and storage of tritiated and long-lived wastes which is necessary to meet the groundwater performance objectives of DOE Order 5820.2A. Initial disposal units will consist of below-grade, concrete vaults designed to have sufficient strength to withstand the stresses of final closure. The storage portion of the facility will consist of concrete vaults and storage buildings. Each waste category will be handled as follows:

- Intermediate Level Nontritium (ILNT) Waste will be disposed of in a total of ten belowgrade concrete vaults. The vaults will be further divided into seven cells, each measuring 25 feet long by 46 feet wide by 28 feet high. (The E-Area Solid Waste Disposal Facility [SWDF] Expansion project will provide the initial vault with two years capacity.) The waste will be delivered by trucks and emplaced by a mobile gantry crane designed to straddle the vault cells. Each cell will be protected by a removable metal rain cover. Wastes will be grouted in place to reduce the potential for 
contamination, minimize sky shine and provide a working surface for the next layer of wastes. This operation is essentially the same as the current GCD-engineered trench operation.

- Intermediate-Level Tritium (ILT) Waste will be stored in a new onsite radioactive waste storage and disposal facility by April 1992. The new site being developed will include a total of ten concrete, intermediate-level tritium (ITL), vaults over the lifetime of the facility ( 20 years). The initial vault will be 28 feet in diameter $\times 46$ feet wide $\times 50$ feet long, and will accommodate a number of different tritium wasteforms. All wastes will be packaged in metal containers prior to receipt at the disposal facility, and emplaced using a mobile gantry crane. The primary wasteform will be a cylindrical-shaped stainless steel crucible (20 feet long $x 18$ inches in diameter.) used in tritium recovery. These crucibles will be placed inside silos with the vault to provide shielding and contamination control. An open portion of the vault, covered with shielding fees, will be used to store nonstandard size containers and wasteforms.

Maintaining tritium waste in a dry environment is essential to meeting groundwater performance objectives for the long-term storage of this waste (100 years). The initial vault will contain a sump to remove the water accumulations, and a sheet metal raincover to maintain wasteforms in dry condition. The vault is to be constructed a minimum of ten feet above the 100-year historical high water table. A french drain or similar concept will provide a capillary break between the vault and surrounding soil to further reduce the potential of perched water in the vault.

- Low-Activity Waste (LAW) will be disposed of in twenty below-grade concrete vaults, each measuring 648 feet long $\times 145$ feet wide $\times 25$ feet high. Each vault will contain twelve 54-foot-wide cells, Vaults will be constructed on poured-in-place concrete pads with sidewalls. Precast concrete girders and ronf panels will support an 18 -inch-thick, poured-in-place concrete roof over each vault. The project will provide the initial vault, which will contain one year of capacity. Most low-activity waste will be delivered in 4 $\mathrm{x} 4 \times$ 6-foot steel boxes and will be stacked four high using an extendable boom forklift. All waste will be containerized. This operation is similar to the current ELLT Operation for low activity waste.

- Long-Lived Waste will be placed by forklift on a concrete pad enclosed by a $50 \times 50 \times$ 21 -foot-high metal building. The project will provide the first of seven buildings. Wastes will be containerized to prevent the release of contamination and provided with adequate shielding.

Currently, site preparation is completed and construction has begun on the expansion project.

The Waste Preparation Facility (WPF) project, currently scheduled as a FY 1994 line item, will provide for the design and construction of a centralized facility to prepare and package low-level solid waste for treatment at the Consolidated Incinerator Facility (CIF) or disposal or interim storage in the E-Area vaults. The project will provide facilities for material handling, sorting, size reduction, compaction, and waste stabilization. 
The primary objective of the WPF is to prepare waste that cannot be efficiently placed in the E-Area vaults as is because of its size or packaging. The WPF will facilitate the maximum use of space by size and volume reduction of contaminited, large equipment waste generated at SRS. The IVPF will maximize the usefulness of the CIF by segregating combustible and noncombustible waste, and size reducing large combustible wastes into forms suitable for CIF. The WPF will have the capability to provide a stabilized, high integrity wasteform consistent with the BGE plans and acceptance criteria.

The CIF will be built to treat various site-generated combustible wastes before final disposal and to reduc", the volume of the current inventory of wastes stored at SRS. The wastes to be treated will include wastes defined as hazardous by South Carolina Hazardous Waste Management Regulations and federal RCRA regulations, wastes contaminated with low levels of beta-gamma radioactivity, and mixed wastes that are both hazardous and lowlevel radioactive. The facility will not treat wastes containing dioxins or polychlorinated biphenyls (PCB's).

Facilities to be provided on the CIF project (Figure 3.8) consist of a main process building which includes an area for boxed waste receipt, boxed waste handling, a rotary kiln incinerating system including incinerator ash removal and offgas cleaning, and the necessary control room and support facilities. The rotary kiln primary combustion chamber will be used for the incineration of solids and various organic and aqueous liquid wastes. A secondary combustion chamber will also incinerate organic solvent wastes as well as destroy any remaining traces of hazardous constituents in the rotary kiln offgas. Offgas exiting the secondary combustion chamber will be cooled and treated by a wet offgas treatment system. Pollutants in the offgas will be removed to below regulatory limits before the offgas is discharged to the atmosphere. Liquid waste from the offgas system will be solidified in the proposed Y-Area Saltstone Disposal Facility. An area is provided for installation of an existing solidification process for incinerator ash. Facilities included on the project but remote from the main process building include a liquid waste storage area.

\subsection{Transuranic Waste Management}

TRU waste is defined as waste without regard to source or form that is contaminated with alpha-emitting transuranic radionuclides with half-lives greater than 20 years and concentrations greater than $100 \mathrm{nCi} / \mathrm{g}$ at the time of assay. The flow diagram for managing TRU waste can be found in Figure 3.9.

Currently, all suspect TRU waste containers are being stored on TRU pads (containers are normally 55-gallon drums but boxes of larger size may be used to contain bulky items). Per SR Order 5820.2A, the lower concentration limit for TRU waste is $>100 \mathrm{nCi} / \mathrm{g}$. SRS Waste Management Department is currently certifying $>100 \mathrm{nCi} / \mathrm{g}$ waste to meet the Waste Isolation Pilot Plant Waste Acceptance Criteria (WIPP-WAC). The TRU waste lower concentration limit was raised from $10 \mathrm{nCi} / \mathrm{g}$ to $100 \mathrm{nCi} / \mathrm{g}$ transuranics with the issuance of SR Order 5820.2 in November 1985. The fraction of retrievably stored TRU waste which is contaminated in the $10 \mathrm{nCi} / \mathrm{g}$ to $100 \mathrm{nCi} / \mathrm{g}$ range will ultimately be disposed of in $\mathrm{GCD}$.

Drums containing waste Contaminated ió $>10$ nCíg and $<0.5 \mathrm{Ci}$ total are placed directiy on the TRU concrete pads. Drums containing $>0.5 \mathrm{Ci}$ total are stored inside concrete culverts on concrete pads. 
TRU waste was originally buried in plastic bags and cardboard boxes in earthen trenches designated specifically for this waste. Beginning in 1965, TRU waste was segregated according to content, retrievable and nonretrievable, and additional containment was added for retrievable waste. Waste containing $\geq 0.1 \mathrm{Ci}$ per package was placed in prefabricated concrete containers and then buried. These retrievable containers were 6 feet in diameter by 6.5 feet high. Waste that did not fit into the prefabricated concrete containers (culverts) was encapsulated in concrete. TRU waste from SRL was buried in cubical concrete containers. Waste containing $<0.1 \mathrm{Ci}$ per package was buried unencapsulated in trenches designed for alpha waste.

In 1974, the storage procedures were modified to reflect new DOE criteria (DOE Manual Chapter 0511, entitled Radioactive Waste Management) governing retrievable storage of solid TRU waste. TRU wastes contaminated to greater than $10 \mathrm{nCi} / \mathrm{g}$ are now stored and protected from contact with water-saturated soil in containers that can be retrieved intact and free of external contamination for at least twenty years from the time of storage. Plywood boxes placed in 3/8-inch-carbon steel containers, or polyethylene-lined galvanized drums, are used as primary containers. Polyethylene-lined galvanized drums containing more than $0.5 \mathrm{Ci}$ are additionally protected by closure in concrete culverts. In the past, containers have been stored on a concrete pad and covered with 4 feet of earth. SRS is no longer covering the filled pads with a soil overburden to reduce the waste retrieval costs.

Recent changes to the TRU Waste Storage Facilities include construction of four additional TRU waste storage pads in the burial ground, and the imminent installation of protective structures over TRU pads storing vented waste containers. The additional storage pads were necessary due to the delayed start of the WIPP-WAC Protective structures are being added to prevent rainwater intrusion into vented TRU waste containers currently stored on the pads.

An RCRA Part B Permit Application is also being prepared for the TRU waste storage pads and the Experimental TRU Waste Assay Facility (ETWAF)/Waste Certification Facility (WCF). Practically all of the TRU waste placed on the TRU waste storage pads prior to January 1990 is suspected to be co-contaminated with hazardous constituents. This mixed waste is currently being stored under EPA interim status. In accordance with SCDHEC regulations, this permit must be submitted and approved by SCDHEC prior to November 8,1992 , for continued operation of the TRU waste storage pads. Pads $1-5$ will be permitted as miscellaneous units under 40 CFR Subpart $X$, and pads $6-13$ and the ETWAF/WCF will be permitted as container storage areas under 40 CFR, Subpart I.

\section{ETWAF}

Beginning in April 1986, newly generated waste was received into the $30 \times 50$-foot Experimental Transuranic Waste Assay Facility (ETWAF) phase of the WCF from TRU waste generating facilities. The WCF will handle newly generated as well as retrieved waste processed in the TRU Waste Facility (TWF) when it begins operation.

In the ETWAF, drums are first weighed and assayed using the TRU Waste Assay System to determine whether the waste is contaminated to a level greater than $100 \mathrm{nCi} / \mathrm{g}$ and to determine other information required by the WIPP Waste Acceptance Criteria (WAC). This information is documented for each drum and the records are retained. Drums that contain 


\subsection{PRIMARY SITE-SPECIFIC OBJECTIVES BY PROGRAM}

less than $100 \mathrm{nCi} / \mathrm{g}$ are segregated and will eventually be sent to low-level waste disposal $(<10 \mathrm{nCi} / \mathrm{g})$ or greater confinement disposal $(>10$ and $<100 \mathrm{nCi} / \mathrm{g})$.

Each drum greater than $100 \mathrm{nCi} / \mathrm{g}$ is then $\mathrm{x}$-rayed to verify that the contents meet the WIPPWAC. The contents of each drum are recorded on videotape and the results of the $x$-ray are also recorded.

Diums that do not meet all WIPP-WAC are either returned to the waste generator for repackaging or shipped to interim storage in the burial ground for future processing in the TRU Waste Facility (TWF). WIPP-intended drums will be labeled and bar coded in compliance with WIPP-WAC prior to shipment. These certified drums are in interim storage awaiting future shipment to WIPP.

Construction of the second phase of the WCF was completed in 1988. This phase of the WCF includes facilities to bar code and prepare the drums for shipment, and load the drums into the TRU Package Transporter-II (TRUPACT) for shipment to WIPP. Equipment to bar code, label, and band the drums into a seven-pack array will be procured prior to startup of the facility.

All TRU wastes are currently being stored on concrete pads in E. Area pending startup of WIPP in Carlsbad, NM. The higher activity $(238 \mathrm{Pu})$ fraction of SRS waste is not shippable without processing to decompose or decontaminate the waste form. This is particularly true of the combustible waste, which has high-hydrogen gas generation rates. However, as much as 70 percent of SRS TRU waste falls outside this category and is shippable with just repackaging and/or certification per the current WIPP-WAC.

TRU waste shipped to WIPP will be transported in a new transport container, the TRUPACT-II. The TRUPACT-II, designed for WIPP by Nuclear Packaging, Inc, has been granted a Certificate of Compliance $(C$ of $C$ ) from the Nuclear Regulatory Commission to transport specific payloads which have been packaged to detailed requirements as outlined in the $\mathrm{C}$ of $\mathrm{C}$ and supporting documentation. Prior to shipping waste to WIPP, SRS must revise the existing TRU waste certification program to comply with the TRUPACT C of C requirements. Revision of the program, once initiated, will require 18 months to 2 years as a minimum. SRS waste that cannot be packaged to meet TRUPACT-II thermal power limits will be placed into interim storage to await processing in a future transuranic waste treatment facility to be defined.

\section{TRU Waste Facility}

The TRU Waste Facility (TWF) will be designed to retrieve and process TRU waste and prepare it for certification and permanent disposal at WIPP or disposal as low-level waste.

As retrieved waste is needed at the process building, the four-foot soil cover over the stored TRU waste pads will be removed with earth moving equipment to within approximately six inches of the waste containers. The remaining soil will be removed with a remotely operated, HEPA-filtered soil vacuum. Due to the generation of potentially explosive gas mixtures by radiolysis within waste drums, the drums will be removed from storage using a lifting canister and placed in an explosion resistant cask for transportation to the TWVI. 
Large steel boxes and concrete culverts will be lifted from the pads and placed directly on a transport trailer for shipment to TWF.

Waste containers will be received into the TWF through an airlock into a high bay storage and opening area. The drum transportation cask will be placed directly into an explosion resistant cell, and the drums will be removed individually. The concrete culverts will also be opened in this cell. The technique for culvert opening uses a wedge-type opening device for breaking the grout seal. After the drums are removed from the shipping containers and concrete culverts, they will be vented to remove radiolytic gases and purged with inert gas. Each drum will be fitted with a carbon-composite filter vent before being introduced into the verification area. Steel boxes retrieved from the burial ground will be opened in a separate cell in the high bay storage and opening area, and plywood boxes will be removed and processed individually through the facility.

The facility will provide two separate and independent process paths. One process path will be primarily for the handling of drums and the other for the handling of plywood boxes. Other nonstandard containers (polyethylene boxes, concrete casks, etc.) will be handled according to their size and manner in which they are stored.

Drums will be assayed to determine the curie content for inventory control and record purposes. All containers will then be $x$-rayed to identify any object or liquids which must be removed to meet the WIPP WAC. Drums containing $<100 \mathrm{nCi} / \mathrm{g}$ of transuranics and no free liquids will be removed from the building and handled as low-level waste. All other drums will pass through an airlock into the Waste Prep Cell. In a separate process path, plywood boxes will be assayed to indicate the level of contamination and also moved into the Waste Prep Cell.

The Waste Preparation Cell will be "..te point where the box processing and drum processing lines converge. Operations conducted within the cell include opening of waste containers; sorting to remove noncertifiable items; venting internal containers; size reduction through shredding, sawing, or plasma arc cutting; solidification of liquids; fixation of respirable fines; and repackaging. Remote operations will be conducted with a computer-controlled telerobot manipulator capable of handling a variety of hand tools and plasma arc cutting torch. In addition, five sets of master/slave manipulators and a solidification glovebox will be used for a number of the processing steps listed above.

After processing the waste to meet WIPP-WAC and transportation requirements, the waste will be removed from the Waste Preparation Cell through a 55-gallon drum bagless transfer system or Standard Waste Box (SWB) bagout portal. The SWB can hold up to four 55gallon drums or bulky equipment such as glove box components. Final product containers will be monitored for fissile content and transported to the WCF for final certification and preparation for shipment.

\subsection{Hazardous Waste Management}

Waste is considered hazardous if it exhibits any of the characteristics of ignitability, corrosion, reactivity, or the Toxicity Characteristic Leaching Procedure (TCLP) as defined by RCRA, or if it is a listed hazardous waste in RCRA. Typical hazardous wastes at SRS are lead, mercury, cadmium, 1,1,1-trichloroethane, leaded oil, Freon ${ }^{\mathrm{TM}}$, benzene, and 


\section{BY PROGRAM}

paint solvents. Figure 3.10 shows the process flow diagram for managing nonradioactive nonhazardous waste.

Nonradioactive hazardous waste is stored onsite in three SCDHEC-permitted storage buildings (Buildings 710-U, 709-G, and 709-4G, and area adjacent to Buildings 709-G and 4G). The RCRA Part B Permit was received for these buildings on September 30, 1987. The buildings are constructed with sloped floors, dikes, and sumps to provide adequate containment in the event of a spill. Effective separation of incompatible waste is provided. The waste storage containers are primarily 5-gallon and 55-gallon Department of Transportation (DOT) approved containers. Many of these containers are inside 83-gallon overpacks which serve as a secondary container for those contain rs of questionable integrity.

The site currently has a contract with an offsite vendor to ship some of the hazardous waste offsite for treatment and dispocal. This allows the site to maintain its current capabilities of storing hazardous waste without having to add more storage facilities.

\section{Future Facilities}

A Hazardous Waste/Mixed Waste Facility is currently being designed to treat and dispose of hazardous and mixed waste (Figure 3.11). The project will provide RCRA permitted treatment and disposal for solid hazardous and mixed waste that cannot be disposed of in existing or planned facilities. The facility will also eliminate the need to transport hazardous waste offsite. The project is divided into two phases: Phase I is the Treatment Building, and Phase II is the Disposal Vaults.

The Treatment Building will contain equipment and processes that will be able to treat hazardous and mixed waste streams so that the waste will be in a suitable form to be disposed in the vaults. Not all equipment and processes have as yet been identified. An effort is currently underway to identify current and future hazardous and mixed waste streams so that the proper equipment and processes can be developed. In general, the Treatment Building will treat hazardous and mixed waste that does not meet the Waste Acceptance Criteria of the CIF (see section 3.3.2.6.2 for a description of the CIF).

The waste treated by the CIF and the Treatment Building will be disposed of in disposal vaults that will be built as Phase II of the Hazardous Waste/Mixed Waste Facility. A minimum of two above-grade vaults will be built. Additional vaults may be added as separate projects in the future.

\subsection{Mixed Waste Management}

Hazardous waste as defined by SC Hazardous Waste Management Regulations, i.e., lead, cadmium, and mercury, that is also radioactively contaminated is designated mixed waste and is segregated for storage in SCDHEC-permitted facilities until a treatment and disposal facility can be constructed. The Hazardous Waste/Mixed Waste Disposal Facility and the CIF will be designed to eliminate the storage of newly generated and untreated hazardous and mixed wastes (see section 3.3.2.6.2 for a description of the CIF and section 3.3.2.6.4 for a description of the Hiazardous Waste/Mixed Waste Disposal Facility). Mixed waste is currently placed in interim storage at Building 643-29E in the E Area Solid Waste Disposal 
Facility, and Buildings 643-7G and 709-2G in the Central Shops area. Waste is contained in drums, concrete culverts, and large metal boxes. These are SCDHEC-permitted facilities and will be in use until the completion of the Hazardous Waste/Mixed Disposal Facility and the CIF. Figure 3.12 shows the process flow diagram for managing mixed waste.

\section{Future Facilities}

Besides the CIF and Hazardous Waste/Mixed Waste Disposal Facility, another storage building is being constructed to provide more storage capacity of mixed waste onsite. This building will be labelled 643-43E and will be located next to the current mixed waste storage building 643-29E (in the SWDF near the TRU Storage Pads). The building will be a low hazardous facility. An application for the RCRA Permit Part B is currently being completed. The building will operate under an interim status until the Part B is approved. The building is subject to design criteria in the DOE Order 6430.1A, Division 13. The building is scheduled to begin operation in August 1991.

\subsection{Sanitary Waste Management}

The SRS operates its own sanitary waste landfill. The landfill is divided into three sections, the original landfill, the southern expansion and the northern expansion. The original landfill has reached capacity. The southern expansion is currently being used and, at current waste generation rates and disposal methods, is expected to be full by 1992 . At that time, the northern expansion will be utilized. The section is expected to provide capacity until 1997 if current generation rates continue. The northern expansion will cease operation when the New Sanitary Landfill is available.

New methods in waste handling and disposal are being implemented to extend the life of the northern expansion. The technology that will be employed is the pit method. This method has been developed, tested, implemented, and proved at landfills throughout the country in a variety of topographies and geologic formations. A weigh scale system will be used to determine how much waste is being disposed in the landfill.

The existing landfill site has documented groundwater contamination and is currently operating under the permit conditions of SCDHEC permit number DWP-087A which was submitted to SCDHEC in July 1989. Concentrations of at least one of the following constituents, tritium, gross alpha, and trichloroethylene in excess of the primary drinking water standard were observed in at least one well monitoring the landfill in the first half of 1989. All three of these constituents have been detected in elevated levels at the same wells in more than one quarter. The SCDHEC has not reissued the referenced permit but continues to allow SRS to operate under the conditions of the expired permit. The existing monitoring well network is to be evaluated to determine its acceptability to current state and federal regulatory requirements. Should assessment of the existing monitoring well network prove inadequate, the monitoring well network shall be modified to meet applicable federal and state regulatory requirements. 


\section{Future Facilities}

The New Sanitary Landfill will provide a 20-year capacity for sanitary waste disposal in accordance with rigorous Federal and SCDHEC requirements. The landfill will incorporate a synthetic liner and leachate collection system to satisfy the new requirements of RCRA Part D and the SC Solid Waste Management Act of 1991. A performance assessment system will monitor for leaks in the liner. The New Sanitary Landfill will be available in 1996.

\subsubsection{Defense Waste Processing Facility (DWPF)}

\subsection{Vitrification}

The objectives of the DWPF S-Area Vitrification process is to take the liquid high-level radioactive waste currently stored at the SRS and permanently immobilize it as a glass solid. The vitrification operations include chemically treating two unique waste streams, mixing them with a ground borosilicate glass and then heating the mixture in an electric melter to 1130 degrees centigrade. The molten mixture is then poured into ten-feet-tall, two feet in diameter stainless-steel canisters and allowed to harden. The outer surface of the canisters is then decontaminated to DOT standards, welded closed and temporarily stored onsite for eventual transport to and disposal in a permanent federal geological repository.

\subsection{Saltstone}

\section{Saltstone--Z Area}

The DWPF Z-Area Saltstone processes low-level radioactive liquid waste salt solution from the In-Tank Precipitation Facility and the Effluent Treatment Facility. The solution is mixed with a blend of cement, flyash and blast furnace slag to form a grout. The grout is pumped in disposal vaults where it hardens into a solid nonhazardous waste form for permanent disposal.

\section{Future Facilities}

The DWPF Y-Area Saltstone will provide processing and disposal facilities for hazardous and low-level mixed waste salt solutions. This facility will process the current inventory and future production of $M$ Area mixed waste salt solution and will support the Consolidated Incineration Facility by treating and disposing of scrubber blowdown. Saltstone Y-Area will have a number of interfaces with Saltstone Z-Area Facility. Figure 3.13 shows the saltstone disposal plan. The interfaces include the bulk dry materials unloading and storage facilities; fire water; domestic and process water; septic system; and instrument and breathing air system backup. The Saltstone Y Area will also be operated with Z-Area personnel. 


\subsubsection{Savannah River Laboratory}

\subsection{Low-Level Waste (LLW)}

\section{Treatment}

\section{- Support for Effluent Treatment Facilities}

Treatment of low-level radioactive effluents from processes across the site includes testing in support of fouling problems with filters, ion exchange columns and reverse osmosis, control of biciogical growth in operations and influent streams, and sampling programs associated with these programs. It also includes testing efficiencies and operation of suggested treatment alternatives to handle liquid wastes.

Continuity of Operations

\section{- Low-Level Waste Storage/Disposal Burial Ground Operation}

This activity provides for development of packaging requirements and demonstration studies for the new SRS LLW Disposal Facility.

\section{- Replacement 735-A Low-Activity Drain System}

This project will provide a piping system to move low-activity waste from Building 735-A, a laboratory facility, to Building 776-A, the waste storage and handling facility.

Waste is currently stored in above-ground and below-ground holding tanks and then loaded into a tanker trailer for shipment to F-Area. The RCRA land ban regulations will require that a method be developed to remove hazardous constituents before shipment. The existing system does not have this capability. Piping the waste from 735-A to the proposed Effluent T'reatment Facility (776-A) would provide a method of removing hazardous material.

\section{- Technical Support for SRS Waste Management Activities}

Technical (engineering) support in the areas of material consultation, system remote inspection, special sensing instrumentation, and robotic equipment development are planned.

\section{Disposal}

\section{- Z-Areá Saltstone}

Solidification of waste converted to saltstone in Z Area includes formulation changes, leach tests, modeling for different waste compositions, consultation to technical groups, and support of hot startup. Coordinaitt: 


\subsection{PRIMARY SITE-SPECIFIC OBJECTIVES BY PROGRAM}

assessment for Z-Area per DOE Order 5820-2A will include performance modeling and coordinating writing of the assessment .

\section{Program Support}

\section{- Decontamination Support}

This task is to provide support of decontamination for general site applications. It includes integration of robotics with decontamination techniques, electropolishing, foam applications, and setting up a decontamination arsenal of equipment.

\subsection{High-Level Waste (HLW)}

Treatment

\section{- ITP/ESP (DWPF Feed Prep/Operation) Support}

Support for startup of the in-tank precipitation/extended sludge processing includes assistance with technical documentation, chemistry studies of the process, testing to provide cold feeds reliability, determining cleaning requirements for equipment, issues of benzene generation, and reduction of emissions to the environment.

- Waste Qualification

The work is funded by the lead site and responds to RW-0260, Waste Acceptance Preliminary Specifications for the DWPF HLW Form. It provides the basis or acceptance of the DWPF product and information needed to demonstrate compliance with RCRA requirements. This activity is essential for DWPF startup; it requires SRL. High Level Cells and Analytical Development Section facilities to produce and analyze glass from radioactive feeds and pilotscale process facilities to develop and demonstrate process control techniques. Specific near-term goals are revision of the Waste Acceptance Preliminary Specification (WAPS), revision and gaining approval of the DWPF Waste Form Compliance Plan (WCP), preparation of the DWPF Waste Form Qualification Report (WQR), revision of the WQR as required by EM's Technical Review Group, support of the Waste Acceptance portions of the DWPF Start-up Test Program, completion and delivery of the DWPF Product Composition Control System, development of radio-isotopic analytical methods required for reporting of glass composition to repositories, demonstration of approach to compliance by analyzing radio-isotope content of process stream in small-scale process in High Level Cells, and implementation and improvements of QA programs for DWPF product qualification and production.

\section{- Defense Waste Processing Facility}

The technology required to vitrify SRS HLW has bocn defined and providues the ability to: 1) comply with Federal Facility Compliance Agreement which 


\subsection{PRIMARY SITE-SPECIFIC OBJECTIVES BY PROGRAM}

requires start-up of DWPF by December 1993, 2) comply with RW-0260, Waste Acceptance Preliminary Specification for the DWPF HLW Form, and 3) support continued operation of SRS Reactors, Separations and other Waste Management facilities. It provides the technology to analyze DWPF process streams to control the process, as well as the analytical capability for research into process problems and improvement. Technical support for DWPF includes:

- Identifying and solving process and operating problems prior to DWPF operation.

- Developing DWPF process and equipment characterization plans.

- Developing and providing specialized equipment to support DWPF start-up and operation.

- Testing long-term material corrosion in a process environment.

- Assisting in solving processing problems encountered during DWPF Startup.

- Developing and demonstrating process measurement and analytical methods. This activity is essential to DWPF start-up.

Three pilot plant (large-scale) facilities ranging in scale from full to $1 / 9$ th, and Analytical Laboratory equipped to perform all DWPF-related analyses, experimental laboratory facilities, and SRL High Level Cells and Analytical Development Section facilities are available.

In FY 1992, direct support of Chemical Runs and Qualification Runs begins with technical oversight and data analysis by SRL experts. Pilot-scale work continues completing hydrolysis optimization, piloting, Purex feed, and testing actual cold feed precipitate prior to DWPF runs. Analysis of actual DWPF chemical run samples will be initiated. Analytical method development activity will decrease; troubleshooting will increase.

Funding requirements increase in FY 1992 (continuing into FY 1993) to provide a replacement for the aging large-scale melter at $\mathrm{TNX}$, required to avoid costly troubleshooting in a radioactive environment. Funding in FY 1992 provides additional analytical laboratory space and instrumentation at TNX to meet requirements to analyze DWPF Cold Chemical Run samples and organic process contaminants.

- Performance Improvements in HLW Processing and Waste Handling

This activity is directed at improving operations of the HLW tank farm by providing technology to enhance current operations.

\section{- Improved Automation of DWPF}

The present DWPF distributed control system monitors over 6,000 process variables. Identification of potential process operating problems and/or instrument failures is performed by a fixed number of operators and engineers. 
Improvements in the automation capabilities of DWPF will provide significant benefits in process attainment as well as safety and environmental protection. Process interlock troubleshooting, instrument fallure analysis, multiple alarm analysis, and online procedures system will be developed.

\section{Storage}

\section{- HLW Storage/Tank. Farm Support}

This activity supports the study of the chemistry of HLW to ensure that corrosion data, corrosion mechanisms, and waste chemistry data bases are maintained for continued safe storage.

\section{- Pressurization of 904-A Trench}

Radioactive wastes from Building 773-A are transported through a pipe system to Building 776-A, where they are stored in temporary holding tanks. The transfer piping is contained in an underground concrete trench (904-A) that has been in use since the early 1950s. The trench consists of a concrete trough with precast slabs that are sealed to the top of the trough and covered with asphalt for waterproofing.

This activity will provide a method of stopping rainwater in-leakage that now enters the trench through the degraded waterproofing seals. This rainwater must be handled and disposed of as low-activity waste.

\section{Continuity of Operations}

\section{- HLW Process Development Analytical Support}

This activity provides analytical support for HLW activities at SRS. This includes support for tank chemistry studies and operation of the High Level Caves for waste handling and small-scale testing.

\section{- Replacement/Upgrade of 776.A Waste Handling Facility}

This project provides an effluent waste treatment facility for the SRL Technical Area.

\section{- Waste Management Operations}

This activity supports collection, packaging, storage, and transport of radioactive, hazardous, and mixed waste generated as a result of ongoing operations of the SRL. 
- Preparation of Part B Permit

The SRL Mixed Waste Tanks are currently under RCRA interim status with a Part A permit. SCDHEC could require a Part B permit application to be subiritted at any time. From the date SCDHEC requests the Part B permit application, SRS would have only six months to prepare the application. The effort and time required to prepare a Part B permit application is extensive and the approval process is lengthy. Time estimated to complete preparation of a Part B permit application for the SRL Mixed Waste Tanks is at least eight months. Failure to submit a complete and satisfactory permit application could result in permit denial and loss of the existing interim status permit. Consequently, research programs that generate hazardous and mixed waste would have to be discontinued. To ensure continued operation of the facility, the process must begin as soon as possible.

\subsection{Low-Level Mixed Waste}

\section{Continuity of Operations}

\section{- Production Monitoring Support}

SRL Environmental Technology Section applies special ultra low-level detection and measurement technology to drums of mixed wastes requiring lower limits of radioactivity content than can routinely be measured by operations technology. This activity is necessary in screening wastes for of fsite disposal, and minimizes the generation of CERCLA sites.

Disposal

- Mercury Disposal

The DWPF will process 5 to 10 tons of mercury per year. Less than half of this can be recycled back to the separations process. Although the mercury is cleaned up in the DWPF, it remains contaminated with trace amounts of radioactivity. A marketable or environmentally sound disposal form of the mercury must be found. The mercury can either be decontaminated to the point where it can be used commercially or it must be converted chemically to a form that passes the EPA toxicity tests.

\subsection{Sanitary Waste}

\section{Disposal}

\section{- Sanitary Sewer Upgrade, T Area}

This activity will upgrade the lines and lift stations of the existing TNX sanitary sewer. Two new lift stations, associated pumps, control system, and piping are required. Septic tanks must be replaced with new manholes. Sections of the antiquated piping must be replaced. 


\subsection{Hazardous Waste}

\section{Continuity of Operations}

\section{- Containment Characterization and Evaluation of Tim's Branch}

Existing data indicated that substantial quantities of heavy metals have been deposited in the sediments and floodplains of Tim's Branch. The major objectives of this program are to: 1) determine the extent and magnitude of heavy metal contamination of Tim's Brarch stream and floodplain sediments; 2) determine the toxicity of the contaminated sediments to aquatic biota; 3) determine the exchange rates of selected heavy metals between the sediment/water interface; 4) examine the role of aquatic macrophytes in metal mobilization from Tim's Branch sediments.

\subsection{Transuranic Waste}

\section{Continuity of Operations}

\section{- TRU Waste Processing Technology}

This activity provides plant technical support for TRU waste storage in the Solid Waste Disposal Facility, E Area. Technisal support for design of the TRU Waste Facility (TWF) is also provided.

\subsection{Other}

Treatment

\section{- Consolidated Incineration Support}

This activity provides technical support for final design and startup of the Consolidated Incineration Facility (CIF). This includes evaluation of the CIF offgas system using the Offgas Components Test Facility (OCTF).

- Effuent Treatment Expansion, T Area

This project will provide additional tanks, pumps, piping, filters, clarifiers, and other wastewater treatment equipment to increase the capacity of the existing
TNX Effluent Treatment Plant. 
- Replacement of Section "E" Process HVAC, 773-A

This activity is for replacement of process supply units EP \#5901 and EP \#20922 in Section "E" (Shielded Cells) of Building 773-A. This area of SRL supports the DWPF program.

EP \#5901 is installed in the original portion of the High Level Caves. It supplies conditioned air to the " $\mathrm{A}$ " cell block operating and maintenance areas to maintain differential pressures and air flow patterns required to prevent radionuclides from exiting the shield cells. EP \#20922 is installed as an addition to the High Level Caves. It supplies conditioned air to the cell mockshop and maintains air flow patterns to prevent the escape of radionuclides to the environment.

The existing units have deteriorated, provide marginal performance and require frequent repairs.

Dispesal

- Process Sewer Upgrade

This activity will replace deteriorating sections of the old process sewer system at T-Area, which has been in place for more than 30 years.

Continuity of Operations.

- Safety and Continuity

This activity provides safety documentation for new and ongoing waste management operations (SAR's, ICO's, OSR's HAD's, etc.)

- Process Sewer Upgrade

This activity will install piping, tanks, and a lift station with associated pumos and control system to allow collection of laboratory effluents prior to discharge to the TNX Effluent Treatment Plant. This will allow sampling and analysis of the effluent to determine whether or not additional waste treatment (such as carbon adsorption) is required prior to discharge to the NPDES outfall.

\section{Storage}

- Tank Farms Remote Equipment

This activity provides remote equipment to improve tank farm operation and reduce personnel exposure. 


\section{- Ro Nacement Shielded Storage Exhaust System}

This activity replaces the shielded storage and manipulator decontamination facility exhaust system located in the Shielded Cells Facility in Building 773-A. The work includes replacing the existing equipment (fans and HEPA filter housing).

The existing HEPA filter housings do not have secondary containment and in the event of a failure, radionuclides will be released directly to the environment (exceeding NESHAP regulations).

\subsection{Technology Development}

\subsubsection{Introduction}

The Office of Technology Development (OTD) was formulated to support the efforts and ultimately satisfy the needs of its customers, DOE installations, the Office of Environmental Restoration, the Office of Waste Operations and Defense Programs. Within the OTD the Research and Development (R \& D) Program first provides the technology base necessary to determine the technical, economic and regulatory justification to transfer technologies to other divisions of OTL (Demonstration, Test and Evaluation, DT \& E). Innovative Technology and Applied Technology task areas identify and evaluate to provi the readiness of new technologies prior to transfer to DT \& E and other federal and private agencies or companies.

\subsubsection{Description of Activities}

\subsubsection{Waste Retrieval and Waste Processing}

Hazardous and Mixed Waste Treatment Technology Development:

This activity provides development of treatment technologies for hazardous and mixed waste streams generated at SRS. These technologies, when applied to wastes, will reduce the risk of degrading the environment, unnecessarily exposing workers and personnel and violation of state and federal regulations concerning environmenta' compliance. Activities performed under this task will also support the Underground Storage Tank Integrated Demonstration, Buried Waste Program and RCRA Component Destruction Integrated Program.

\section{SRL Electrolytic Oxidation of Hazardous and Mixed Waste}

This task will investigate the treatment technology of organic wastes by electrolytic oxidation. By oxidizing organic materials electrolytically, hazardous and mixed wastes can be rendered innocuous by converting them to such compounds as carbon dioxide and water. Development of this technology will reduce the volume of hazardous and mixed wastes in need of disposal, thereby reducing the risks associated with handling, shipping storage, and disposal. Activities performed under this task also support the Underground 


\subsection{PRIMARY SITE-SPECIFIC OBJECTIVES BY PROGRAM}

Storage Tank Integrated Demonstration, Buried Waste program and RCRA Compontent Destruction Integrated program.

\section{SRL TRU Waste Treatment}

This task will provide development of waste processing technology for the TRU Waste Facility (TWF) to ensure uncertifiable waste meets both shipment and disposal requirements for the WIPP. Activities performed under this task also support the Underground Storage Tank Integrated Demonstration, and the Buried Waste program.

\section{Aqueous Detritiation}

The principle task objective is to define a technical engineering approach for removal of tritium in tritiated light water from environmental sources to greatly reduce or eliminate offsite aqueous tritium releases. The technical lead approach will examine the use of solid phase precious metal supported catalysts in a liquid phase catalytic exchange process for tritium reduction.

\subsubsection{Integrated Demonstrations (ID)}

An integrated demonstration is a concept where timely and efiective applications of new and enhanced technologies are used to meet environmental restoration needs. An integrated approach best utilizes funding and talent by minimizing duplication of error and ensuring rapid evaluation of new technologies. Systems of technologies are evaluated with respect to performance, safety, and cost effectiveness through collaborative partnerships with DOE laboratories, universities, federal agencies, private industries, and the developers of each technology.

\section{Trichloroeth $/$ lene (TCE) Biodegradation Demonstration}

This is part of the ID, with a goal to develop and implement a system for demonstrating and evaluating the potential of in situ bioreclamation of cleanup of shallow subsurface contamination and bioreactor bioreclamation for cleanup of deep subsurface contamination from disposal of chlorinated hydrocarbons in unlined waste disposal facilities. This project is composed of two tasks. The first task will demonstrate the utility of using vegetation to enhance a microbial community in surface soils capable of rapid degradation of TCE and tetrachloroethylene (PCE). The second task will demonstrate a large-scale, continuous flow fermenter (bioreactor) for the treatment of TCE and PCE.

\section{Biodegradation for Cleanup of Organic in Soils and at Nonarid Sites}

This portion of the ID involves indigenous microorganisms which will te stimulated to degrade TCE, PCE and their daughter products in situ by addition of nutrients to the contaminated zone and by surface treatment of contaminated offgas and water. Biodegradation is a highly attractive technology for remediation because contaminates are destroyed, not simply moved to another location or immobilized. 


\section{Directional Drilling and Characterization}

This task will evaluate three innovative directional drilling technologies for environmental characterization, monitoring, and restoration applications. The three technologies are: downhole hydraulic motor, ultra-short radius radials and cable installation. Each site where a directional drilling technology is demonstrated will be characterized before the site is used to demonstrate remediation technology.

\section{Offgas Treatment for Cleanup of Organics in Soils and at Nonarid Sites}

This activity will demonstrate and assess the efficiency of innovative destructive or hybrid offyas treatment systems. Potential systems for demonstration include catalytic, biologic, thermal and electrochemical treatments.

\subsubsection{Administrative Support and Planning}

\section{Robotics Buried Waste Support}

This task will support the robotiss technology development effort by providing site tours of the SRS TRU Waste Handling Demonstration Facility providing information on SRS experience, providing a design review of the Idaho TRU Waste Handling Facility, and participating in planning sessions and conferences for buried waste robotics.

\section{Support for the Development of Arid Site Demonstrations}

The objective of this task if to provide support to $\mathrm{RL}$ for the Integrated Demonstration for cleanup of soils and groundwate: arid sites.

\section{Robotics Support Staffi Planning and Analyses}

This task supports the Robotics Technology Development Program (RDTP) by participation on the RDTP team which includes providing site tours, remote systems demonstrations and robotic demonstrations for Research, Development, Demonstration, Technology, and Evaluation and DOE personnel; attending workshops and conferences and participating in RDTP meetings.

\section{Planning for Waste Management Integrated Demonstration}

The objective of this task is to assist in preliminary planning as directed by EM-55 in cooperation with the other operations offices and sites on proposed Integrated Demonstrations involving waste retrieval and processing and advanced processing technologies.

\section{Technical Program Officer/Technical Program Manager Support}

This task provides support in managing field activities, providing input to OTD's planning and implementation and identifying human resources for both technical and programinatic matters. Responsibilities include: operational oversight, task cost/schedule control issue 
resolution, status reporting, needs identification, internal and external demonstration, coordination with other sites, and external and internal communications.

\section{Analytical Laboratory Management - Methods Compendium Development}

This task will develop and provide the Laboratory Management Branch with data on the cost of performing radioactive and nonradioactive chemical and nuclear analyses in support of SR environmental restoration and waste management programs and in support of DOE Future Analytical Support Team-related activities by identifying analytical procedures used in support of the environmental and waste programs and by assisting in evaluating SR analytical methods and laboratory QA/QC programs.

\subsubsection{Education}

\section{Qutreach Program in Support of Educational Initiatives}

This activity will continue a program of outreach that provides encouragement, education opportunities and career counseling to economically or educationally disadvantaged or minority students, guiding them toward careers in environmental restoration and waste management.

\section{Pilot Center for Education, EM Research and Development and Qutreach}

This task will provide for a pilot center, formed by a consortium of major universities in South Carolina and WSRC, that will address the ER/WM issues through the education of the next generation of scientists, engineers, and technologists required to meet the state and nation's needs for sound technical solutions to ER/EM problems.

\section{Model Technology Integration Program}

This task provides support which facilitates the DOE's waste remediation technology by other government agencies, such as National Aeronautics and Space Administration, to encourage the use of industrial partners so that DOE can rapidly move forward in demonstrating applicable technologies in Phase Two of the Integrated Demonstration at SRS. 
WSRC-RP-91-596

SITE SPECIFIC PLAN

3.0 PRIMARY SITE-SPECIFIC OBJECTIVES

Effective 8/1/91

Page 41 of 55

BY PROGRAM

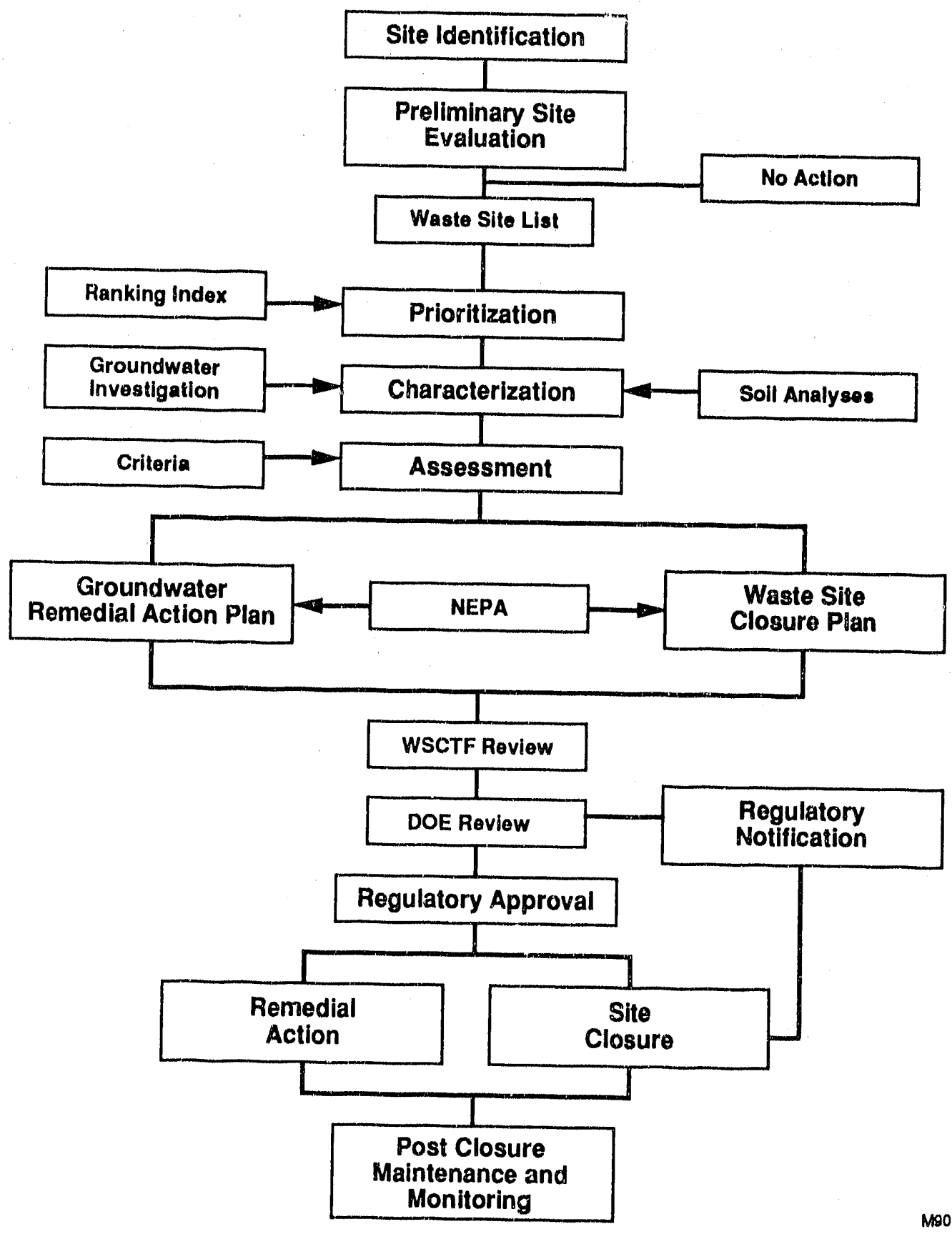

$M 906094$

Figure 3.1 Savannah River Site Waste Site Closure Pathway 


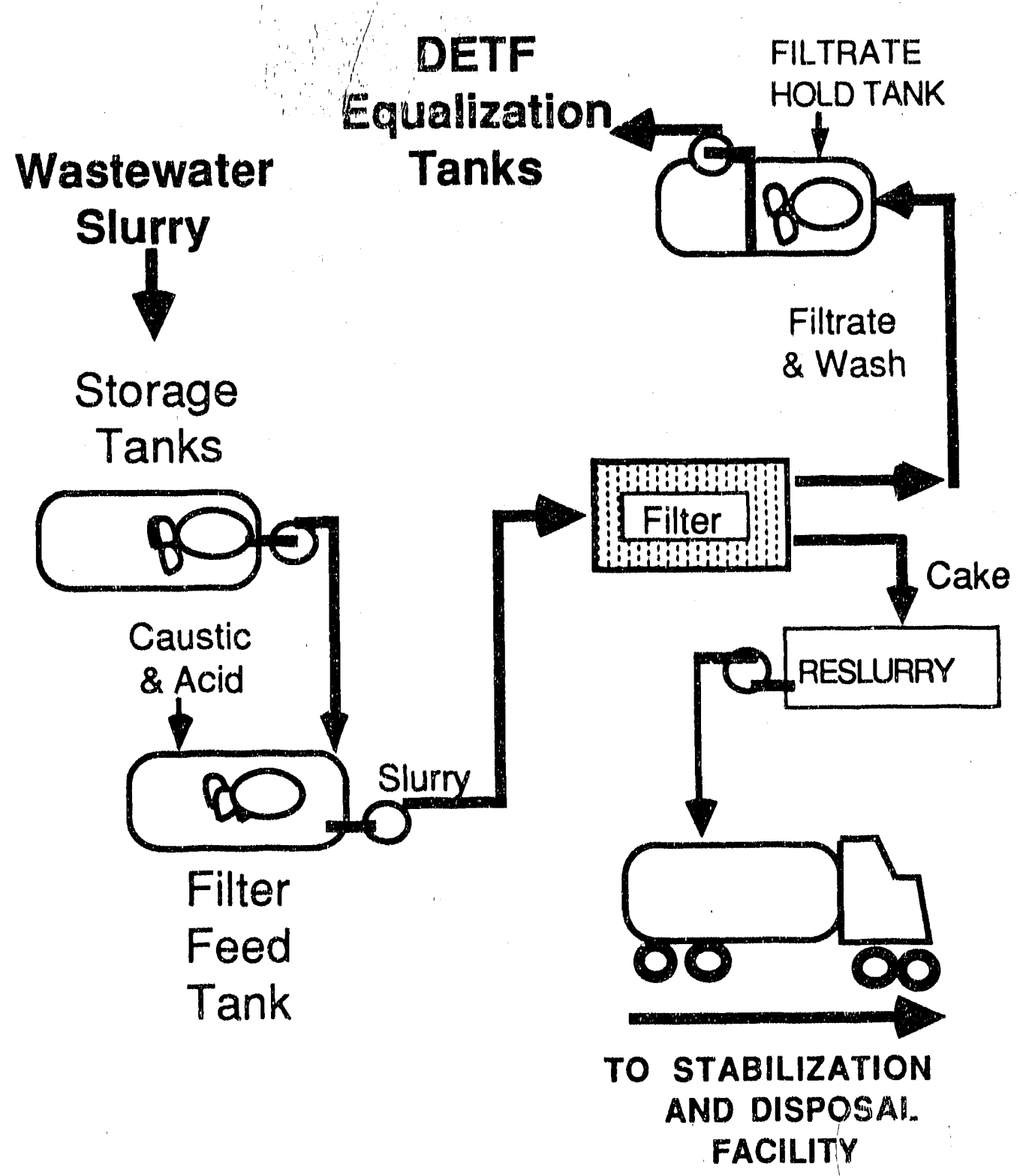

Figure 3.2 Conceptual Plan for Pretreatment Process 

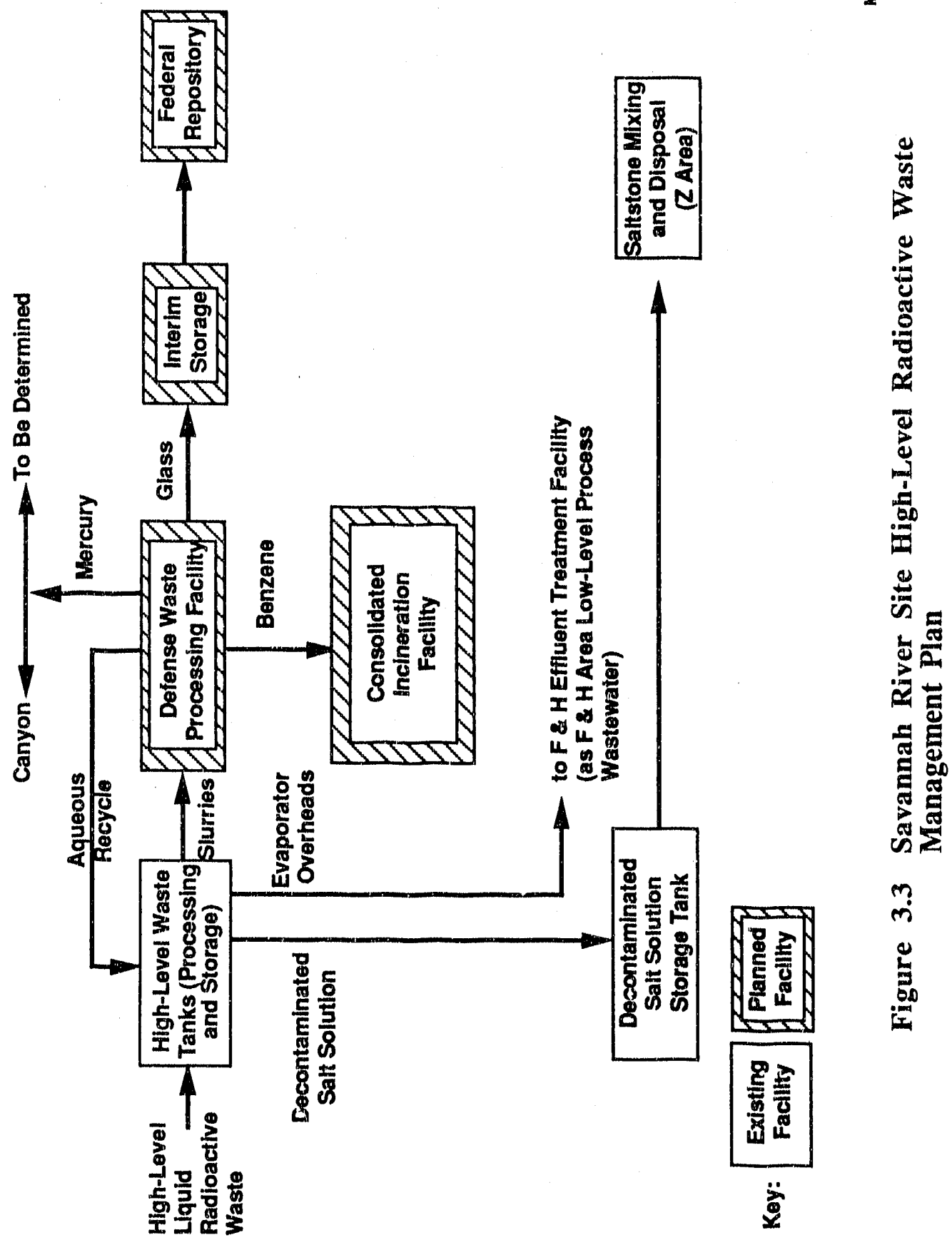
WSRC-RP-91-596

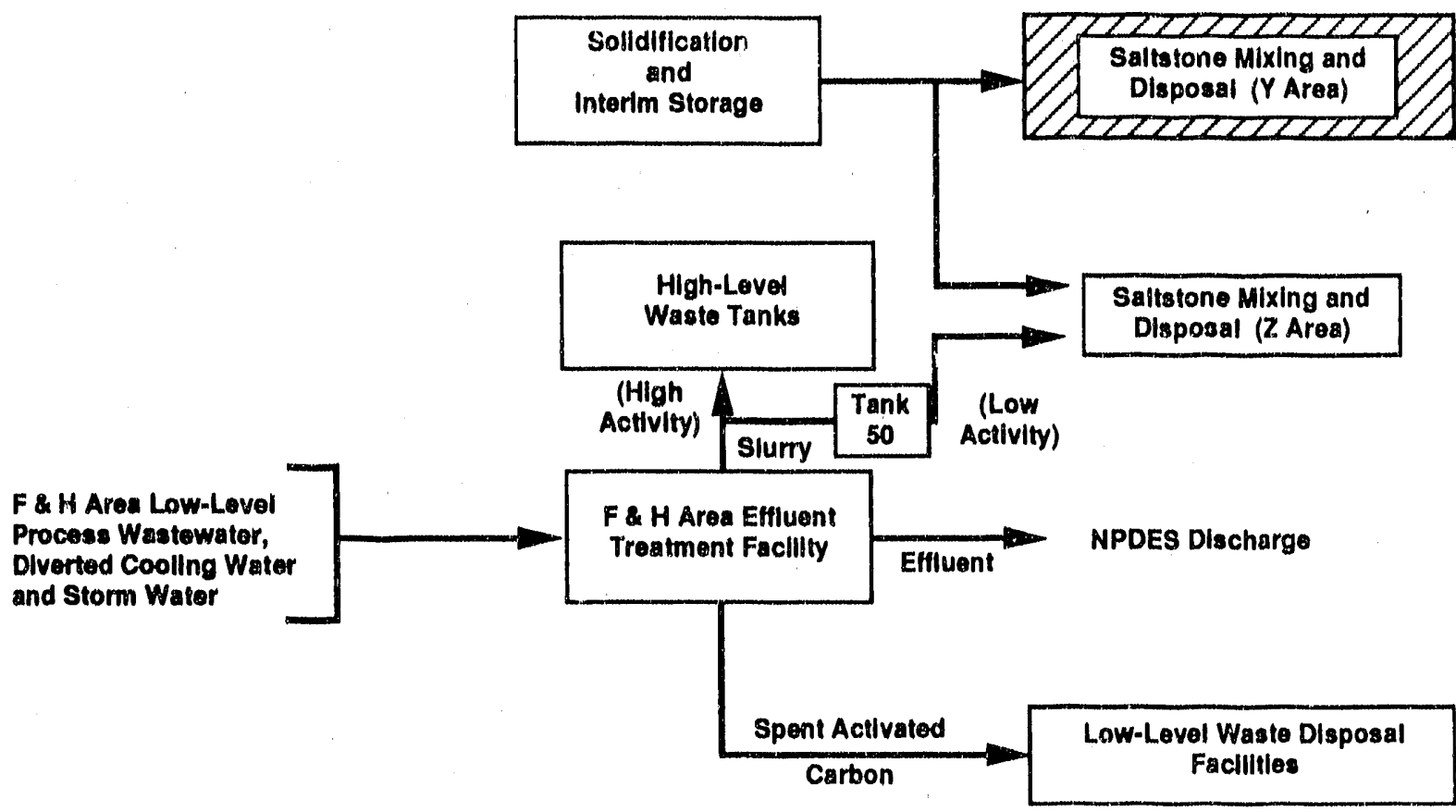

Key: $\begin{aligned} & \text { Exlsting } \\ & \text { Facility }\end{aligned}$

(Soo trillated waste water management plan.)

Figure 3.4 Savannah River Site F- and H-Area Effluent Treatment Facility Waste Management Plan 
WSRC-RP-91-596

SITE SPECIFIC PLAN

3.0 PRIMARY SITE-SPECIFIC OBJECTIVES

Effective 8/1/91

Page 45 of 55 BY PROGRAM

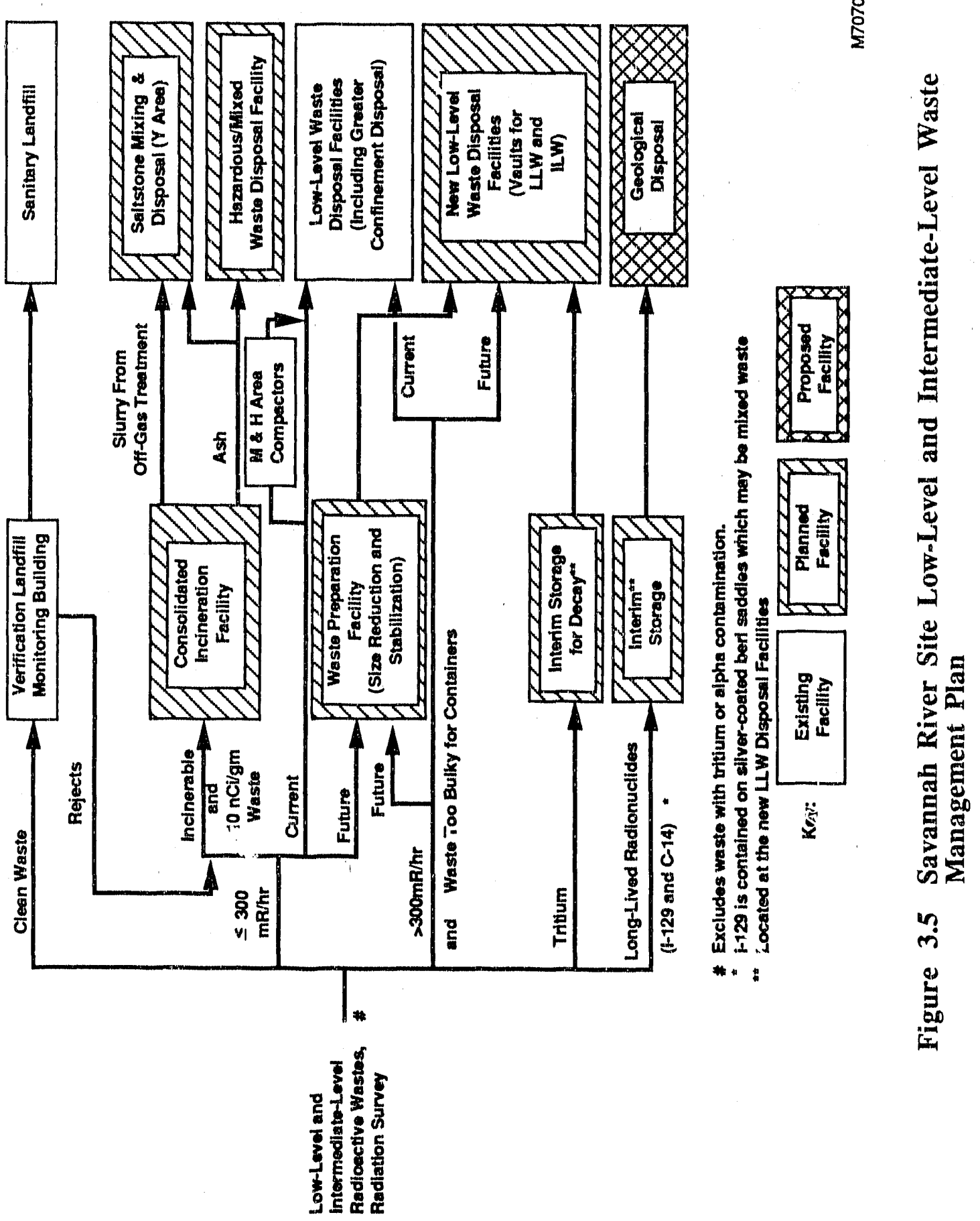



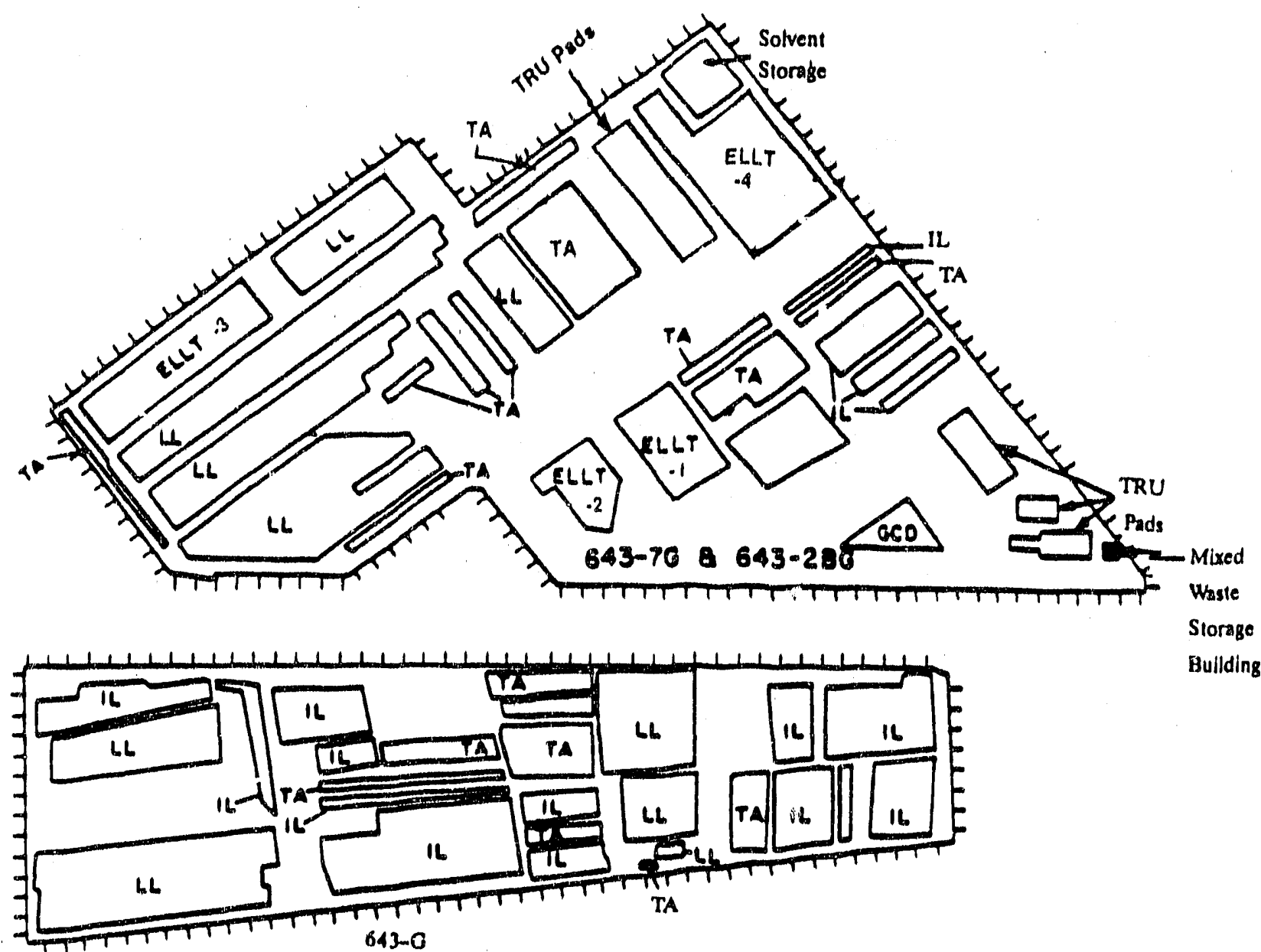

LL - Low BetamGamma Waste

IL - Intermediate Beta-Gamma Waste

TA - Trench Alpha Waste

GCD - Greater Confinement Disposal

ELLT - Engineered Low Level Trench

Figure 3.6 Solid Waste Disposal Facility, E Area 
WSRC-RP.91.596

SITE SPECIFIC PLAN

3.0 PRIMARY SITE-SPECIFIC OBJEC'TIVES

BY PROGRAM
Effective 8/1/91

Page 47 of 55

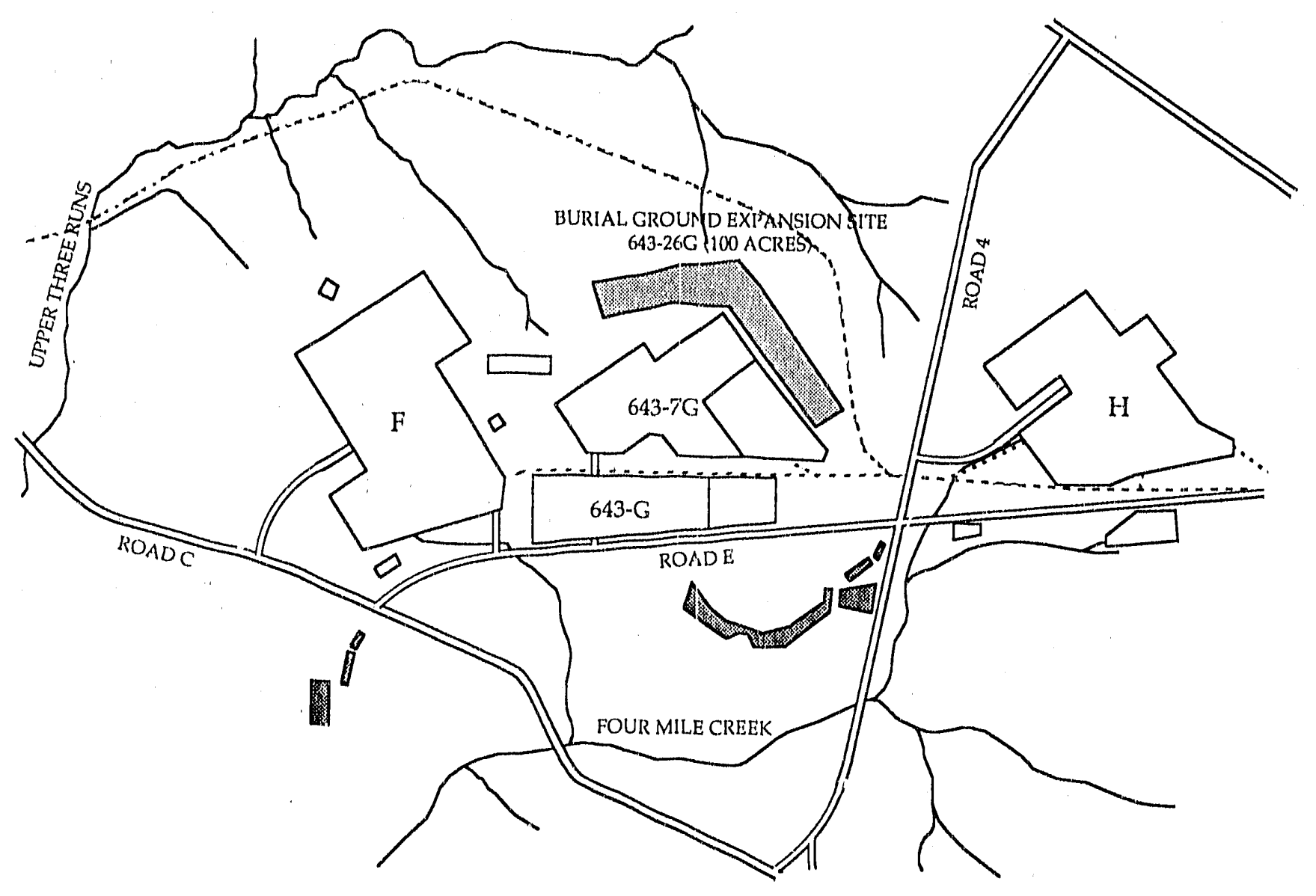

Figure 3.7 E-Area Vaults 


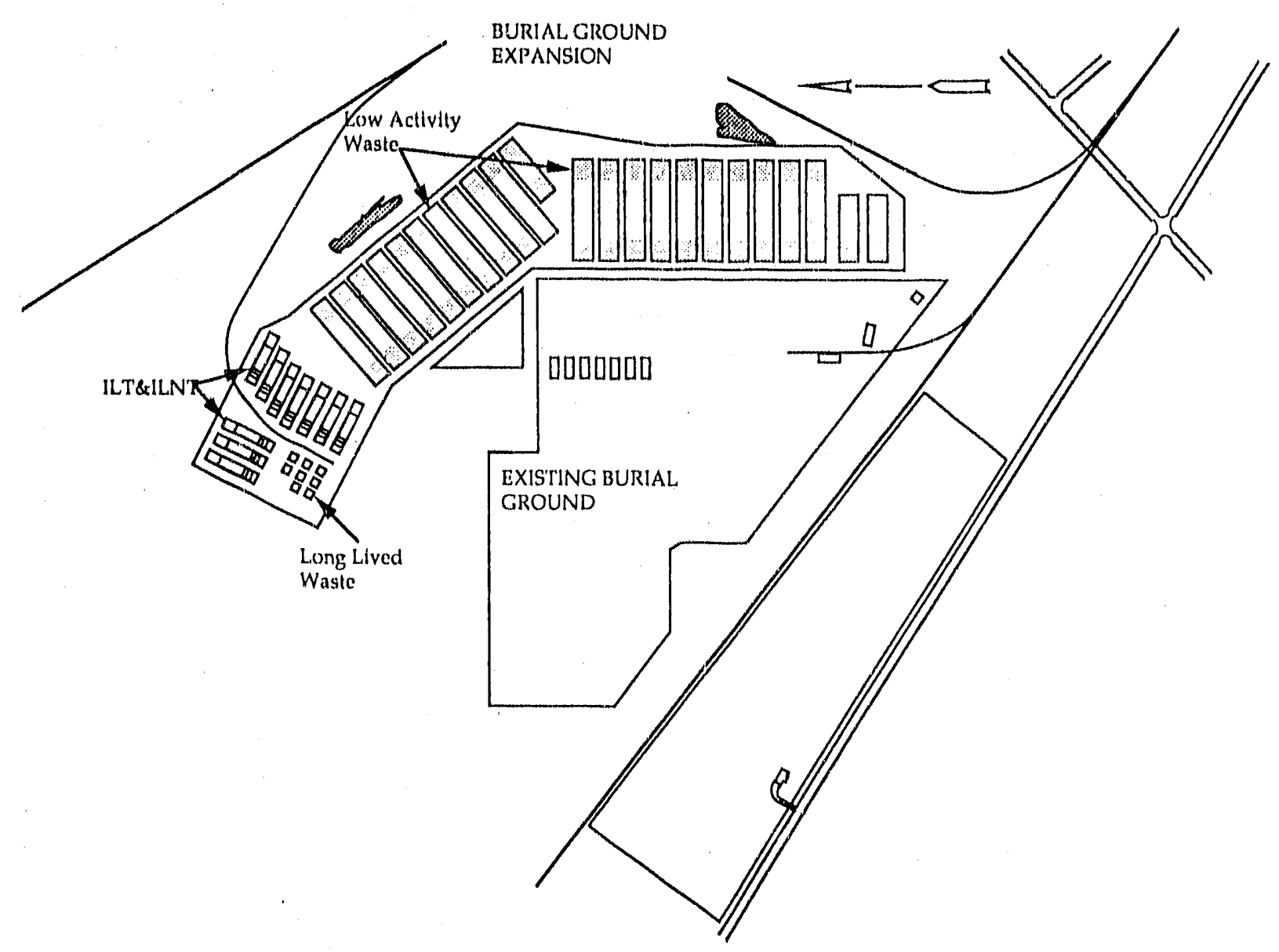

Figure 3.7 E-Area Vaults (Contd) 


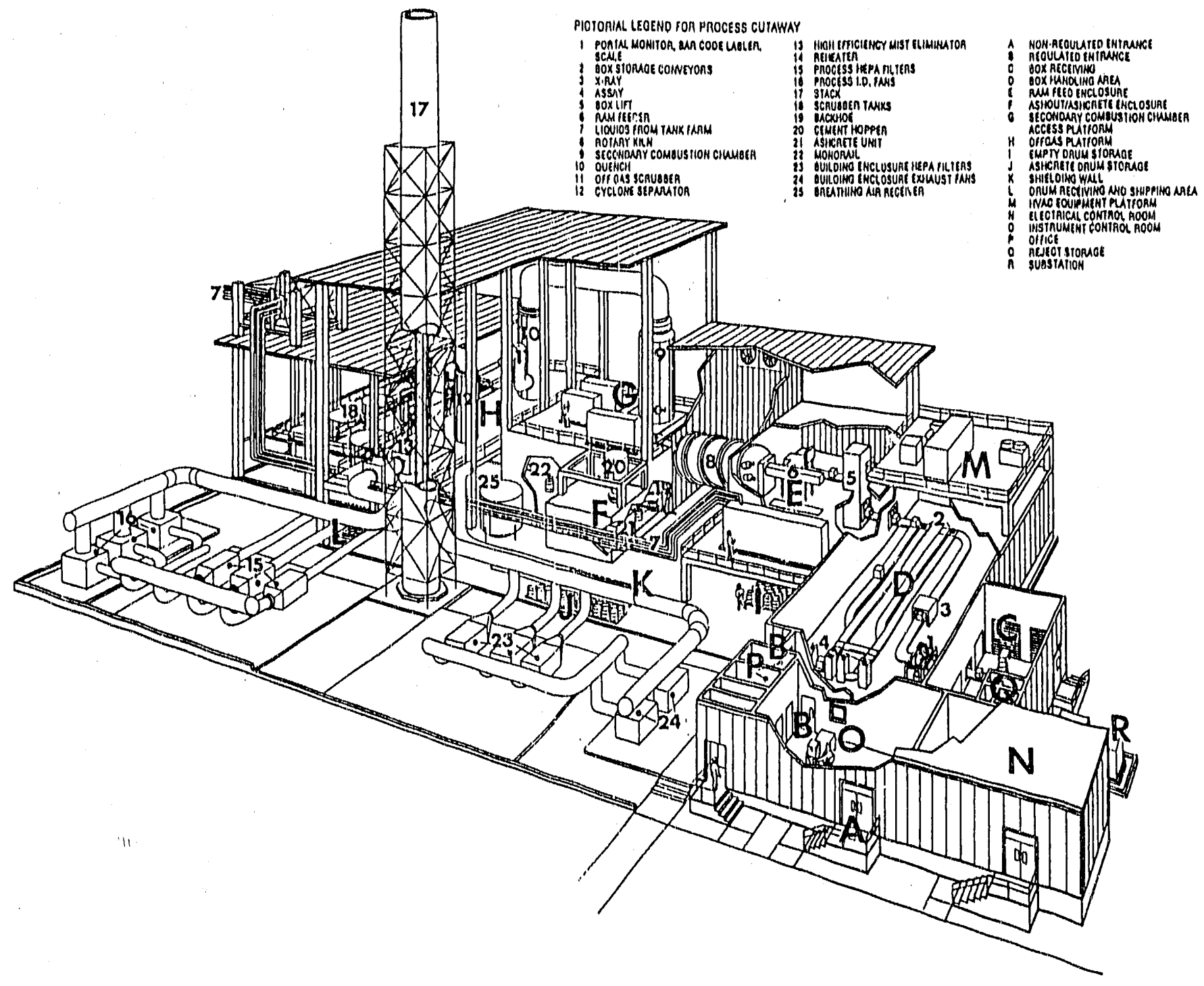

Figure 3.8 Consolidated Incineration Facility 


\section{BY PROGRAM}

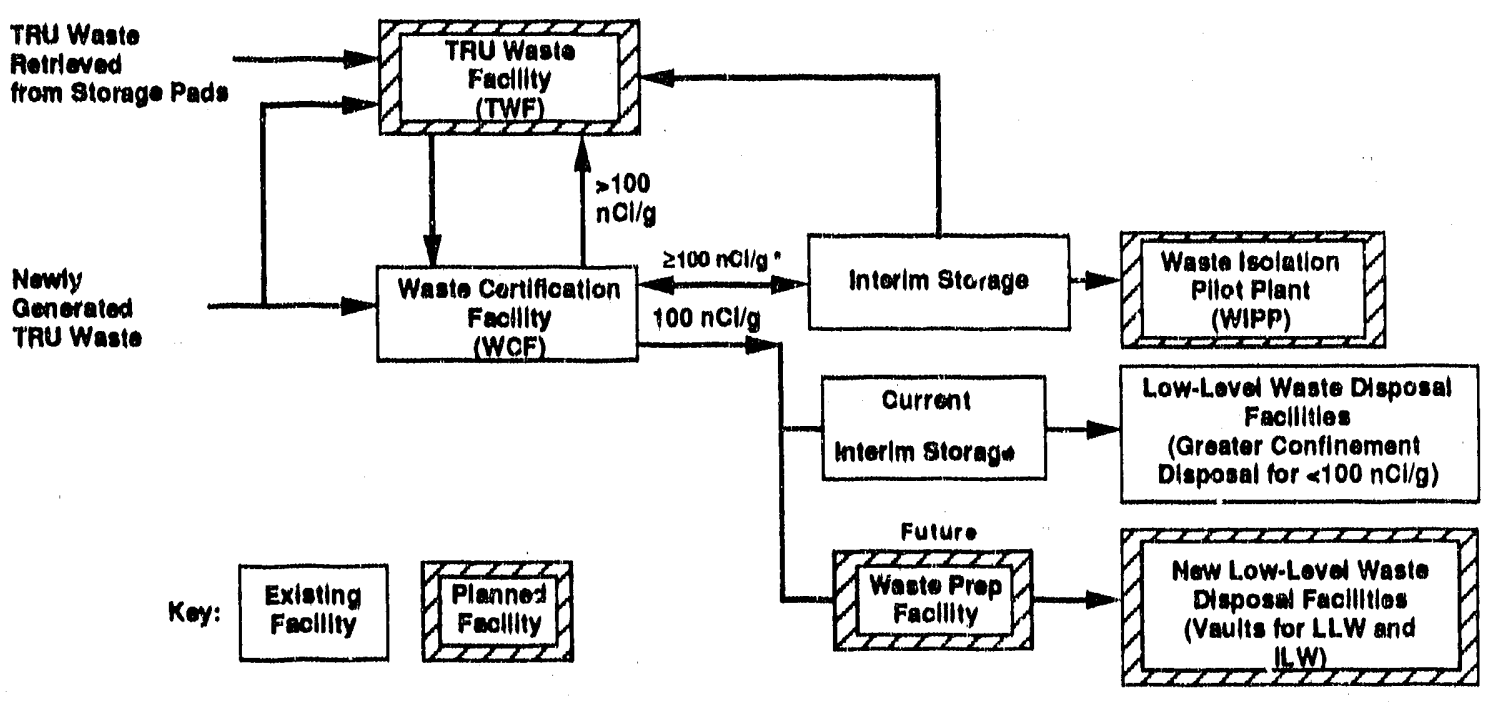

- May also be mixed waste; handling is the same.

M707041

Figure 3.9 Transuranic Waste Management Plan 


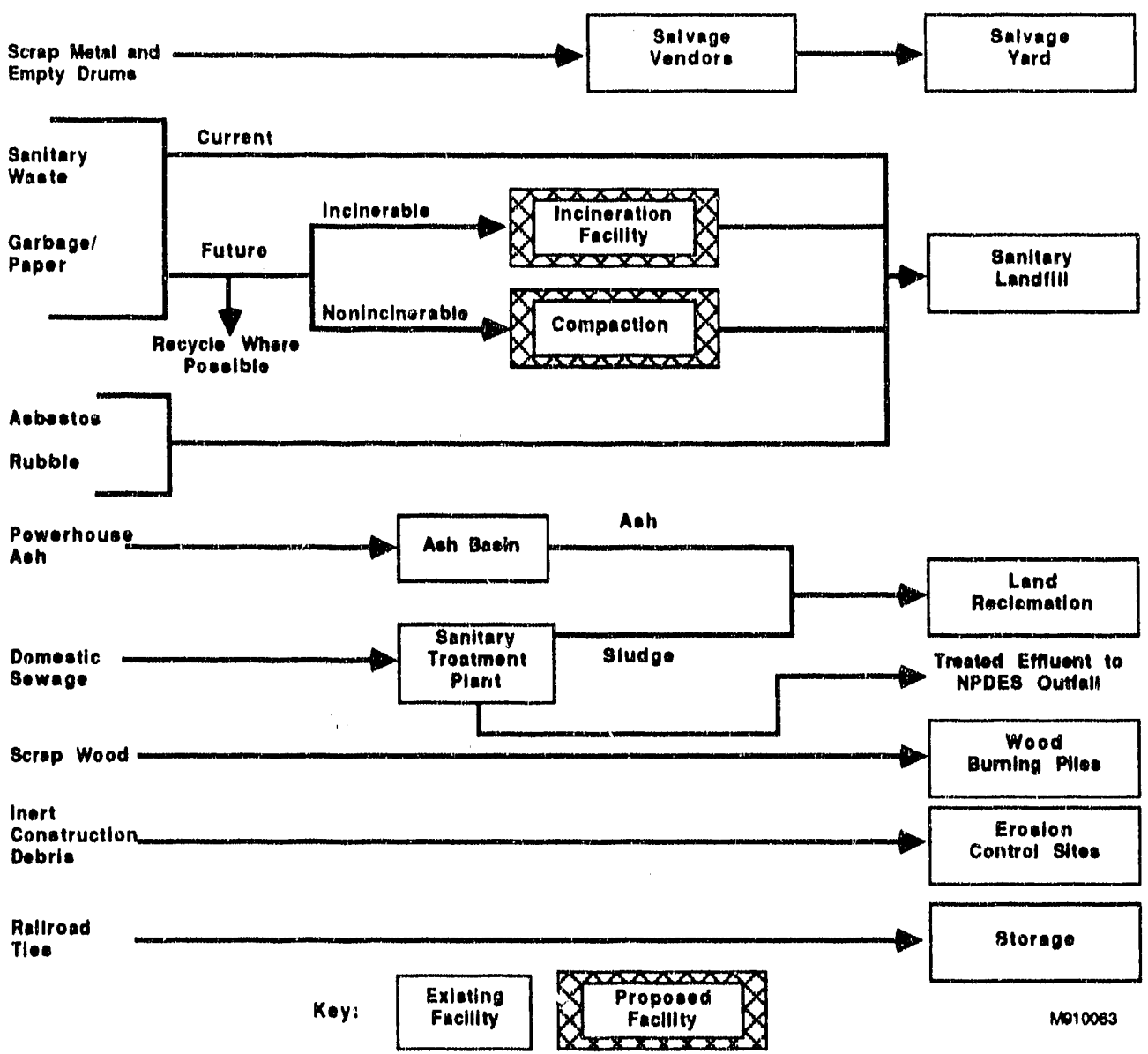

Figure 3.10 Nonradioactive Nonhazardous Waste Management Plan 


\subsection{PRIMARY SITE-SPECIFIC OBJECTIVES BY PROGRAM}

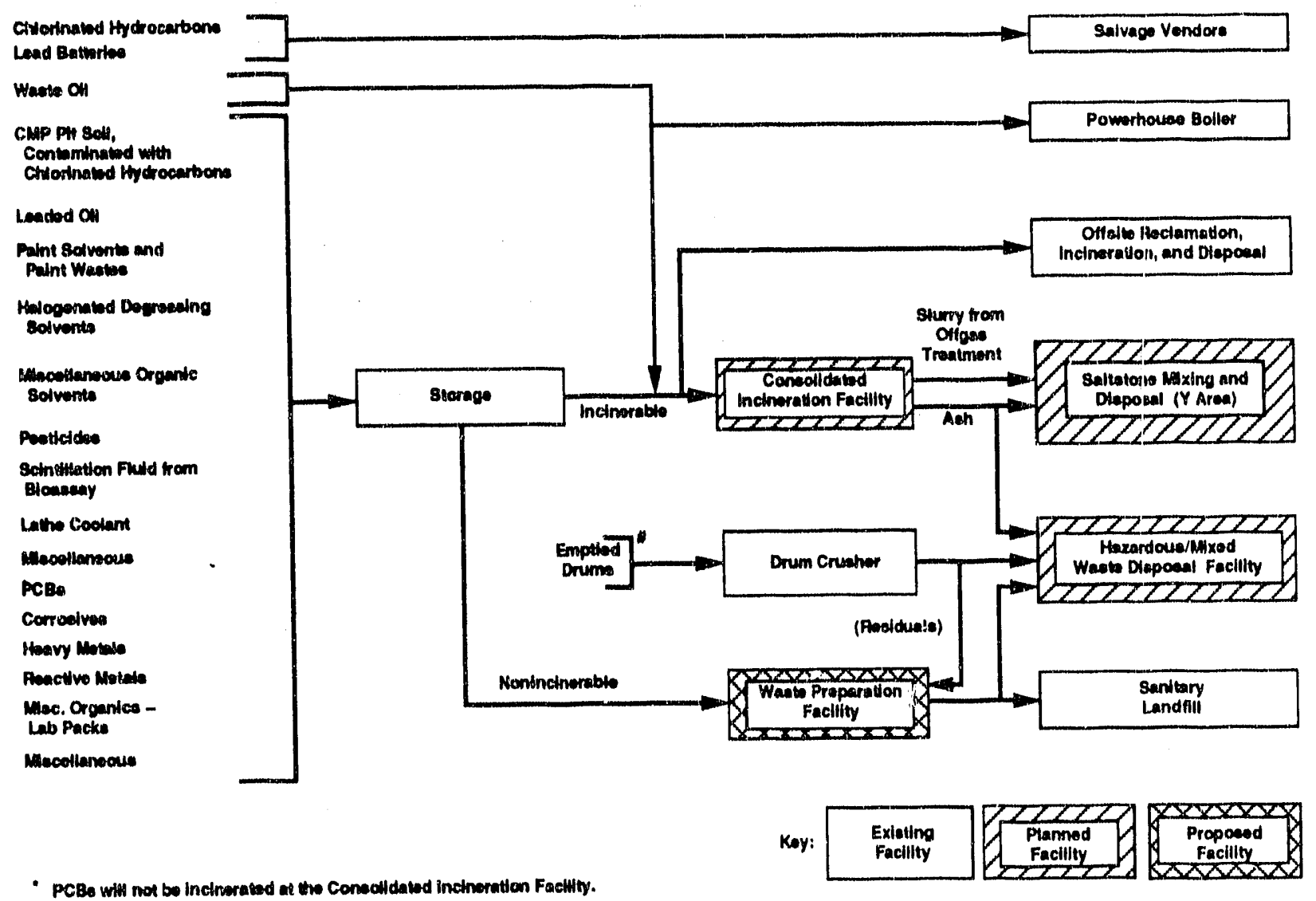

- PCBe with not be inctraraced at the Consolldated inclneration Facilly.

- Theoe druma formerily combalned hazazdous motes.

Figure 3.10 Nonradioactive Nonhazardous Waste Management Plan (Contd) 
WSRC-RP-91-596

SITE SPECIFIC PLAN

3.0 PRIMARY SITE-SPECIFIC OBJECTIVES

BY PROGRAM
Effective 8/1/91

Page 53 of 55

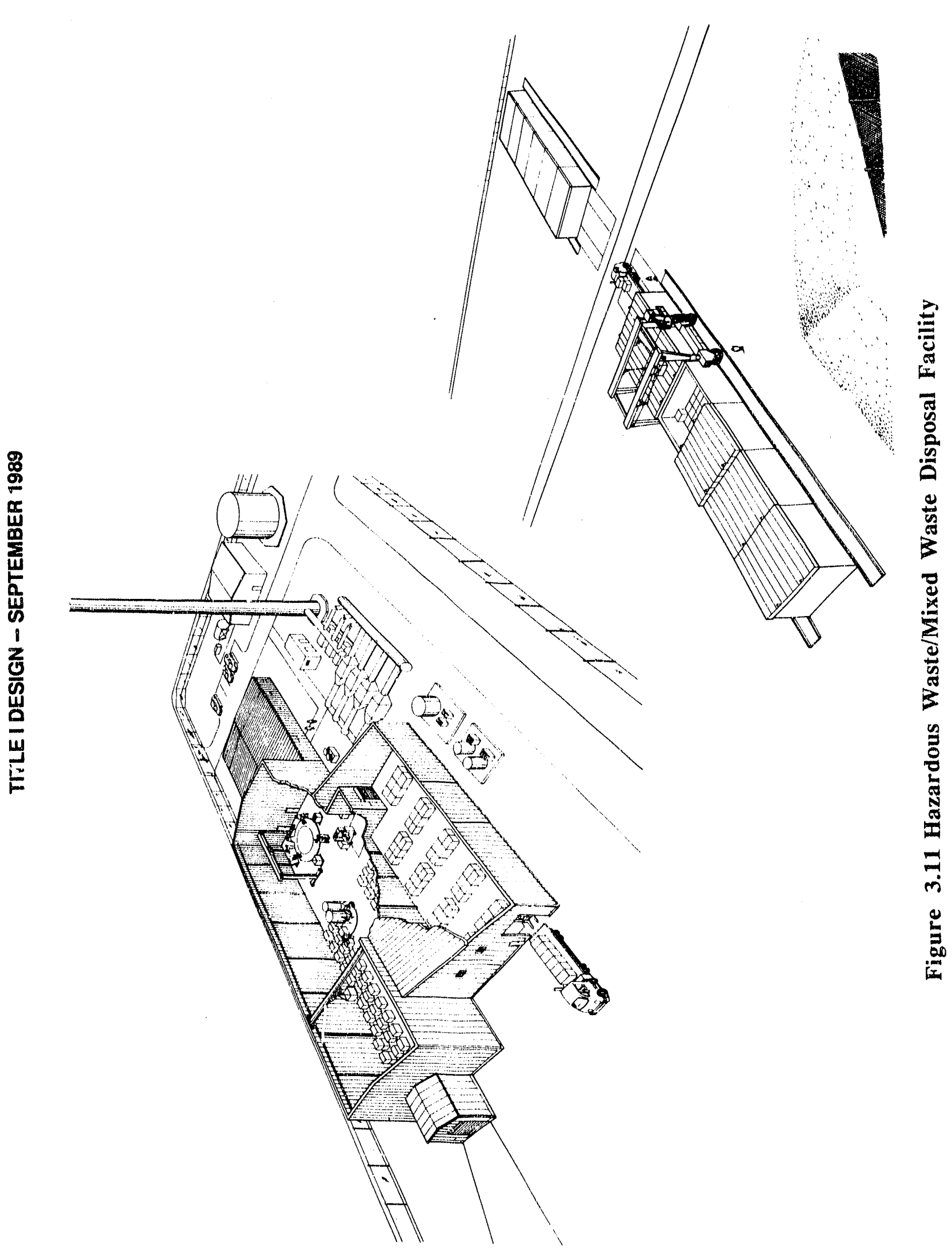




\subsection{PRIMARY SITE-SPECIFIC OBJECTIVES BY PROGRAM}

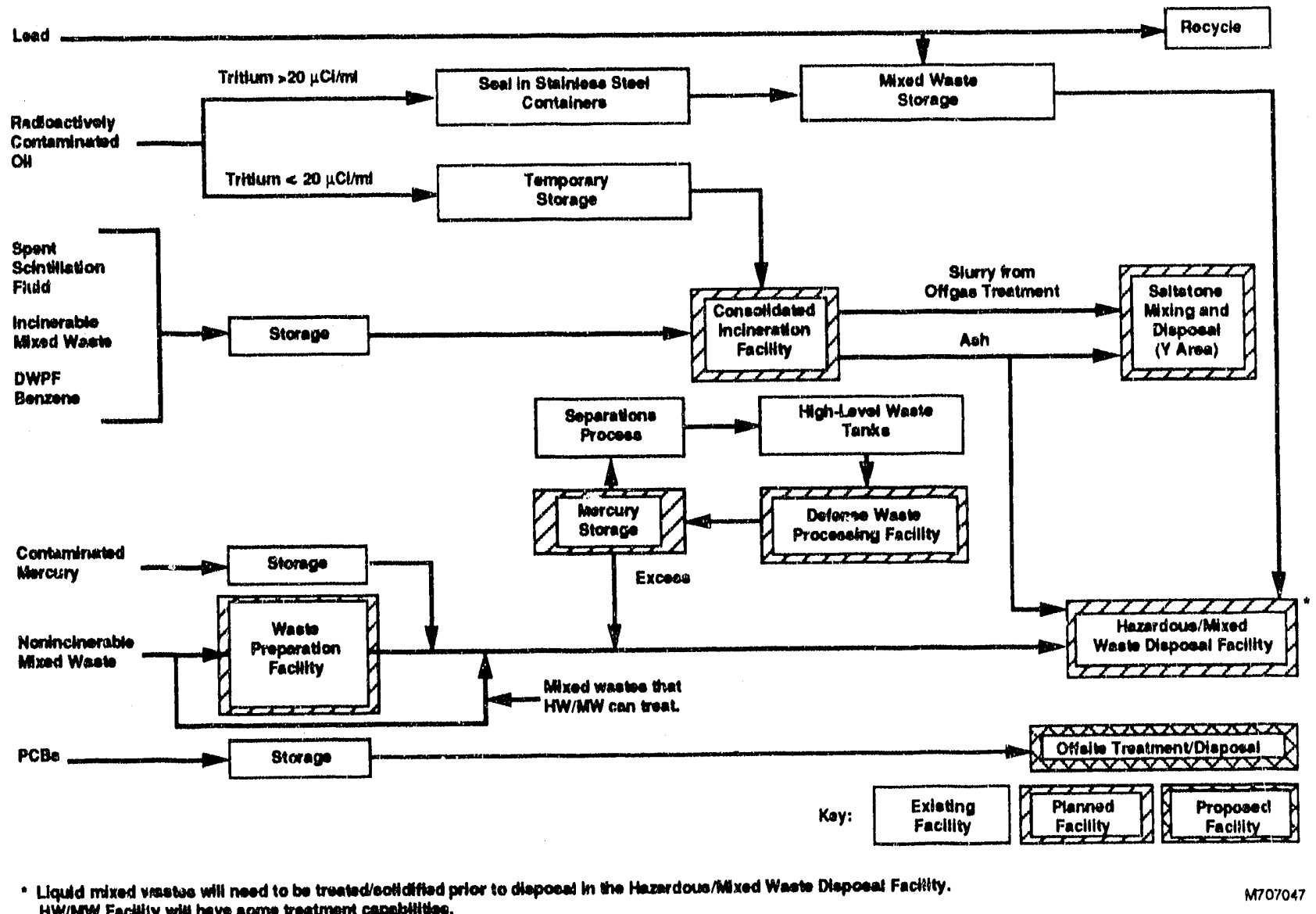
HW/MN Factily will have some treatmem capablltibe.

Figure 3.12 Mixed Waste Management Plan 
WSRC-RP-91-596

Effective 8/1/91

SITE SPECIFIC PLAN

\subsection{PRIMARY SITE-SPECIFIC OBJECTIVES \\ BY PROGRAM}

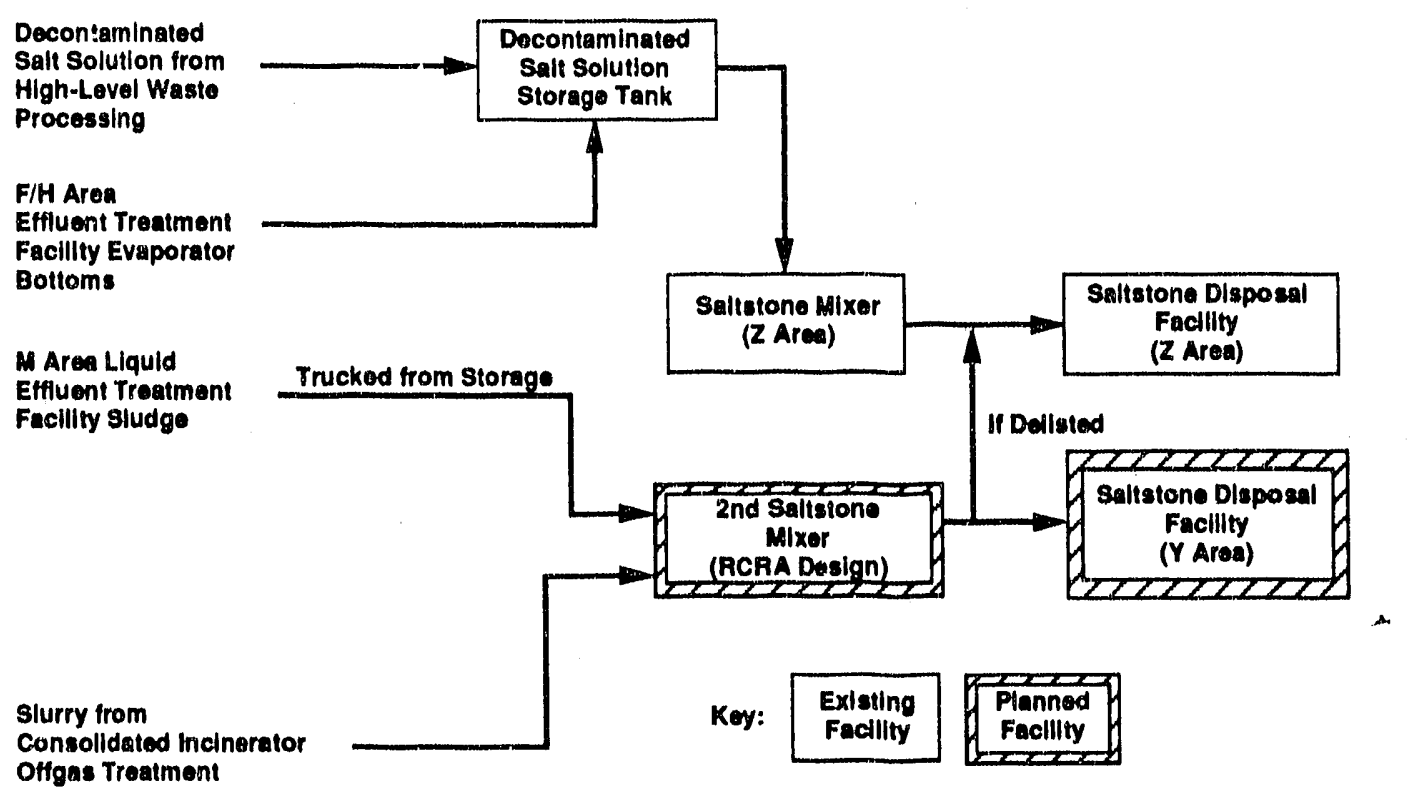

M707042A

Figure 3.13 Savannah River Site Saltstone Disposal Plan 


\section{CONTENTS}

Section 4.0 Major Accomplishments

\section{Page}

4.1 Corrective Activities

4.2 Environmental Restoration

4.3 Waste Management Operations

4.3.1 Power

4.3.2 Reactor Materials

4.3.3 Reactors

4.3.4 Separations

4.3.5 Savannah River Laboratory

4.3.6 Tritium Department

4.3.7 Waste Management

4.3.8 Defense Waste Processing Facility

4.4

Technology Development 


\subsection{MAJOR ACCOMPLISHMENTS}

\subsection{Corrective Activities}

Two major accomplishments have been achieved in Corrective Activities in FY 1991. Only one corrective activity remains to be completed at SRS.

\section{A-008 Outfall}

The 784-A Powerhouse waste streams which previously discharged to effluents and then flowed to A-008 Outfall consist of ash scrubber water, process cooling water, service, and domestic water tank overflows, well blowoff, boiler blowdown, washdown water, and coal unloading sump discharge. The wet ash scrubber discharge and the washdown water contain high levels of suspended solids. Powerhouse wastewater is now collected in a tank, transferred to a tanker truck, and transported to the D-Area ash basin for disposal. A treatment facility will be built to treat these wastes so that they will not be transferred to the D-Area ash basin for disposal.

\section{$\underline{\text { K Reactor Cooling Tower }}$}

The schedule required by the consent order for completing the cooling tower requires the cooling tower to be operational by December 31,1992 . The project is currently on this schedule. Project total estimated cost (TEC) is $\$ 79$ million.

\subsection{Environmental Restoration}

ER accomplishments encompass closures, remediations, and treatment methods. These accomplishments occurred within FY 1991.

\section{M-Area Settling Basin}

The 1.5-acre M-Area Settling Basin was used for disposal of wastewater containing metals, organic solvents, and low-level radioactivity from 1958 through 1985 . Closure consisted of waste stabilization with concrete slurry, placement of a kaolin clay cap, and restoration of the Carolina Bay. A RCRA Part B Permit was issued by SCDHEC and the closure certification statement has been received.

\section{Mixed Waste Management Facility}

A 58-acre site, previously used for disposal of low-level radioactive and hazardous waste from 1972 to 1986 , was closed using dynamic compaction of waste and placement of a kaolin cap. Closure was completed in December 1990 and closure certification has been received. 


\subsection{MAJOR ACCOMPLISHMENTS}

\section{EAH-Areas Seepage Basins}

Seven seepage basins totaling 22 acres were used for the disposal of wastewater containing trace metals, salts and low-level radioactive wastes from 1955 to 1988 . Closure of the FArea Seepage Basin consisted of placement of a kaolin cap with a gravel drainage layer and geotextile fabric. F Area was certified and closed by SCDHEC; $\mathrm{H}$ Area has been closed. SRS is awaiting final certification from SCDHEC.

\section{Metallurgical Laboratory Basin}

The 0.13-acre Metallurgical Laboratory Basin was used for the disposal of waste water containing metals and organic solverits, from 1956 to 1985. Closure consists of dewatering the basin, placement of a kaolin cap, and placement of a drainage layer above a geotextile fabric. Approval by SCDHEC of the program to dispose of basin water is expected in July 1991. Closure completion is expected in FY 1991.

\section{5-C Process Tank and Underground Fuel Storage Tanks (UST)}

The process wastewater and sludge from 105-C. Process Tank has been disposed of by Waste Management Operations. Certification of closure is expected in FY 1991.

\section{SRL Seepage Basins}

Four stepage basins totaling 2.15 acres were used for disposal of low-level radioactive wastewater with trace metals and organics from 1954 to 1982 . Comments from SCDHEC on the Site Assessment Report have been received, and SRS is awaiting comments from Natural Resource Defense Council (NRDC). A program for characterization of the influent piping has been developed. A closure plan for the basin will be developed upon receipt of NRDC comments on the site assessment report. This basin is also in the RCRA 3004 (U)/CERCLA program, and an RFI/RI work plan has been submitted to the EPA.

\section{New TNX Seepage Basin}

An earthen basin totaling 0.43 acre is scheduled to be closed per NRDC Lawsuit Consent Decree. Comments from SCDHEC on the Site Assessment Report have been received, and SRS is awaiting comments from NRDC. A program for characterization of the influent piping has been developed. A closure plan for the basin will be developed upon receipt of NRDC comments on the site assessment report. This basin is also in the RCRA 3004 (U)/CERCLA program, and an RFI/RI work plan has been submitted to the EPA.

\section{Railroad Crosstie Disposal.}

A bioremediation facility is proposed for the disposal of approximately 125,000 used railroad crossties that were used at SRS from the inception of the site. A one- to four-acre covered facility with a small bioreactor for micro-organisms has been proposed. Initial studies indicate excellent decomposition of the creosote using this methodology, after the crossties have been chipped to appropriate decomposition sizes. Completion is expected in FY 1992 if funding is approved in a timely manner. 


\section{Acid/Caustic Basins}

Four basins totaling 0.23 acre were used for the disposal of alternatively high-and low-pH wastewater (dilute sodium hydroxide and sulfuric acid) from 1954 to 1982 . Proposal for a clean closure has been submitted to SCDHEC, and approval is expected by September 1991. Closure would be completed in FY 1992.

\section{Waste Sites Monitoring and Maintenance}

Closure monitoring and maintenance of M-Area Settling Basin, F/H-Areas Seepage Basins, Mixed Waste Management Facility, Metallurgical Laboratory Basin, Acid/Caustic Basins, and other sites as identified will continue each year. This activity ensures the integrity of the remediation efforts.

\section{D\&D Management Efforts And Studies}

A D\&D section has been organized within the ER Department. The section manager was appointed, effective June 1,1991. Staffing is underway. Work to prepare a site D\&D Program Plan has been initiated. A survey of all site facilities is underway to update historical data banks to select facilities to be decommissioned by the year 2010. This data will be included in the D\&D Program Plan.

Technologies needed to decontaminate and decommission major site facilities have been or are underway as follows: Tank 16 sludge removal, the planned decontamination activities of Tank 16, the removal of Building 305-M test pile and the old HB-Line activities. D\&D of the SED I and II facilities and HWCTR are required for initiation in the near term to demonstrate technologies in special laboratories and start up of a large continuing reactors D\&D project.

Past studies have determined the need to D\&D approximately 500 facilities which will shut down and be radiologically contaminated. Additional facilities which will be chemically contaminated need to be added to the list.

\section{A/M-Areas Ground Water Remediation}

The ground water under the $\mathrm{A} / \mathrm{M}$ Areas is being pumped through an air stripper to remove halogenated hydrocarbons to a residual concentration acceptable to the SCDHEC. The remediation program is now in its sixth year and it is currently estimated that the program will continue through the year 2017. An average of 15 to 17 million gallons of water are treated per month. During 1990, the flow rate was increased to 500 gallons per minute. Construction of a Prototype Air Stripper has been completed, and operation is expected in the third quarter of FY 1991.

Characterization has been completed for the southern $\mathrm{A} / \mathrm{M}$ Areas and vadose zone (unsaturated soil above the water table) projects; corrective action plans are being developed. 


\section{E/H-Areas Groundwater Remediation}

The groundwater remediation at the F/H-Areas Seepage Basins will be conducted in conformance with RCRA and a state-approved Post Closure Plan. A Part B Post Closure Care Permit Application was submitted to SCDHEC on December 3, 1990, per the Settlement Agreement. An agreement was obtained form EPA IV and SCDHEC to submit a RCRA/CERCLA Integrated Document by August 30, 1991, to present the SRS preferred alternative.

\subsection{Waste Management Operations}

\subsubsection{Power}

\section{Redesign of Treatment Facility}

High levels of arsenic were discovered in the 784-A Powerhouse ash scrubber water in early 1990. Project S-3072 originally provided for the design of a treatment facility to treat the ash scrubber water, in addition to other powerhouse waste streams, for solids, $\mathrm{pH}$, and temperature. However, studies showed that high arsenic levels would be experienced in the discharge, resulting in unacceptable levels at the outfall. Therefore, the ash scrubber stream has been removed from the treatment scheme. The system is being redesigned to incorporate a baghouse, which will essentially replace the wet ash collection system with a dry system. After the ash is collected in the baghouse, it will be disposed of in the same manner as the filter cake from the treatment facility's clarifier by being sent to an existing ash basin onsite. Since the ash is the bynroduct of a fossil fuel burning power facility, it is categorically excluded from RCRA regulations for arsenic content.

\subsubsection{Reactor Materials}

\section{Interim Treatmen / Storage Facility (IT/SF) Waste Volume Reduction}

A new process was implemented in 1990 to treat the separated supernate layer in the IT/SF tanks in the Dilute Effluent Treatment Facility (DETF). Supernate is processed through the DETF wastewater treatment plant along with the routinely generated wastewaters from $M$ Area. The DETF supernate treatment process is undergoing optimization to increase the amount of supernate which can be handled per batch. Supernate has been increased from an initial 3.3 percent to 7.6 percent per wastewater treatment batch on a volume basis. 85,000 gallons of supernate have been removed from the IT/SF tanks since June 1990. The reduction in the IT/SF tank volumes reduces the volume of material which will require treatment and stabilization and subsequent storage in a hazardous waste disposal facility.

\section{Liquid Effluent'Treatment Facility (LETF) Optimization}

The implementation and optimization of a flocculant agent and the conversion to a coarser grade of filter aid have reduced the quantity of waste filter cake and Filter Paper Take-Up Rolls (FPTUR) generated during the processing of M-Area wastewaters. A 50-percent reduction in the generation of filter cake and an 8-percent reduction in the FPTURs generated for disposal have been realized through the initial process optimization phases. In conjunction, 42 percent less filter aid is required as a result of the process optimization. 


\section{Filter Paper Take-Up Rolls (FPTUR) Waste Compaction}

The compaction of the FPTURs was implemented to reduce the volume of mixed waste generated in M Area. Waste handling procedures and minor equipment modifications were required to allow the compaction of the FPTURs in the Building 313-M waste compactor. The volume of FPTUR waste has been reduced by a factor of 3.5 through compaction.

\subsubsection{Reactors}

\section{Waste Handling Organization}

Reactor Operations has formed a new dedicated waste handling organization. Staffing of this group should be completed by the end of FY 1991.

\subsubsection{Separations}

\section{Waste Generation}

Separations decreased waste generation from its facilities by five percent in FY 1990 compared to FY 1989. Generation in FY 1991 is half of the value forecasted for FY 1991. Also, the facility-specific Waste Minimization Plans were developed and approved in FY 1991 .

\section{Spill Containment}

A project to provide additional spill containment for chemical storage areas of the 211-H facilities was completed in FY 1990. This project supplemented existing structures by providing containment in regulated areas.

\subsubsection{Savannah River Laboratory (SRL)}

The thrust of SRL's research and development activities centers on support for site waste management production operations, solution of production technical problems, and enhancement of existing production processes. The emphasis is on development and demonstration of technology for waste management operations. The majority of these efforts are driven by numerous and diverse new production waste management initiatives. This is accomplished through the use of engineering-scale facilities and laboratories. Primary efforts are currently being undertaken in the areas of High-Level Waste decontamination, High-Level Waste transfer, Low-Level liquids treatment, waste incineration technology, plutorium recovery, Transuranic Waste support, High-Level Waste tank farm support, SRL model waste, salt disposal, new Low-Level Waste disposal systems, waste disposal technology, waste site closure support, decontamination technology, waste solidification, and waste minimization. Specific SRL waste management accomplishments include:

- Process Flowsheets

- DWPF/In-Tank Precipitation (ITP)/Saltstone. 
- Replacement Tritium Facility (RTF)/Replacement Extraction \& Purification Facility (REPF).

- Replacement Tritium Facility (RTF)--Advanced Hydride Laboratory

- Equipment Design

- Robotics/Ashcrete.

- Prototypes--Thermal Cycle Absorption Process (TCAP), Metal Hydride Applications.

- Equipment Run-In

- Waste Tank Pumps.

- Replacement Tritium Facility (RTF) Startup Support.

- Corrosion Protection Data

- Tank Farm.

- Capacity Improvement Recommendations

- Effluent Treatment Facility (ETF)/In-Tank Precipitation (ITP).

- Facility Flowsheets

- TRU Waste Facility (TWF)/Consolidated Incinerator Facility (CIF)/ Effluent Treatment Facility (ETF).

- Replacement Tritium Facility (RTF)/Replacement Extraction \& Purification Facility (REPF).

- Computer Simulations/Modeling

- Groundwater Impacts/Consolidated Incinerator Facility (CIF).

- Thermal Cycle Absorption Process (TCAP).

- Pilot-Scale Demonstrations

- Decontamination/Consolidated Incinerator Facility (CIF).

- Advanced Hydride Laboratory.

- Special Study Coordination

- Engineered Low-Level Trench Dose Evaluation. 
- Process Safety Review Teams

- Operational Readiness Review (ORR)/Startup/Incident.

- Replacement Tritium Facility Operational Readiness Review (RTF ORR), Technical Standards, Process Requirements.

- Technical Studies

- Drum Life/Gas Gieneration.

- Equipment Evaluation

- Tank Nozzle/Effluent Treatment Facility (ETF) Filters.

- Special Chemical Analysis

- In-Tank Precipitation (ITP)/Tank Farm/Effluent Treatment Facility (ETF).

- Weapons Systems Design Coordination

- Process/Equipment Engineering Demonstrations

Precipitate Hydrolysis

- Reactor Fouling: Developed modified Operation Hydroxlamine Nitrate (HAN) to reduce fouling.

- Decanter Performance: Developed recycle process for organics to improve high boiler removal (>90-percent removal of aromatics).

- Identified and defined potential flammability problem in offgas:

(1) Demonstrated safe operating parameters.

(2) Recommended appropriate process safety interlocks to DWPF.

- Modified Process To Accommodate Nitrate Waste Tank Corrosion Inhibitor

Melter Feed/Chemical Process Cell (DWPF)

- Identified hydrogen generation problem during noble metals melter 1/10-scale engineering demonstration:

(1) Define key $\mathrm{H}_{2}$ generation mechanism (In Progress).

(2) Verify that $\mathrm{H}_{2}$ is not a problem prior to DWPF Cold Chemical Runs (In Progress). 
(3) Develop/recommend resolution to $\mathrm{H}_{2}$ flammability.

- Verifying vitrification process for SRS sludges.

(1) Tank 51 demonstration w/o noble metals (Complete).

(2) Tank $51 \mathrm{w} / \mathrm{Hg}$ (Complete - design satisfactory).

(3) Tank $51 \mathrm{w} /$ noble metals $-\mathrm{H}_{2}$.

- Functional testing of melter off-gas system designs, melter drain valve, interim canister closur: ', :hnology.

Waste Form Qualification

- Developed Product Consistency Test (PCT) - adopted a standard for waste glass durebility in the repository program.

- Provided experimental verification of vitrification as "Best Available Techn slogy" for HLW--over 7600 hours of melter feeding time inincluding response to upset.

- Developed first "glass product control program description" according to NRC guidelines.

- Developed feed specifications.

Process Control

- Developed Holledge Gauge to measure slurry level and specific gravity: Improved performance cost improvement $>\$ 3 \mathrm{MM} / \mathrm{yr}$.

- Developed decontamination DWPF samples for organic analysis.

- Identified and demonstrated foam suppressants for DWPF.

- Developed Technical Basis for DWPF Stack Permits.

- Developed Product Composition Control System for DWPF that Provides algorithms (first principles) for product quality and process control.

\subsubsection{Tritium Department}

The Tritium Department's accomplishments for FY 1990 and FY 1991 include the following items: 


\section{FY 1990}

The Tritium Department began compacting low-level job control waste (shoe covers, paper, plastic, gloves, etc.) from Buildings 232-H and 238- $\mathrm{H}$ in May 1990. Waste compaction of Building 234-H low-level job control waste began in August 1990.

Tritium Facilities Waste Minimization Plan was developed and approved by May 1, 1990. Noncompactible low-level waste is put in 12-mil plastic waste bags instead of cardboard boxes, as of September 1990. Tritium Facilities also increased amount of waste that can be loaded into a B-25 burial box.

The Tritium Department improved B-25 burial box accountability. Access is now restricted to empty and loadec B-25 burial boxes. The monthly reporting of B-25s sent tc. Waste Managunent Department for disposal was improved. Charts were developed to track waste generation by process building and waste type.

All Tritium Facilities waste streams were charact srized during August 1990.

\section{FY 1991}

The Tritium Facilities Waste Minimization Plan was revised per SRS Waste Minimization Group guidance. This plan was approved by Tritium Facilities management on March 29, 1991.

\subsubsection{Waste Mianagement}

The following Waste Management accomplishments occu rred between April of 1989 and April of 1991:

\section{Space Gain}

Evaporators have reclaimed 3,463,000 gallons of space in H- and F-Areas tank farms. Space gain is essential if Interim Waste Management is to continue accepting high-level waste generated by nuclear material processing. A finite amount of storage space exists for high-level waste.

\section{Saltstone Startup}

Interim Waste Management supported the startup of Saltstone (Z-Area) by successfully beginning transfers from Tank 50 to Saltstone. Transfers comprise evaporator bottoms from the F/H Effluent Treatment Facility (F/H ETF).

\section{New High-Level Waste Evaporator}

Construction has begun on the New High-Level Waste Evaporator (NHLWE). This evaporator will replace the $1 \mathrm{H}$ evaporator and will provide a greater processing capacity. 


\section{H Concentrate Transfer System}

The H Concentrate Transfer System (CTS) Instrument Panel was relocated from the field to the control room. This will allow constant surveillance of the panel. The H CTS performs the transfer of saltcake from the evaporators to the concentrate tank.

\section{Cooling Towers}

Replacement of cooling towers on the H-Area tank farm New Hill and for the $2 \mathrm{H}$ Evaporator has begun. The current cooling towers have reached their useful lifetime. The new cooling towers will provide better performance for cooling the waste tanks.

\section{Isokinetic Samplers}

The isokinetic samplers are currently being upgraded. These upgrades will provide better sampling capabilities of purge and annulus exhaust air on the waste tanks.

\section{Hydrogen Monitors}

Replacement of hydrogen monitors on $\mathrm{H}$ - and F-Areas tank farm waste tanks has begun. The old monitors required constant maintenance.

\section{$1 \mathrm{H}$ Evaporator Ungrades}

Physical modifications have been completed for the $1 \mathrm{H}$ Evaporator Vent Line to correct a leaking vent line. Functional testing of the CTS ventilation concentrate transfer system and CTS loop transfer: system is completed. Procedure verification is completed. Physical modifications per action items stemming from incident reports is completed. The eyaporator is ready for restart pending resolution and completion of an Operational Readiness Review (ORR).

\section{Solid Waste Disposal Expansion}

Construction has begun on the Solid Waste Disposal Expansion. Projections estimate that current disposal space for low-level radioactive waste will be completely utilized by the summer of 1992 . This project will provide three vaults; a low-activity waste vault, an intermediate-level nontritium vault and an intermediate-level tritium vault. The project will also provide a storage building for storing wastes that contain isotopes with long half-lives.

\section{TRU Pads}

Two TRU pad shelters were constructed over two TRU pads located in E Area. The enclosures were built to prevent rainwater from entering the TRU waste drums.

\section{ETF Processing}

The capacity throughput at the F/H ETF has been increased to approach the design basis. This increase involved improving the Norton Filter system so that the filter performance increased from 20 gallons per minute to 60 gallons per minute. This improvement was 
necessary so that the $\mathrm{F} / \mathrm{H}$ ETF can meet projected flows that will be received from tank farm and canyon operations.

Performance Improvement Plan

A Performance Improvement Plan has been developed. This plan provides detailed schedules and scopes for meeting INPO guidelines in conduct of operations, maintenance, technical, and training.

\section{Waste Minimization Program}

A Waste Minimization Program was implemented sitewide. The purpose of this program is to provide an organized, comprehensive and continual effort to systematically reduce waste generation. The program is designed to eliminate or minimize all forms of wastes generated onsite.

\section{Storm Water Monitors}

Immersed storm water monitors were developed and tested. These monitors achieved a five hundred percent increase in sensitivity over the current storm water monitors. Once the new monitors are installed, contaminated storm water will more effectively be detected and diverted to the F/H ETF.

\section{Blue Dot Program}

A management program called the blue dot program has been developed and implemented. The purpose of this program is to identify containers of products with hazardous ingredients and to minimize or eliminate future use of those products. A chemical coordinator has also been designated for each facility to better manage chemical products.

\subsubsection{Defense Waste Processing Facility}

DWPF's accomplishı,ents for FY 1990 and FY 1991 include:

\section{FY 1990}

The Integrated Water Run Phase of the DWPF Test program began (4QFY90).

The Mechanical Completion Milestone of the Vitrification Building was met (4QFY90).

The Mechanical Completion Milestone of the Salt Processing Cell was met (4QFY90).

The Saltstone Facility began Radioactive Operations (2QFY90).

\section{FY 1991}

The Saltstone Facility successfully completed the Naval Fuels drums disposal project in (3QFY91). 
The Industrial Waste Water Operation Permit for the Vitrification Building was received from SCDHEC in 1QFY91.

Cold Runs Addendum to Waste Water Permit was received in 3QFY91.

The Integrated Water Runs schedule was completed in 3QFY91.

The Industrial Waste Water Permit for the 980-S Cold Chemical Waste Treatment Facility was expected to be received in $4 \mathrm{QFY} 91$.

SCDHEC Glass Waste Storage Building approval was received in 2QFY91.

\subsection{Technology Development}

The following accomplishments occurred in FY 1990 and FY 1991:

\section{EY 1990}

- State-of-the-art decontamination and robotics technology was evaluated for implementation at SRS and other DOE sites .

- An improved modeling technique for groundwater flow and contaminant transport for SRS waste management facilities was developed.

- Thermal and chemical processes aimed at reducing TRU waste generation by TI recovery of TRU isotopes from the process residues were evaluated.

- Development of hazardous and mixed waste (H\&MW) treatment technologies for disposal of H\&MW in compliance with EPA regulations was begun.

- Evaluation of electrolytic oxidation for destruction of hazardous organic waste aimed at future application for mixed waste was begun.

- Evaluation of methods for certifying HEPA filters as meeting the WIPP Waste Acceptance criteria was begun .

- Differential scanning calorimetry experiment showing acceptable heat generation rates for the epoxy encapsulation of HEPA filters was completed.

- The environmental behavior of C-14 and Np-237 disposed of in shallow land buria! trenches was characterized.

- Evaluation of alternatives to CFCs for degreasing of fuel rods and target assemblies was completed.

- Specifications were developed, and an order $k$ as placed for an Inductively Coupled Plasma Mass Spectrometer (ICP/MS) for measurement of trace long-lived radionuclides and hazardous metals in environmental effluents. 
- A program for removing tritium from aqueous waste streams and groundwater was developed.

- A development program for an environmental project for in-situ bioreclamation for cleanup of shallow subsurface contamination was begun.

- Technical support for developing regulatory compliance needs for SRS waste management facilities was provided. This effort is aimed toward characterizing the chemical and physical aspects of the aquifer and the ground water within the aquifers, the lateral and vertical extent of the various aquifers and aquitards, flow rates and flow paths for the groundwater in the various aquifers, and site seismology. The basic hydrogeologic data will be used in modeling studies to evaluate the effectiveness of closure/remedial measures proposed for various waste management facilities. The data are integral to risk assessment analyses. Geologic investigations as to the nature of faults underlying the site are underway. The relationships between the faults and seismologic activities in the area are under investigation. A sitewide seismologic network has been set up and is monitored to increase our understanding of the nature of seismic waves generated by earthquakes in the region. A study of the effect of coal piles on groundwater quality has also been initiated, because a number of coal-fired power facilities exist or have existed at SRS and are known to have impacted groundwater quality.

- Specifications were developed, and purchase requirements were initiated for highsensitivity gas chromatograph mass spectrometer to detect ultra trace organics and degradation products released to the environment from present production operations.

- Development of a TRU waste form began to ensure that high-specific activity waste meets shipping and disposal requirements for the Waste Isolation Pilot Plant (WIPP).

- A program was developed for international technology transfer with other DOE complex waste management and environmental remediation WM\&ER programs; technical exchange with international agencies involved in WM\&ER programs, under bilateral agreements with the DOE; technical liaison with Federal agencies active in radioactive waste regulations and repository programs; and technical liaison with peer review panels that are engaged in DWPF waste acceptance and quality assurance reviews.

- An education outreach program was developed and implemented to provide educational opportunities and career counseling to economically or educationally disadvantaged or minority students and to guide them toward careers in environmental restoration and waste management.

- DOE-EM at HQ was assisted in the planning and implementation of an aggressive education program covering all sectors of technical education.

- An integrated technology demonstration project was developed and implemented to develop:

- new methods for in situ remediation of groundwater and soils 
- related technologies that can assist in environmental restoration activities.

Inparticular, potential applications of directional drilling (horizontal wells) as a delivery/extraction system for subsurface remediation was tested.

- In situ air stripping, a process that combines vapor extraction and air injection, to remove solvents from subsurface soils was demonstrated. Over 4000 pounds of VOCs were removed.

- A consortium of major universities in South Carolina, called the South Carolina Universities Research and Education Foundation (SCUREF), was formed to address ER/WM issues through programmatic research efforts and through the education of the next generation of scientists, engineers, and technologists required to meet the state and nation's needs for sound technical solutions to ER/WM problems.

- A program was developed at SRS in support of DOE-HQ EM robotics technology development initiatives.

\section{FY 1991}

- A report on recommended treatment technologies for hazardous and mixed waste streams for the SR Hazardous Waste/Mixed Waste Disposal Tacility was completed and issued.

- A computer code was developed and implemented to evaluate catalytic exchange of tritium in aqueous waste streams.

- Training for volunteer mentors at the Ruth Patrick Science Education Center at USCAiken, SC was completed. An order for Math Excellence Workshop at Clemson University was also completed.

- Innovative directional drilling technologies using downhole mud motors were evaluated, and post-characterization drilling at the SR Integrated Demonstration (ID) horizontal well site was initiated. The project management plan for the Savannah River ID was issued.

- Effects of TCE in sterile soils and plants was completed.

- Dr. Frank L. Parker received the first distinguished scientist appointment sponsored by DOE and South Carolina Universities Research and Educational Foundation (SCUREF) at Clemson University. 


\section{CONTENTS}

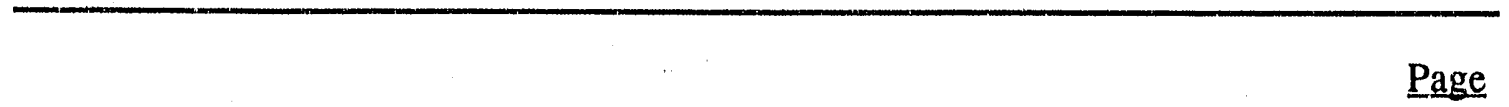

Section 5.0 Funding Summary Description

TABLE

5.1 Savannah River Site Funding Summary FY 1991-1997

FIGURES

5.1 Funding Trends FY 1991-1997

3

5.2 Cost Breakdown FY 1991-1997 


\subsection{FUNDING SUMMARY DESCRIPTION}

Table 5.1 and Figures 5.1 and 5.2 summarize funding for FY 1991 through FY 1997 as reported in the Environmental Restoration and Waste Management Five-Year Plan, Fiscal Years 1993-1997.

- The FY 1991 funding numbers reflect funding at the Congressional Appropriation level at the same time the Five-Year Plan was developed.

- The FY 1992 funding numbers reflect the Executive Branch's funding level request to Congress for FY 1992 at the same time the Five-Year Plan was developed.

- The FY 1993-1997 numbers are at two separate case levels. PUC reflects funding levels at full requirements, constrained only by infrastructure and growth constraints. VTL is a derived budget which reflects potential fiscal restraints of the Omnibus Budget Reconciliation Act of 1990. 


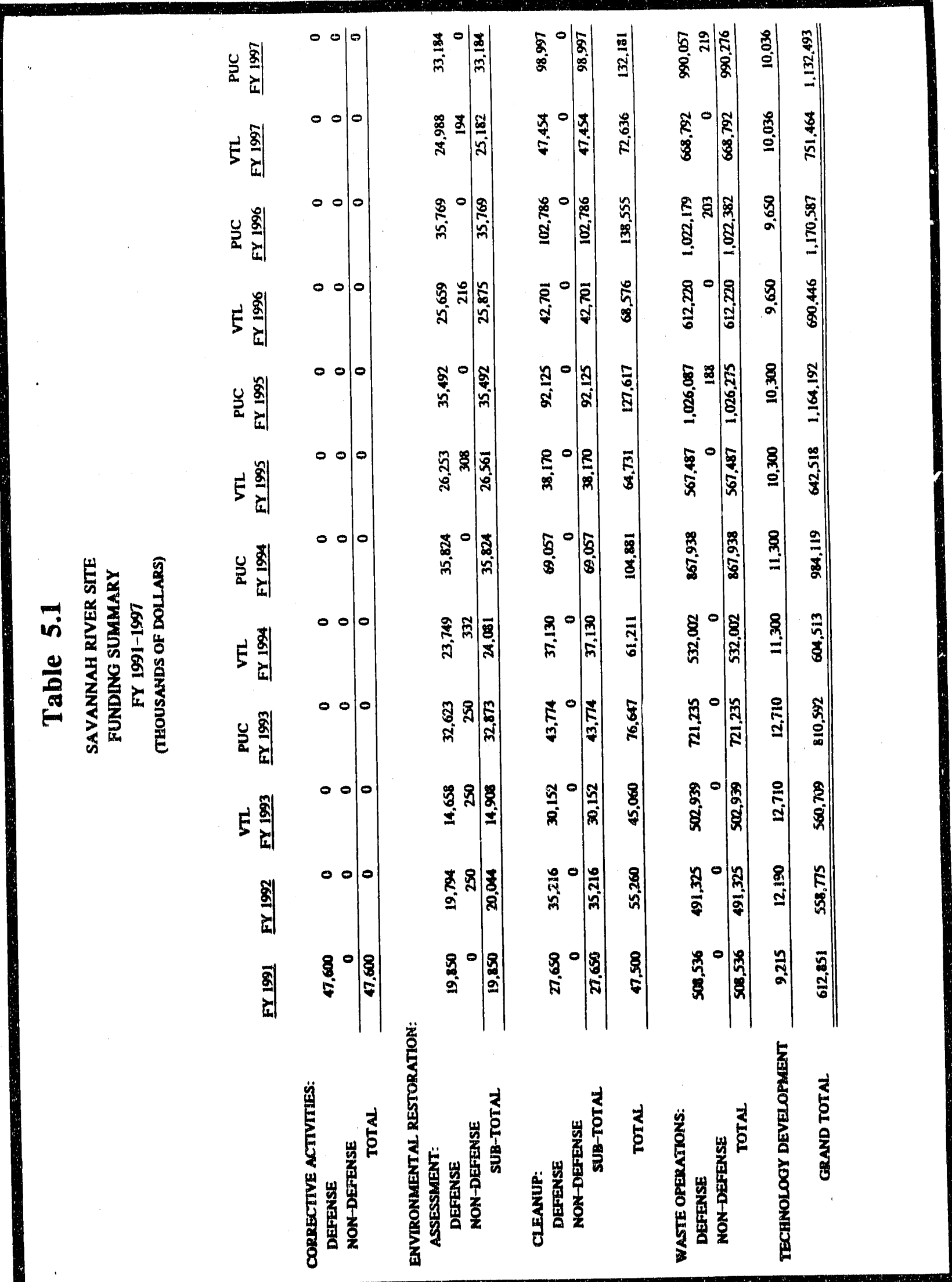




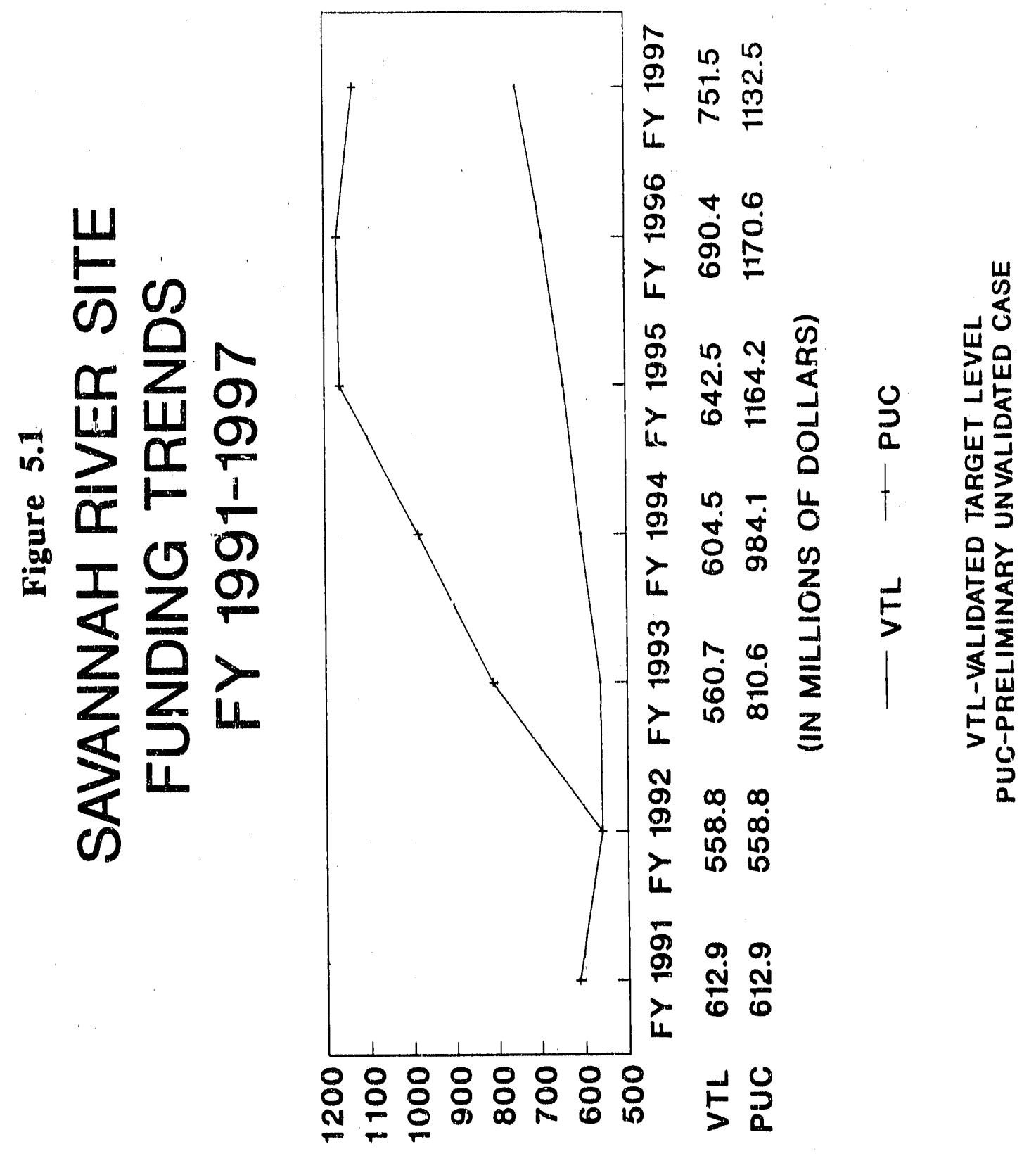




\subsection{FUNDING SUMMARY DESCRIPTION}
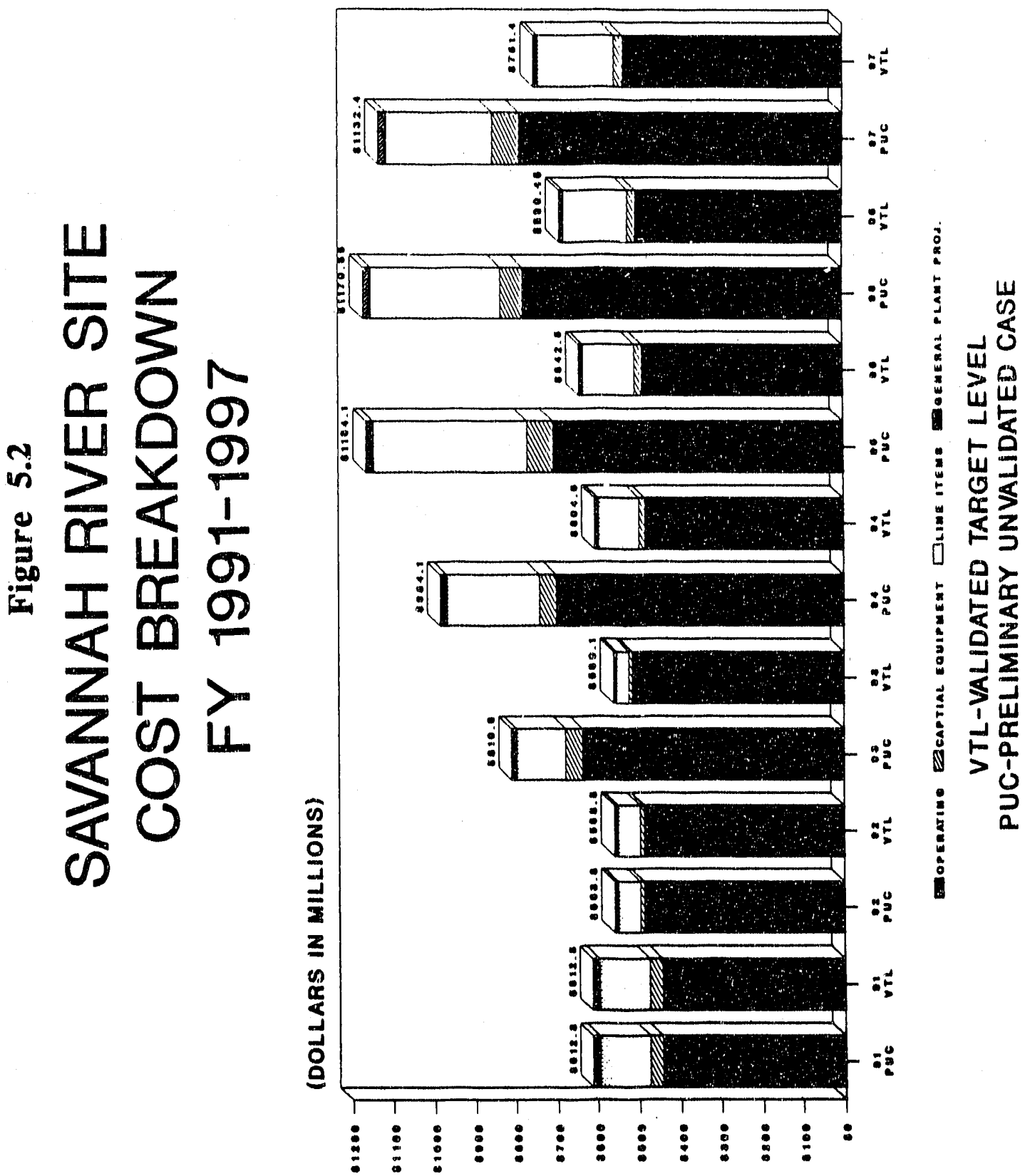
WSRC-RP-91-596

Effective 8/1/91

SITE SPECIFIC PLAN

CONTENTS

\section{CONTENTS}
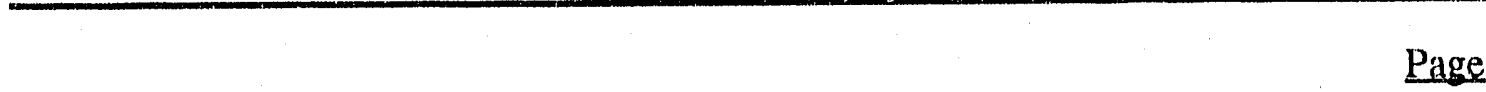

Section 6.0 Milestones

TABLE

6.1 .Milestones 


\subsection{MILESTONES}

The SRS annually reviews its waste management and environmental restoration needs and prepares forecasts and schedules for ensuring that continuous, safe operations are maintained. These forecasts and schedules become the basis for milestones. The schedules begin with a forecast of site needs for waste storage, treatment, or disposal. Based on these needs, projects are proposed and schedules are developed to guide the projects to a timely completion. These schedules and milestones may change depending on final program guidance from DOE-HQ. This section presents the major milestones and schedules taken from the PUC Plan presented in the FYP activity packages.

\section{Table 6.1 Milestones}

Milestone Tirle

\section{Technology Development Division}

Hazardous and Mixed Waste Treatment

Technology Development

Savannah River Laboratory TRU Waste Treatment

Aqueous Detritiation Technology Development

TCE Biodegradation Demonstration Technology Development

Integrated Demonstration for Cleanup of Organics in Soils and at Non-Arid Sites; Phase 2 Bioremediation Tasks

Savannah River Site Integrated Demonstration; Directional Drilling and Characterization

Integrated Demonstration for Cleanup of Organics in Soils and at Non-Arid Sites; Offgas Treatment
Due Date

$9 / 91$

$3 / 92$

$1 / 92$

$3 / 92$

$9 / 92$

$9 / 91$

$8 / 92$
Status

Issue program plan for the treatment development of the Consolidated Incineration Facility blowdown.

Evaluate solidification processes to stabilize sludges and eliminate free liquids.

Complete technology evaluations (Phase 1).

Complete laboratory testing and evaluation of combined anaerobic/ aerobic bioreactor combinations to increase rates and allow better PCE degradation.

Complete or continue first injection campaign by $10 / 91$. Evaluate other nutrients campaign by $9 / 92$.

Complete drilling and installation of test wells.

Complete technologies evaluation reports. 


\subsection{MILESTONES}

Table 6.1 Milestones (Cont'd)

Milestone Title

Due Date

Status

Waste Management

Recovery of 2.5-Million Gallons of Space in F- and H-Area Evaporators

95\% Certification of Newly Generated Drummed TRU Waste

Startup of Consolidate Incineration Facility

Startup of HW/MW Vault Construction

Begin In-Tank Precipitation (ITP) Operations

Resume Processing of First Batch of Sludge for the Defense Waste Processing Facility (DWPF)

Begin Operation of HDB-8 (New Waste Transfer) $7 / 92$

$9 / 91$

$9 / 91$

$10 / 93$

$11 / 92$

$1 / 92$

$9 / 92$
Goal has been changed to 1.0 million gallons. 766,000 gallons of space gain has been achieved through May 1991.

Through May 1991, 99 percent certification was achieved.

Startup delayed due to pending RCRA permits and siting criteria. SC has new siting criteria, one of which is seismic. This requirement is currently under negotiation. A new schedule is being developed to begin construction 2QFY92 and finish construction in 4QFY93.

RCRA Part B Permit application submitted to SCDHEC for review.

Upon revalidation, the schedule for this activity is delayed for the schedule presented in the 1990 FiveYear Plan. Delays resulted from funding restrictions and checkout delays.

Preliminary schedule. Funding and resource limitations may impact this schedule in FY 1992.

This assumes FY 1991 reprogramming of funds is accomplished. The due date is $5 / 93$. 
Table 6.1 Milestones (Cont'd)

Milestone Title

Due Date

Status

\title{
Defense Waste Processing
}

Facility (DWPF)

Hot Startup of DWPF*

$2 / 93$

Current schedule is being revisited. Up grade of the current schedule is in progress with a new Hot Startup date to be determined by that process.

Startup of Y-Area Radioactive

Project is on schedule. Operations*

\author{
Reactor Materials \\ Inspection of Existing Process Sewer \\ Repair of Existing Process Sewer \\ Completion of Construction Project \\ S-2366 (Replace portion of Process \\ Sewer for $320 \mathrm{M}$ and $321 \mathrm{M}$ )
}

$12 / 90$

$6 / 92$

Inspection was completed 12/90.

Vendor procurement bid package is being prepared (revised Tiger Team (TT) cornmitment date is $9 / 92$ ).

Identification of Toxicity of M-Area Waste Waters Achieved

Project was cancelled to consolidate all M-Area process sewer upgrades into a single FY 95 line item project. Functional Performance Requirement document under development (revised TT commitment date of $10 / 95$ to start).

Completion of Modifications to Current Degreaser System

Design of 322-M and 313-M Process Sewers

Completion of initial scouting tests.

Performing alternate processing screening evaluations.

Project was cancelled to consolidate all M-Area process sewer upgrades into a single FY 95 line item project. Functional Performance Requirement document under development (revised TT commitment date of 10/95 to start).

Implementation of Toxicity Reduction Completion of initial scouting tests.

\footnotetext{
* Milestone in PUC but not in VTL.
} 


\subsection{MILESTONES}

Table 6.1 Milestones (Contd)

Milestone Title

Reactor Materials (Contd)

Completion of Modifications to Existing 10/95

Storm Sewer

Completion of Construction (322-M

$\mathrm{OH}$ Process Sewer)

Startup of Construction of 322-M

Process Sewer

Completion of Construction (313-M

OH Process Sewer)

Begin Implementation of Compliance Programs to Reduce Toxicity of Waste Water

\section{Separations}

\section{Completion of Design of Waste} Handling Facilities

Completion of Construction of Waste Handling Facilities*

Startup of Construction**
Due Date

Status

$12 / 95$

$4 / 96$

$12 / 97$

$10 / 99$

$1 / 97$

$9 / 99$

$4 / 97$
Project scope and schedule are being developed.

Project was cancelled to consolidate all M-Area process sewer upgrades into a single FY 95 line item project. Functional Performance Requirement document under development (revised TT commitment date of 10/95 to start).

Project was cancelled to consolidate all M-Area process sewer upgrades into a single FY 95 line item project. Functional Performance Requirement document under development (revised TT commitment date of $10 / 95$ to start).

Project was cancelled to consolidate all M-Area process sewer upgrades into a single FY 95 line item project. Functional Performance Requirement document under development (revised TT comritment date of $10 / 95$ to start).

Completion of initial scouting tests.

Work on conceptual design reports has begun.

Construction is scheduled to begin in 1997.

Construction is to begin in 1994.

* Milestone in PUC but not in VTL.

** Milestone in VTL but not in PUC. 
Table 6.1 Milestones (Contd)

Milestone Title

Reactor

Startup of Design on Underground Fuel Oil Storage Tanks*

Draft Waste Minimization Action Plans

Characterization of Baseline Waste

Selection of Target Waste to Minimize $\because$

Implementation of Minimization Projects

Conduct Baseline Waste Inventory

Completion of Construction on Underground Fuel Oil Storage Tanks*

NMPD.-Waste Management

Accreditation of Personnel Training Program

Renewal of Accreditation for Personnel Training Program*

Accreditation of Maintenance Personnel Training Plan *

\section{Environmental Restoration}

Completion of Closure of MWMF*

Completion of Closure of F-Area Seepage Basin*

* Milestone in PUC but not in VTL.
Due Date

Status

$10 / 93$

Project is in development stage.

$6 / 91$

$7 / 91$

$6 / 91$

$9 / 91$

$12 / 91$

$12 / 98$

$4 / 93$

7/97

$7 / 97$

$12 / 90$

Closure was certified in May.

$1 / 91$
Program is on schedule. The analysis, design and developstage was completed.

Work has not begun. Work on the accreditation program is being implemented at this time.

Work has not begun. Work on the accreditation program is being implemented at this time.

F-Area Seepage Basin was closed January 4, 1991. Certification of closure was in May. 


\subsection{MILESTONES}

Table 6.1 Milestones (Contd)

Milestone Title

\section{Environmental Restoration \\ Completion of Closure of H-Area Seepage Basin*}

Completion of closure of Acid/Caustic Basins*

Development and Submittal of 45

Workplans to EPA*

Completion of Closure of SRL Seepage Basins*

Completion of Closure of New TNX Seepage Basins*

\section{Environmental Protection}

Completion of K-Reactor Cooling Tower

Completion of Overflow Basin Liner

Completion of Construction on Underground Fuel Oil Storage Tanks*

Completion of L-Area Shore Line Sloping

Completion of L-Area Lake Inlet Channel Weir

Completion of Upgrade of L-Area Temperature Monitor
Due Date

(Cont'd)

$8 / 91$

$12 / 91$

$9 / 92$

$11 / 92$

$1 / 93$

$12 / 31 / 92$

$7 / 91$

$12 / 98$

$12 / 92$

$5 / 93$

$8 / 91$
H-Area Seepage Basin was closed May 31, 1991.

Proposal for closure was submitted to SCDHEC.

Twenty-two workplans were completed. Five additional workplans will be completed this year.

Work is ongoing.

Draft functional Requirement document is being reviewed.

On schedule.

Construction is being completed. Package is being prepared for turnover.

Design work to begin 9/30/97.

Project is in design.

Design is in initiation phase. Letter of Instruction was transmitted to Engineering and Project Division.

Evaluation was completed in January 1991. It was determined that temperature monitors were not needed.

* Milestone in PUC but not in VTL. 


\title{
CONTENTS
}

\author{
Section 7.0 References
}

\section{Page}




\subsection{REFERENCES}

EY93 Five-Year Plan Environmental Restoration and Waste Management Activity Data Sheet Summary Report and Data Sheets (May 16, 1991).

M. E. Gorden. Savannah River Solid Waste Forecast--FY91. Report WSRC-RP-90-733, Westinghouse Savannah River Company, Aiken, S. C. (January 1991).

W. C. Miles, Jr. Eunctional Performance Requirements for Interim Sanitary Landfill, Rev. 1. Report NMP-WMP-91-3253, Westinghouse Savannah River Company, Aiken, S. C. (March 8, 1991).

T. E. Pate. Savannah River Site Radioactive Liquid Waste Forecast--1990. Report WSRC-RP-90-589, Westinghouse Savannah River Company, Aiken, S. C. (June 1990).

Sanitary Landfill Groundwater Quality Assessment Plan. Report WSRC-TR-167, Westinghouse Savannah River Company, Aiken, S. C. (June 1990).

Savannah River Waste Management Program Plan--FY 1990. Report DOE/SR-WM-90-1, Department of Energy, Savannah River Operations, Aiken, S. C. (December 1989).

Site Specific Plan--FY90. Report WSRC-RP-90-978. Westinghouse Savannah River Company, Aiken, S. C. (March 4, 1990). 
DATE FILMED 5101192 


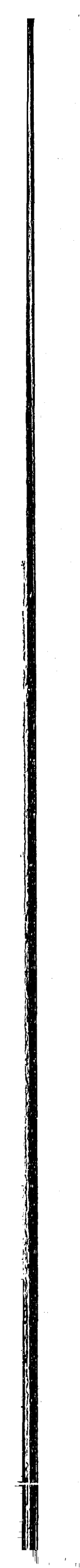

